\title{
Hidden miners - the roles of cover crops and soil microorganisms in phosphorus cycling through agroecosystems
}

\author{
Moritz Hallama (D) - Carola Pekrun • Hans Lambers • \\ Ellen Kandeler
}

Received: 27 April 2018 / Accepted: 6 September 2018 / Published online: 27 October 2018

(C) The Author(s) 2018

\begin{abstract}
Background Phosphorus $(\mathrm{P})$ is a limiting nutrient in many agroecosystems and costly fertilizer inputs can cause negative environmental impacts. Cover crops constitute a promising management option for sustainable intensification of agriculture. However, their interactions with the soil microbial community, which is a key driver of $\mathrm{P}$ cycling, and their effects on the following crop, have not yet been systematically assessed.

Scope We conducted a meta-analysis of published field studies on cover crops and P cycling, focusing on plantmicrobe interactions.

Conclusions We describe several distinct, simultaneous mechanisms of $\mathrm{P}$ benefits for the main crop.
\end{abstract}

Responsible Editor: Ismail Cakmak

Electronic supplementary material The online version of this article (https://doi.org/10.1007/s11104-018-3810-7) contains supplementary material, which is available to authorized users.

M. Hallama $(\bowtie) \cdot$ E. Kandeler

Soil Biology Department, Institute of Soil Science and Land Evaluation, University of Hohenheim, Emil-Wolff-Strasse 27, Stuttgart 70599, Germany

e-mail: hallama@uni-hohenheim.de

C. Pekrun

Agronomy Section, Institute of Applied Agriculture,

Nuertingen-Geislingen University, Neckarsteige 6-10,

72622 Nürtingen, Germany

H. Lambers

School of Biological Sciences and Institute of Agriculture, University of Western Australia, 35 Stirling Highway, Crawley (Perth), WA 6009, Australia
Decomposition dynamics, governed by $\mathrm{P}$ concentration, are critical for the transfer of $\mathrm{P}$ from cover crop residues to the main crop. Cover crops may enhance the soil microbial community by providing a legacy of increased mycorrhizal abundance, microbial biomass $\mathrm{P}$, and phosphatase activity. Cover crops are generally most effective in systems low in available $\mathrm{P}$, and may access 'unavailable' $\mathrm{P}$ pools. However, their effects on $\mathrm{P}$ availability are difficult to detect by standard soil P tests, except for increases after the use of Lupinus sp. Agricultural management (i.e. cover crop species selection, tillage, fertilization) can improve cover crop effects. In summary, cover cropping has the potential to tighten nutrient cycling in agricultural systems under different conditions, increasing crop P nutrition and yield.

Keywords Conservation agriculture $\cdot$ Nutrient cycling · Plant-microbial interactions · Sustainable agriculture · Sustainable intensification $\cdot$ P-mobilization $\cdot$ Soil improving cropping systems

$\begin{array}{ll}\text { Abbreviations } \\ \mathrm{Al} & \text { Aluminium } \\ \mathrm{Ca} & \text { Calcium } \\ \mathrm{Fe} & \text { Iron } \\ \mathrm{K} & \text { Potassium } \\ \mathrm{Mg} & \text { Magnesium } \\ \mathrm{Mn} & \text { Manganese } \\ \mathrm{N} & \text { Nitrogen } \\ \mathrm{P} & \text { Phosphorus } \\ \mathrm{P}_{\mathrm{a}} & \text { Plant-available phosphorus } \\ \mathrm{P}_{\mathrm{i}} & \text { Inorganic phosphorus (orthophosphate) }\end{array}$


$\mathrm{P}_{\text {mic }} \quad$ Soil microbial phosphorus

$\mathrm{P}_{\text {org }} \quad$ Organic phosphorus

$\mathrm{P}_{\mathrm{t}} \quad$ Soil total phosphorus

S Sulfur

SOM Soil organic matter

Zn Zinc

\section{Introduction}

Essential for agricultural production, but often limiting, mineable reserves of phosphorus $(\mathrm{P})$ are non-renewable and concentrated in regions with territorial conflicts, adding a geopolitical dimension to $\mathrm{P}$ scarcity (Cordell and White 2014). Furthermore, $P$ losses via erosion and leaching are responsible for eutrophication of water bodies and ecosystem degradation (Schoumans et al. 2014). Therefore, reliance on costly P-fertilizer inputs poses a threat to food security. Soil-improving cropping systems such as cover crops and conservation tillage are gaining attention for their potential to enhance overall sustainability of agriculture and P management (Tonitto et al. 2006; Simpson et al. 2011; Scopel et al. 2013; Damon et al. 2014). They play an increasingly important role with respect to the concept of ecological intensification (Bommarco et al. 2013) and agroecology (Altieri 2002; Faucon et al. 2017).

Phosphorus-containing fertilizers are used extensively, but the processes underlying the biogeochemical $\mathrm{P}$ cycle are thus far not fully understood (Bünemann et al. 2011), especially under conditions of low $\mathrm{P}$ availability (Clarkson 1985; George et al. 2018). Phosphorus is present in soils in both mineral and organic forms with vastly different degrees of availability; only very small amounts of inorganic $\mathrm{P}\left(\mathrm{P}_{\mathrm{i}}\right)$ are present in the soil solution (Pierre and Parker 1927), and this is the form taken up by plants. In agricultural soils, the soil microbial community is increasingly acknowledged as the principal driver of soil $\mathrm{P}$ dynamics (Bünemann et al. 2011; Richardson and Simpson 2011), and efforts have been made to include soil microbes into $\mathrm{P}$ cycling models (Rengel 2008; Hinsinger et al. 2011; Damon et al. 2014). The relatively large pools of soil organic $\mathrm{P}\left(\mathrm{P}_{\mathrm{org}}\right)$, as a result of the combined action of plant- and microbial-exuded carboxylates for mobilization and enzymes for mineralization, constitute a valuable yet poorly understood resource (George et al. 2018; MenezesBlackburn et al. 2018). The options for their management and their effects on crop P nutrition status and yield are therefore of paramount interest to both agronomists and farmers.

Cover cropping is the practice of growing plants, usually in the off-season, leaving their biomass on the field to provide various benefits for the agroecosystem, including erosion reduction, soil organic matter (SOM) build-up, weed and pathogen control, and nutrient management. Cover crops are also used to improve the P efficiency of added organic or mineral fertilizers by increasing soil biological activity or uptake and protection of soluble mineral P in strongly P-fixing soils (Kamh et al. 1998; Kuo et al. 2005). In principle, most plant species could be used for these purposes, and the list of plant species that can be used as cover crops is rapidly expanding. However, agronomic requirements of the cover crops (e.g., rapid growth and high biomass production, weed suppression, easy termination) impose some restrictions. Plant species in general, and therefore also when used as cover crops, vary greatly in their biomass production, soil exploration, exudation of P-mobilizing and organic P-mineralizing compounds, as well as their interaction with the rhizosphere microbial community. The variety of strategies for P-acquisition employed by different plant types must be considered, as, e.g., non-mycorrhizal species, while highly efficient at $\mathrm{P}$ mobilization, do not necessarily interact strongly with soil microbes (Lambers and Teste 2013; Lambers et al. 2015a). The inclusion of cover crops with special properties such as, e.g., the increase of the inoculum potential by arbuscular mycorrhizal fungi, can be beneficial in agricultural rotations that use domesticated cash crops developed in high-input breeding systems (Plenchette et al. 2005). Conservation agriculture, defined by the combination of cover crops, conservation tillage, and an adequate crop rotation (Hobbs et al. 2008), decreases labor intensity and frequency, enhances soil rest, and benefits soil biota. Here, crop residues are mixed less deeply into the soil than under conventional tillage, modifying soil biological parameters and mineralization dynamics. Other effects of management could result from the termination method used (e.g., spraying or roll-chopping) for winter-hard cover crops (Creamer and Dabney 2002).

The effects of cover crops and conservation tillage on crop yield and soil properties, especially nitrogen $(\mathrm{N})$ dynamics, have been the subject of many studies, several reviews (Dabney et al. 2001; Dreymann et al. 2005; Tonitto et al. 2006; Dahlin and Stenberg 2009), and projects (Crossland et al. 2015). However, P dynamics have, until recently, rarely been addressed. Some 
reviews on the underlying mechanisms of plant and microbial $\mathrm{P}$ acquisition and resulting implications for agricultural management have provided a theoretical foundation for predicting the influence of cover crops on P dynamics (Horst et al. 2001; Guppy et al. 2005; Richardson and Simpson 2011; Richardson et al. 2011; Damon et al. 2014). Interestingly, those publications have largely reflected their regional conditions; climate, soil P content and sorption capacity. Studies of Pfertilization efficiency, often associated with pastures, come mainly from Australia (Rose et al. 2010a; Simpson et al. 2011; McLaughlin et al. 2011; Faucon et al. 2015). Brazilian studies have emphasized conservation agriculture and acid soils with poor $\mathrm{P}$ availability (LeMare et al. 1987; Calegari et al. 2013; Balota et al. 2014; Fageria et al. 2016; Varela et al. 2017), while Scandinavian researchers have concentrated on $\mathrm{P}$ leaching (Liu et al. 2015; Aronsson et al. 2016). In the USA, cover crops of different species have been investigated (Lal et al. 1978), including their effects on mycorrhizal fungi (Galvez et al. 1995; Zibilske and Makus 2009; Rick et al. 2011; Maltais-Landry 2015), whereas in China and India, studies have often focused on microbial inoculants (Devi et al. 2013; Cui et al. 2015). In some African countries, India, and Mexico, with their prevalent traditional smallholder cropping systems, agroforestry and intercropping have been important topics for research (LeMare et al. 1987; Tarawali et al. 1999; Dinesh et al. 2004; Sileshi et al. 2008; Castillo-Caamal and Caamal-Maldonado 2011; Devi et al. 2013; Tanwar et al. 2014; Parihar et al. 2016). Previous meta-analyses have been concerned mainly with the effects of cover crops on Zea mays (maize) yield in North America (Miguez and Bollero 2005), effects on soil properties and yield in the South American Pampas region (Alvarez et al. 2017), response to woody and herbaceous legumes in sub-Saharan Africa (Sileshi et al. 2008), soil organic carbon (Poeplau and Don 2015) as well as Nitrogen dynamics (Tonitto et al. 2006). P nutrition and dynamics have not been a focus of the meta-analyses in these agro-ecosystems. Consequently, understanding whether and how cover crops can benefit the P nutrition of following main crops is sorely needed.

The aim of our review is to bridge our present knowledge of soil-plant-microbe interactions with the potential of cover crops to stimulate $\mathrm{P}$ dynamics in agricultural ecosystems. We begin with a description of $\mathrm{P}$ pools and P-acquisition mechanisms of cover crops, and present a conceptual framework of how $\mathrm{P}$ dynamics of cover crops and main crops may be linked. Both plants and soil microorganisms are involved in $\mathrm{P}$ dynamics of agroecosystems; we therefore present the most important mechanisms and pathways for both with respect to cover crops. We reviewed the conceptual framework through an extended meta-analysis that included 240 datasets derived from 25 studies. The focus of the metaanalysis was to elucidate whether

(1) P acquisition by cover crops stimulates growth and $P$ uptake of different main crops;

(2) cover crops enhance mycorrhizal colonization, short-term storage of $\mathrm{P}$ in soil microorganisms, and $\mathrm{P}$ mineralization, improving plant- and microbial-driven $\mathrm{P}$ uptake of the main crop;

(3) site conditions (e.g., fractions of available P) modify $\mathrm{P}$ benefit to the main crop; and

(4) cover crop management (i.e. species mixtures, tillage intensity, and fertilization) can be used to increase $\mathrm{P}$ benefits of the main crop.

Availability of phosphorus

Plant $\mathrm{P}$ nutrition is constrained by limited availability, due to physicochemical processes in the soil, of orthophosphate, the form that is taken up by roots. Phosphorus compounds interact strongly with the soil through sorption to particle surfaces (including SOM), slow diffusion into aggregates, and formation of precipitates with cations of calcium $(\mathrm{Ca})$, as well as sorption onto oxides and hydroxides of iron (Fe) and aluminium (Al) (Kelly and Midgley 1943), under alkaline and acid conditions, respectively. These interactions result in low $\mathrm{P}$ availability and P-fertilizer efficiency (McLaughlin et al. 2011). Soils with low P-sorption capacity also exhibit the associated hazard of $\mathrm{P}$ losses via leaching, whereas P-sorbing soils have problems with P-fertilizer efficiency due to immobilization of added P. As P-fertilizer efficiency is only 10$20 \%$ in the short term (Chien et al. 2011), agricultural soils in industrialized countries have commonly received excessive loads of $\mathrm{P}$ over decades, often without reaching the soil saturation limit. This accumulated $\mathrm{P}$ constitutes a valuable resource that could be accessed by employing appropriate cropping systems. For a recent review about pools of recalcitrant $\mathrm{P}$ in agricultural soils and opportunities for mobilization, see Menezes-Blackburn et al. (2018). On the other hand, highly-weathered soils in the tropics are $\mathrm{P}$ impoverished, and rich in $\mathrm{Fe} / \mathrm{Al}$ oxides and 
hydroxides (Simpson et al. 2011). In these systems, efficient recycling and use of the available inputs is essential. Phosphorus inputs into soil are from weathering of P-containing minerals or mobilization/ mineralization of other $\mathrm{P}$ pools of low availability, as well as atmospheric deposition by dust, and by fertilizer application. Phosphorus is removed from the system through biomass of harvested crops, by erosion, and by leaching, and is accompanied by accumulation of $\mathrm{P}$ forms of low availability (Condron et al. 2005). Erosion, globally the biggest threat to sustainable soil stewardship (Bernoux et al. 2006; Durán Zuazo and Rodríguez Pleguezuelo 2008), is one of the major losses of agricultural $\mathrm{P}$, as it is often associated with particle fractions prone to transport.

Soil P consists of both large, but stable and small, but highly-dynamic pools (Sharpley 1995). Although in heavily fertilized agricultural soils labile $\mathrm{P}_{\mathrm{i}}$ may temporarily dominate the plant-available pools (Negassa and Leinweber 2009), usually $30-65 \%$ of total $\mathrm{P}\left(\mathrm{P}_{\mathrm{t}}\right)$ is present in organic forms (Harrison 1987; Condron et al. 1990), and more in soils with high SOM content (Borie and Zunino 1983). During pedogenesis, the primary P-bearing minerals are slowly depleted, with highly weathered soils containing almost exclusively occluded $\mathrm{P}$ and $\mathrm{P}_{\text {org }}$, which is tightly recycled in the biomass (Smeck 1985). Organic P can contribute to crop nutrition, as plants and microbes can access the more labile $\mathrm{P}_{\text {org }}$ by a combination of mobilization with carboxylates and subsequent enzymatic mineralization (Condron et al. 2005; Richardson and Simpson 2011). In addition to phospholipids and nucleic acid-P (both forms account for less than $10 \%$ of total soil $\mathrm{P}_{\text {org }}$, but comprise most of the microbial $\mathrm{P}\left(\mathrm{P}_{\mathrm{mic}}\right)$ ), inositol phosphates (phytate) accumulate in soil due to their stable nature, and represent the major fraction of $\mathrm{P}_{\text {org }}$ (Jones and Oburger 2011). The inositol molecules consist of 16 phosphates attached to a $\mathrm{C}_{6}$-ring with ester-bonds, requiring specialized enzymes for breakdown; they also interact strongly with the soil due to their high charge density (Turner et al. 2002; Turner 2007). Due to low substrate availability, low phytase production by roots, and low enzyme-substrate efficiency in soils, only some plant species can access phytate to a limited extent (Menezes-Blackburn et al. 2012). However, several plant species are able to grow with sodium $(\mathrm{Na})$ hexaphytate as their sole $\mathrm{P}$ source in the laboratory (Steffens et al. 2010). In natural soils with endogenous phytates, mobilization via carboxylates and subsequent interactions with microbes appear necessary for plants to use this resource. For a full review of inositol phosphates, see Turner et al. (2007).

The direction of the effect of long-term SOM accumulation by cover crops on $\mathrm{P}$ availability is not clear. Improved soil physical-chemical parameters (e.g., water-holding capacity, aggregate stability) (Dorado et al. 2003) may increase $P$ availability to crops directly or indirectly (Eichler-Löbermann et al. 2008). Some fractions of SOM may compete with P for binding sites on particle surfaces, decreasing P-sorption capacity (Janegitz et al. 2013). However, large amounts of $P_{\text {org }}$ are in the form of uncharacterized high-molecularweight organic material (McLaren et al. 2015), linking the accumulation of poorly-available $\mathrm{P}_{\text {org }}$ closely to SOM dynamics. This could constitute a problem for the exploitation of these pools (Romanyà et al. 2017), as SOM is needed for soil structure, fertility, and climate change mitigation, and one target of cover cropping is to increase SOM content in soils. However, the fact that $\mathrm{C}: \mathrm{N}$ :Sulfur (S) ratios are relatively constant across soils, whereas $\mathrm{C}: \mathrm{P}$ and $\mathrm{C}: \mathrm{P}_{\text {org }}$ are more variable, may allow increasing available $\mathrm{P}\left(\mathrm{P}_{\mathrm{a}}\right)$ through $\mathrm{P}_{\text {org }}$ mineralization without affecting SOM accumulation. A P-priming effect has been described (Randhawa et al. 2005), but remains unresolved due to methodological constraints (Damon et al. 2014).

The most common way to characterize soil $\mathrm{P}$ is by using variants of the Hedley fractionation, which determines the amount of $\mathrm{P}_{\mathrm{i}}$ and $\mathrm{P}_{\text {org }}$ in various soil extracts (i.e. $\mathrm{NaHCO}_{3}, \mathrm{NaOH}, \mathrm{HCl}$ ), which are used to represent pools of differing degrees of availability (Hedley et al. 1982; Cross and Schlesinger 1995). However, the net contribution of these operational fractions to uptake by microbes and plants, and therefore the validity of the method for the prediction of plant $\mathrm{P}$ uptake, is not straightforward (Negassa and Leinweber 2009; Rose et al. 2010b). Olsen-P (Olsen et al. 1954), using $\mathrm{NaHCO}_{3}$ as extractant, is one of the most widely used methods and often correlates well with yield and $\mathrm{P}$ uptake, but was originally developed for calcareous soils. There are many other extractants for soil P testing methods, including Mehlich-III (Mehlich 1984), Bray 1 (Bray and Kurtz 1945), water (van der Paauw 1971), calcium-ammonium-lactate (CAL) (Schüller 1969) and Colwell (1963). Their application differs, even among regions in the same country, due to prevailing soil characteristics, but also due to historical reasons. More recently developed test methods that show promising 
results such as resin-P and "diffusive gradients in thinfilms" (DGT) (Mason et al. 2013) are not yet widely used. One issue is that the color methods used in routine soil testing, mostly molybdate-blue (Murphy and Riley 1962), do not account for $P_{\text {org }}$ (Steffens et al. 2010). This has been justified based on the assumption that $\mathrm{P}_{\text {org }}$ seems to play a minor role in plant nutrition under high availability of $\mathrm{P}_{\mathrm{i}}$ (Guo et al. 2000), but has consequences for systems dependent on $P_{\text {org }}$ (Dao et al. 2015). The combination of imperfect P-test methods and substantial knowledge gaps in understanding the complex $\mathrm{P}$ dynamics in soils constricts a scientific elaboration of general agricultural recommendations (Turner et al. 2005). Another problem is the definition of "plant-available P", as there are major differences among plant species (Lambers et al. 2006) and even crop varieties (Pang et al. 2018a) regarding their ability to access different soil $\mathrm{P}$ pools.

\section{Phosphorus acquisition by cover crops}

Plant species differ greatly in their P-acquisition strategies. The ability of cover crops to access poorlyavailable soil $\mathrm{P}$ is often superior to that of cash crops (Fig. 1). Their strategies can be summarized as: 1) exploration of a greater soil volume by an adaptive root architecture and root morphology; 2) mobilization of sparingly-soluble inorganic and organic P forms; and 3) mineralization of $P_{\text {org }}$. These mechanisms may all be enhanced through interaction with soil microbes.

In addition to the transfer of $\mathrm{P}_{\mathrm{a}}$ via cover crop residues to the main crop and to chemical rhizosphere modifications, some studies attribute benefits of cover crops to the subsequent crop to the soil microbial community, which influences $\mathrm{P}$ dynamics, both during the cover crop and the main crop phases (Nuruzzaman et al. 2005a; Pypers et al. 2007; Rose et al. 2010a; Mat Hassan et al. 2013).

Plants interact with the soil microbial community by releasing organic compounds into the rhizosphere that serve as substrates and signaling molecules to the microbes, increasing their abundance and activity severalfold (Bünemann et al. 2004; Balota et al. 2014). Our current knowledge indicates that both plants and soil determine microbial community composition (Marschner et al. 2001; Nannipieri et al. 2008). Together with plant roots, microbes are the principal drivers of $\mathrm{P}_{\mathrm{i}}$ and $\mathrm{P}_{\text {org }}$ solubilization and of the mineralization of more or less recalcitrant $\mathrm{P}_{\text {org }}$ in soil. They possess a diverse array of mechanisms to increase $\mathrm{P}$ acquisition by plants, including modifications and extension of root systems, allowing roots to access P-rich substrates that are otherwise unavailable to plants due to their location in the soil (i.e. in narrow pore spaces).

\section{Root architecture}

The differences in $\mathrm{P}$ uptake by cover crops are determined partly by their root architecture, with topsoil exploration and root hair density the most important traits for improved $\mathrm{P}$ uptake (Richardson et al. 2011). The kinetic properties of the $\mathrm{P}_{\mathrm{i}}$ uptake system, unlike those of more mobile nutrients such as nitrate, are not a major rate-limiting step in plant $\mathrm{P}$ acquisition (Clarkson 1985; Barber 1995). Mycorrhizal fungi play a fundamental role as extensions of the roots, whereas other microorganisms promote root growth and modify root architecture (branching, root hairs) via signaling molecules in the rhizosphere (Hayat et al. 2010). Cover crops with more extensive root systems scavenge $\mathrm{P}$ from a larger and deeper soil volume, and make it potentially available for main crops with shallow roots (Dube et al. 2014). Some plants (e.g., Lupinus species), possess specialized root structures, termed cluster roots, that exploit soils with low $\mathrm{P}$ availability and potentially enhance $\mathrm{P}$ availability for the main crop (Nuruzzaman et al. 2005b; Lambers et al. 2006). They may additionally facilitate $\mathrm{P}$ acquisition for neighboring plants (Gardner and Boundy 1983; Horst and Waschkies 1987; $\mathrm{Cu}$ et al. 2005).

To date, the most extensive description of cover crop traits related to $\mathrm{P}$ uptake is that by Wendling et al. (2016), who classified cover crops into five groups based on shoot biomass and nutrient concentration, comprising species from different families. The main findings of this study were shoot and root traits, rather than taxonomy; species with high nutrient concentrations and high root length density were recommended under high-fertility conditions and from a short-term perspective. However, although biochemical and microbial root $\mathrm{P}$-acquisition strategies were not assessed in this study, they may well have been relevant, especially in systems with low P availability.

\section{Phosphorus mobilization}

Soil P-mining strategies enhance desorption and solubilization of sparingly-available $\mathrm{P}_{\mathrm{i}}$ and $\mathrm{P}_{\text {org }}$ pools, which 


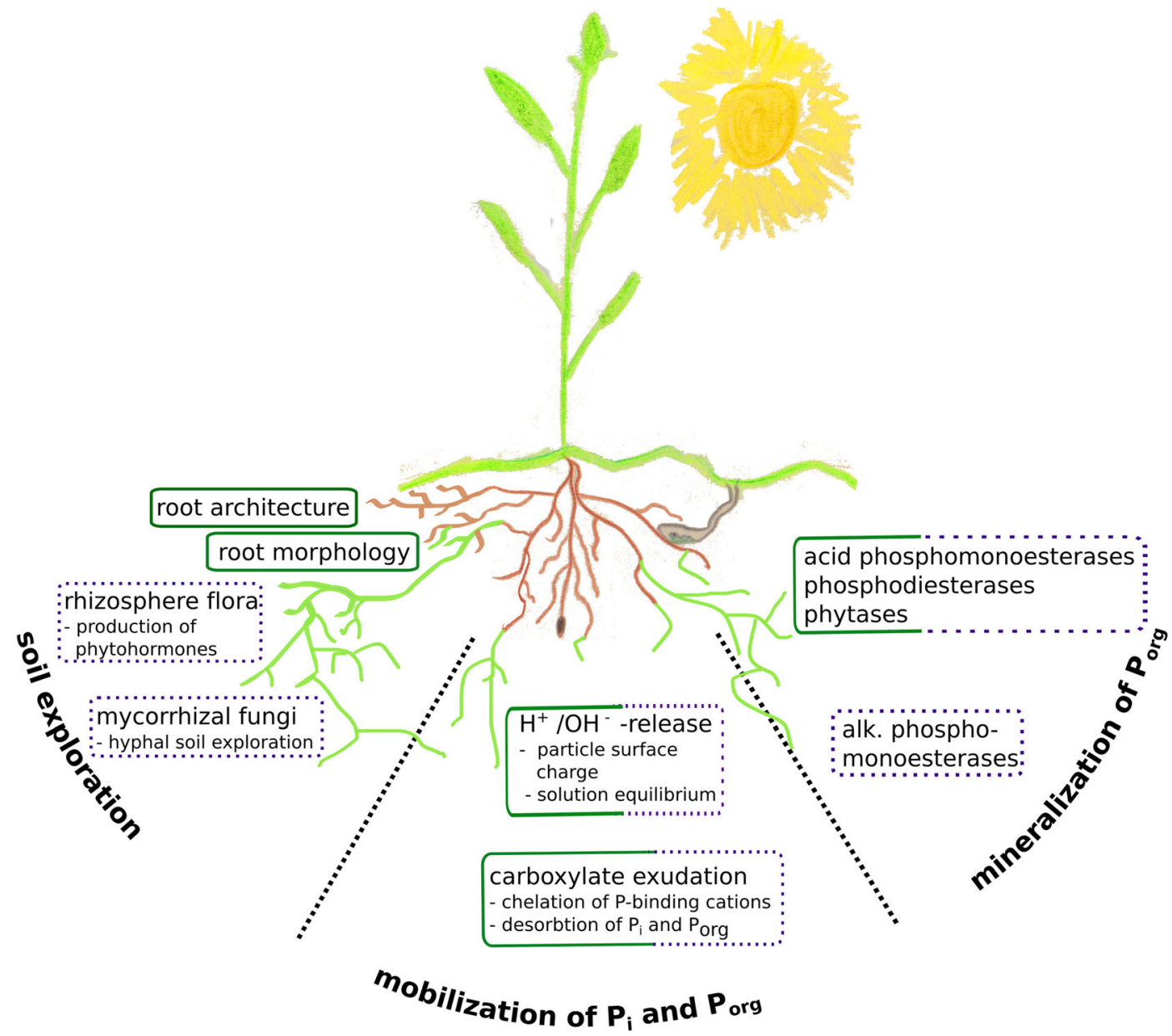

Fig. 1 Strategies and mechanisms for phosphorus (P) acquisition by plants: 1) soil exploration via roots and mycorrhizal hyphae; 2) mobilization of sparingly-soluble inorganic $\mathrm{P}\left(\mathrm{P}_{\mathrm{i}}\right)$ and organic $\mathrm{P}$

often limit $\mathrm{P}$ availability. Plants and microbes are capable of exuding low-molecular-weight organic anions (carboxylates) to dissolve precipitates and chelate metal cations, both of which make phosphate unavailable; because carboxylates facilitate the release of sorbed $\mathrm{P}$ via ligand-exchange reactions (Hinsinger 2001), and block binding sites on soil particles, they increase the concentration of $\mathrm{P}$ in solution (Ohno and Crannell 1996). The $\mathrm{pH}$ of the soil solution is modified by exudation of $\mathrm{H}^{+}$or $\mathrm{OH}^{-} / \mathrm{HCO}_{3}{ }^{-}$. This, in turn, determines the variable surface charge of minerals and SOM, and may also increase $\mathrm{P}$ in solution. Proton release enhances $P$ availability only in calcareous soils, due to the dissolution of Ca-phosphate. However, as the (bio)chemistry of $\mathrm{P}$ in soils is very complex, with many processes occurring simultaneously, sometimes in opposite
( $\mathrm{P}_{\text {org }}$ ) by exudation of $\mathrm{H}^{+} / \mathrm{OH}^{-}$and carboxylates; 3 ) mineralization of $\mathrm{P}_{\text {org }}$ by phosphatases. Plant-driven processes have solid outlines, microbial activity is shown by dotted outlines

directions, it is difficult to predict the effect of $\mathrm{pH}$ changes on $\mathrm{P}$ dynamics. A review of $\mathrm{P}_{\mathrm{i}}$ bioavailability in the rhizosphere was written by Hinsinger (2001). Despite their name, 'organic acids' do not substantially decrease rhizosphere $\mathrm{pH}$, as they are mostly released as organic anions, generally with cations other than protons as balancing ions (Zhu et al. 2005; Roelofs et al. 2008). Exudation of P-solubilizing organic anions differs strongly among plant genotypes and soils (Kamh et al. 1998; Nuruzzaman et al. 2006) and is related to $P$ deficiency and Al toxicity (Richardson et al. 2011). Citrate is a commonly released organic anion and one of the most effective for P mobilization (Jones 1998). It is produced in large quantities by Lupinus albus (Gardner et al. 1983; Dinkelaker et al. 1989; Cu et al. 2005) and other legumes (Kamh et al. 2002), including 
Cicer arietinum (chickpea) (Veneklaas et al. 2003), Vicia faba (faba bean) (Li et al. 2007), and Trifolium pratense (red clover) (Gerke and Meyer 1995), but also by Brassica napus (canola) (Hoffland et al. 1992). The strategy of dicots (e.g., Fabaceae, Brassicaceae) is to utilize biochemical rhizosphere modification for P mobilization, whereas Poaceae predominantly take up $\mathrm{P}$ using their extensive root systems (Maltais-Landry 2015; Schnug and De Kok 2016). The exudation of different organic anions and acidification may be complementary (Gerke and Meyer 1995), but the mechanisms are complex and the result depends strongly on soil chemistry and P level (Oburger et al. 2011). Complicating the system further, microorganisms function as both potential sinks and alternative sources of carboxylates (Deubel et al. 2000), and soil fauna remobilize P from the microbial biomass (Hinsinger et al. 2015). The identification of $\mathrm{pH}$ as the principal driver of microbial diversity in soils (Philippot et al. 2009) paired with substantial changes in $\mathrm{pH}$ in the rhizosphere led Hinsinger et al. (2009) to the hypothesis that rootinduced $\mathrm{pH}$ changes shape the structure of the rhizosphere microbial community equally or more importantly than root $\mathrm{C}$ deposition.

Microbes may use plant exudates to produce Psolubilizing compounds in the rhizosphere, complementing $\mathrm{P}$ mobilization by roots (Schilling et al. 1998). In fact, some root exudates do not function directly in plant nutrient acquisition, but are composed of mobile sugars, which can be used by the rhizosphere microbial community. The critical role of desorption for the mineralization of $\mathrm{P}_{\text {org }}$ is receiving increasing attention (Giaveno et al. 2010). Pseudomonas species are among the most frequently studied P-solubilizing bacteria, but also species of Burkholderia, Enterobacter, Pantoea, Bacillus solubilize P (Jorquera et al. 2008). Together with arbuscular mycorrhizal fungi (AMF), Psolubilizing microorganisms are a target for the development of microbial inoculants, although often with limited success in the field (Parray et al. 2016).

The potential of some plants to mine sparinglyavailable $\mathrm{P}$ pools led to optimism about their potential to increase $\mathrm{P}$ availability when used as cover crops (Teboh and Franzen 2011; Boglaienko et al. 2014). However, under conditions of P-deficiency, plants do not always respond by releasing organic anions and their effect on P uptake is not consistent (Wang et al. 2016).

The minor direct benefits of cover crop rhizosphere modification (i.e. carboxylate exudation) for subsequent crops (Possinger et al. 2013) may be explained by the short duration of carboxylate exudation (a few weeks) associated with legume roots, limiting their effects on the main crop (Nuruzzaman et al. 2005a). Notwithstanding, the binding of carboxylates to $\mathrm{Fe} / \mathrm{Al}$ hydroxides could delay microbial mineralization (Jones and Edwards 1998) and reduce soil P-sorption capacity. The ability of microorganisms to access sparinglyavailable $\mathrm{P}$ with benefits to plants may depend on microbial turnover (Richardson and Simpson 2011), as the microbial biomass conserves solubilized P.

The inclusion of carboxylates and other rhizosphere processes could improve plant nutrition models, which have to date failed to predict the actual uptake of $\mathrm{P}$ and other low-mobility nutrients, especially under low-input conditions (Hinsinger et al. 2011). Leaf manganese (Mn) concentration, for example, can be used as a proxy for carboxylate concentration in the rhizosphere, providing a tool that may be more reliable than measurement of rhizosphere carboxylates, given their transient nature in the field (Lambers et al. 2015b; Pang et al. 2018a).

\section{Mineralization}

In addition to mobilization mechanisms described above, the considerable amounts of $\mathrm{P}_{\text {org }}$ in soil require, once in solution, enzymatic hydrolysis to become plantavailable $\mathrm{P}_{\mathrm{i}}$. In pot experiments, the activity of phosphatase enzymes was three-fold and nine-fold greater in the rhizosphere of Triticum aestivum (wheat) and Lupinus albus (white lupin), respectively, than in bulk soil, and thisincreasedactivity was, in both cases, associated with the depletion of soil $P_{\text {org }}$ (Nuruzzamanetal.2006). However, phosphatases also have a role in recycling $P$ inside cells and recapturing $\mathrm{P}_{\text {org }}$ lost from roots or microbial cells (Tarafdar and Jungk 1987; Barrett-Lennard et al. 1993). Experiments with transgenic Trifolium repens have shown that, under laboratory conditions, transgenic expression of phytase and purple acid phosphatase genes from Medicago truncatula increased the plants' ability toutilizeorganicPinresponsetoPdeficiency (Ma etal.2009). The use of these techniques is convenient for experimentation, but in the field, the efficacy of single exudation traits appears to be limited in P-deficient soil conditions where the soil does not exactly match the functional requirements of the enzymes of interest (Giles etal.2017). 
Extracellular enzymes interact strongly with soil particles, leading to adsorption and inactivation, but also to protection against degradation (Rao et al. 2000). Adsorption depends on the mineral composition of the soil (Ditterich et al. 2016) and characteristics of the SOM. There are indications that carboxylates may serve a dual role of desorbing $\mathrm{P}$ and providing a favorable $\mathrm{pH}$ for the phosphatase enzymes, increasing enzymatic activity (Furutani et al. 2017)

Due to sorption processes, the effect of plant-derived phosphatases will be restricted to a few millimeters of distance from the roots. However, mobile rhizodeposited sugars penetrate further into the bulk soil, and can be used by microbes to produce phosphatases, extending the range of $\mathrm{P}_{\text {org }}$ mineralization around the roots. Due to complex interactions with soil, microbial degradation, and interception of the products, increased phosphatase activities do not necessarily translate into a more rapid P-uptake rate for plants.

Under natural conditions, the microbial contribution to the mineralization of $\mathrm{P}_{\text {org }}$ in the rhizosphere is undisputed; however, it is often difficult to separate the origin of enzymatic activity, as some enzymes, such as acid phosphatases and some phytases, are produced both by plants and microbes (Nannipieri et al. 2011). Diesterases can be produced by plants also, but diesterase activity is mainly related to microbial biomass (Turner and Haygarth 2005; Lang et al. 2017). Alkaline phosphatases, however, some phytases (Azeem et al. 2015) and phosphonate hydrolases (Hunter et al. 2014) are produced only by microbes. Zymography is a promising in situ method for analysis of the two-dimensional distribution of enzymatic activity in soil. In an experiment with Lupinus albus it was combined with ${ }^{14} \mathrm{C}$ imaging, revealing that alkaline phosphatase-producing microorganisms were not dependent on recent rhizodeposition, whereas acid phosphatase activity was concentrated in the direct vicinity of the roots (Spohn and Kuzyakov 2013a). The relative contributions of microbial groups to the activities of the different phosphatases requires further investigation (Turner and Haygarth 2005). In contrast with plants, which take up $\mathrm{P}$ exclusively as $\mathrm{P}_{\mathrm{i}}$, microorganisms may be able to take up low-molecularweight $\mathrm{P}_{\text {org }}$, and protozoa can make use of highmolecular-weight $P_{\text {org }}$ (Jones and Oburger 2011).

The capacities of a plant species to solubilize and mineralize $\mathrm{P}_{\text {org }}$ forms may be related to its rhizosphereassociated microbes. For example, the pasture plants Lolium perenne (perennial ryegrass) and Trifolium repens (white clover) have predominantly phytatemineralizing bacteria in their rhizospheres, whereas in the cereal crops Avena sativa (oat) and Triticum aestivum (wheat), P-solubilizing bacteria dominate in the rhizosphere. Conversely, Lupinus luteus (yellow lupin) shows the lowest proportion of both bacterial types in a Chilean volcanic soil (Jorquera et al. 2008). Larger quantities of phytate-mineralizing and Psolubilizing fungi can be isolated from the rhizosphere of leguminous crops as compared with those of cereals (Gaind and Nain 2015). The ecological interactions between $r$-strategists in the rhizosphere and $K$-strategists in the bulk soil may also influence $\mathrm{P}$ mineralization (Hunter et al. 2014).

Strategies used by plants vary. There is a rather microbe-independent strategy, as in Lupinus albus, which releases inhibitors that prevent microbial degradation of root-derived carboxylates and phosphatases, intensively changing the chemistry of a small volume of soil around the cluster roots (Weisskopf et al. 2006). However, there are also non-mycorrhizal Brassicaceae with high levels of rhizodeposition, and mycorrhizal plants that scavenge $\mathrm{P}$ from a greater soil volume at a lower intensity. Therefore, the P-acquisition strategy of the cover crop influences the mechanisms of P-benefit to the main crop. A selection of common cover crop species and their properties is described in Table 1.

Conceptual framework: how do cover crops affect $\mathrm{P}$ dynamics?

Among the $\mathrm{P}$ dynamics affected by the soil-plantmicrobe processes of cover cropping (Fig. 2), the most studied mechanism is the direct uptake of $\mathrm{P}_{\mathrm{a}}$ by plants and the transfer of $\mathrm{P}$ within the cover crop biomass. The storage of substantial quantities of $\mathrm{P}$, both by high biomass and high $\mathrm{P}$ concentrations, is methodologically relatively simple to assess. Phosphorus in the plant biomass is protected from sorption onto the soil (Groffman et al. 1987) or losses by erosion and leaching, but $\mathrm{P}$ mineralization needs to be in synchrony with the needs of the main crop. Some cover crops act through positive effects on the soil microbial community (i.e. earlier mycorrhizal colonization, production of enzymes and increased microbial $\mathrm{P}$ as a pool for plants), increasing the capacity of the crop-rhizobiome-system to access P (Oberson et al. 2006, Njeru et al. 2014). There is also chemical modification of the rhizosphere, via changes in $\mathrm{pH}$, carboxylate exudation, or phosphatase 


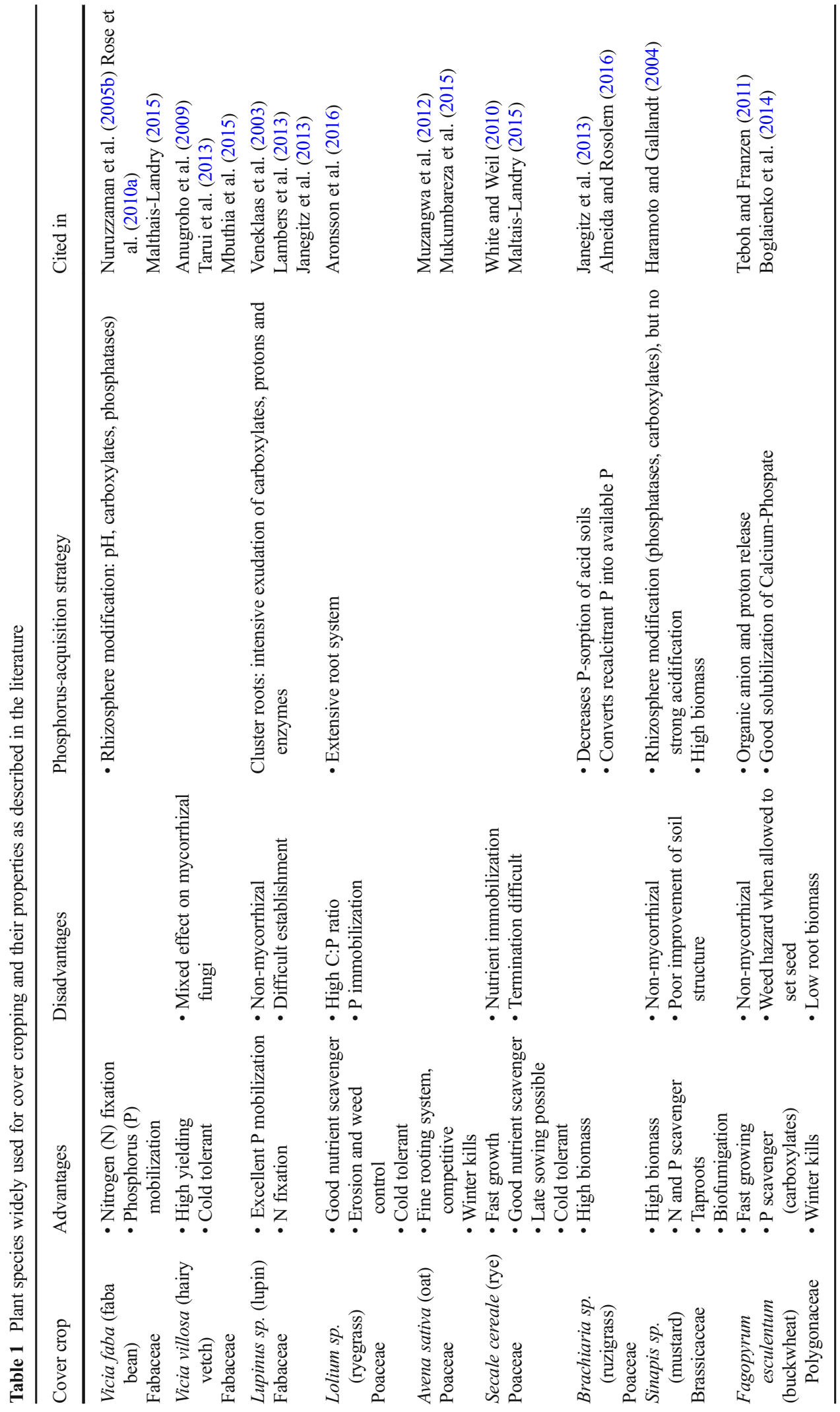




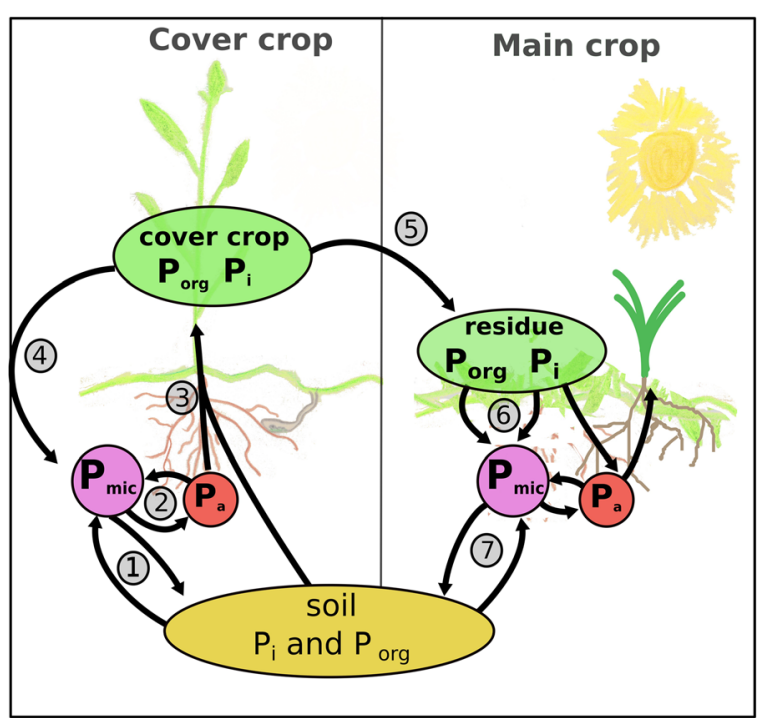

Fig. 2 Pathways of phosphorus (P) transfer and plant-microbial processes affecting $\mathrm{P}$ availability by cover cropping. 1) Soil $\mathrm{P}$ pools of varying degrees of availability are solubilized and/or mineralized and are immobilized in the microbial biomass. 2) The microbial biomass releases $\mathrm{P}$ into the soil solution which 3) ends up in the plant via root or mycorrhizal uptake. Cover crops may additionally possess the capacity to mine $\mathrm{P}$ from poorlyavailable $\mathrm{P}$ pools or to produce biochemical rhizosphere modifications to increase $P$ availability. 4) The roots release rhizodeposits that shape the microbial community, eventually leading to increased $\mathrm{P}$ mining. 5) The $\mathrm{P}$ stored in the cover crop biomass is transferred to the main crop via cover crop residues, which are decomposed by the soil microbial community (6). The soil microbial community (i.e. mycorrhizal fungi) in the main crop phase, enhanced by the cover crops, may possess an increased capacity to mine $\mathrm{P}$ for the main crop (7).

release, as described above. Biochemical P mobilization would be potentially greatest in soils with a high content of poorly-available $\mathrm{P}$, under the condition that chemical modification of the rhizosphere persists well into the main cropping phase. All these processes occur simultaneously with differing degrees of relative importance depending on the combination of agroecosystem and management.

\section{The meta-analysis}

In order to analyze the general effects of cover cropping on main crop performance in terms of $\mathrm{P}$ nutrition, we conducted a meta-analysis. We also assessed more specific effects, such as the multiple ways in which cover crops, interacting with microbes, influence $\mathrm{P}$ dynamics and $\mathrm{P}$ uptake of the main crop, as well as different cover crop-main crop combinations.
An initial search in 2017 for online available publications using Scopus with the key-words ("phosphorus" AND "cover crop" OR "green manure" OR "catch crop") yielded 638 matches that were screened by title and abstract. The literature cited in the studies meeting our criteria was also screened, and we expanded the search further using Google Scholar. We selected those studies that reported the effects on main crop yield and $\mathrm{P}$ uptake/P concentration, soil $\mathrm{P}$ and/ or soil biological parameters related to $\mathrm{P}$ cycling (phosphatase activity, microbial biomass $\mathrm{P}$, or abundance of AMF) and included a control treatment without cover crops. Phosphorus-mobilizing carboxylates are rarely measured in field studies and could not be included in the metaanalysis. We used only studies with cover crops and main crops grown in rotation, excluding intercropping or living mulch. Greenhouse experiments were excluded, as were agroforestry and grassland studies. Soil biological properties and available $\mathrm{P}$ were determined after termination of the cover crop or during growth of the main crop. Experimental factors such as main crop species and/or other factors (e.g., soils, tillage) and data from different years were treated as separate experiments within a study.

The soils included in this meta-analysis were classified according to their $\mathrm{P}$ availability, using the descriptions of the field experiments and the results of standard $P$ tests. Datasets from a single field experiment that had been published in several articles (e.g., yield and soil microbiology in different papers) were merged into a single dataset when possible. Details of the studies used (Weerakoon et al. 1992; Medhi and Datta 1996; Boswell et al. 1998; Vanlauwe et al. 2000; Kabir and Koide 2002; Somado et al. 2003; Jensen et al. 2005; Rutunga et al. 2008; Wang et al. 2008; Eichler-Löbermann et al. 2008; Oikeh et al. 2008; Takeda et al. 2009b; White and Weil 2010; Buyer et al. 2010; Rick et al. 2011; Tiecher et al. 2012a, 2012b; Karasawa and Takebe 2012; Njeru et al. 2014; Balota et al. 2014; Maltais-Landry et al. 2015; Karasawa and Takahashi 2015; Mbuthia et al. 2015; Ro et al. 2016; Pavinato et al. 2017) and the extracted data can be found in supplementary material $(\mathrm{S} 1+\mathrm{S} 2)$. The data were extracted from the publications using the shareware-tool DataThief III (Tummers 2006) and the open source software Tabula (Aristarán et al. 2017).

We used main crop yield and main crop $P$ uptake as response variables to evaluate the effect of cover crops, because yield is ultimately of interest to farmers. We decided against $\mathrm{P}$ concentration, because there is a trade-off between yield and nutrient concentration; that 
is, high-yielding cropping methods may decrease the concentration of some minerals in the crop (Garibay et al. 1997), whereas a crop with poor field emergence may have a high $\mathrm{P}$ concentration. Cover crop biomass and cover crop P uptake were also evaluated to characterize the different cover crop families. To assess the interactions between cover crops, soil microbial community, and the main crops, $A M F$ abundance/colonization, $P_{m i c}$, and phosphatase activity (alkaline and acid phosphomonoesterase, phosphodiesterase) were first treated as response variables to determine whether or not they were affected by cover cropping, then included in a separate analysis as moderating variables to determine their influence on main crop performance.

The categorical variables soil $P$ availability (high vs low) and climate (tropical vs temperate), and the agronomic factors tillage (inversion tillage vs non-inversion tillage/no-tillage), fertilization (P-fertilized vs unfertilized), and cropping system (conventional vs organic) were also used as moderating variables for the response variables.

The models had the following basic structure with their respective response and moderating variables:

$$
\begin{aligned}
& \log _{e}(\hat{y})=m(\text { fixed })+\operatorname{study}(\text { fixed })+ \\
& \text { study }: \text { experiment }(\text { nested }, \text { random })
\end{aligned}
$$

\section{$y$ response variable \\ $m$ moderating variables}

The response variables were all $\log _{\mathrm{e}}$-transformed to account for different units and scale effects, but backtransformed and reported as percentage change relative to the respective control treatments for graphical visualization. To calculate the relative percentage change by cover crops, the following formula was used:

$Y(\%)=\frac{\hat{y}_{\text {cover }_{\text {crops }}}-\hat{y}_{\text {control }_{j}}}{\hat{y}_{\text {control }_{j}}} * 100$

$$
\begin{array}{ll}
\hat{y}_{\text {cover crop }} & \begin{array}{l}
\text { modeled median or } 95 \% \mathrm{CI}, \text { respectively, } \\
\text { of the } j \text { th cover crop type } \\
\text { modeled median of the control treatments } \\
\text { corresponding to } j
\end{array} \\
\hat{y}_{\text {control }} &
\end{array}
$$

Bearing in mind possible interactions, cover crops and main crops were aggregated into phylogenetic families of similar properties (Table S2). Fabaceae and Poaceae cover crops were by far the most studied groups. Lupinus sp. were not included in the Fabaceae group due to the special P-mobilizing properties of this non-mycorrhizal genus (Lambers et al. 2013). Phacelia (Hydrophyllaceae, only tested in one study) was included in the Asteraceae family, due to similarities in their respective mycorrhizal competence and biomass production. Despite promising results, cover crop mixtures, usually consisting of a Poaceae and either a Brassicaceae or a Fabaceae, were seldom assessed.

Linear mixed models with study as fixed effect and the interaction of study and experiment as random effect were fitted using the package lme4 v1.1-15 (Bates et al. 2015) in $R$ v3.4.3 (R-Core Team 2013) and R-Studio v1.1.423 (RStudio 2013). Graphs were produced with the packages ggplot2 v2.2.1 (Wickham 2009) and cowplot v0.9.2 (Wilke 2017) with estimates from emmeans v1.1 (Lenth 2018) and percentages calculated with plyr v1.8.4 (Wickham 2011). As variance or related parameters were not reported in several studies, the observations were weighted by the number of replicates in each experiment with the weights-statement in the lmer function (all studies had a balanced design). Different models were compared using ML estimation, whereas the final models were fitted with REML. The structure of the fitted models and the F-tests obtained with the package lmerTest v2.0-36 (Kuznetsova et al. 2017) were provided in Table S3 using sjPlot (Lüdecke 2018), sample R code in Table S4.

There was a large variance in and among the published studies due to differences in climate, site conditions, experimental set-ups and management, but also substantial intra-study heterogeneity. Because of missing factor combinations (e.g., not all cover crops were grown with fertilization or tillage), we encountered some difficulties in accounting for interactions of factors. In some cases, we opted to use models with fewer interactions and a higher punctuation by Aikaike's Information Criterion (AIC) in order to be able to use a greater part of the dataset, under the condition that this did not substantially distort the model output. For the same reason, the moderating variables were tested in separate models. Main crop yield and P content do not represent exactly the same dataset, because not all studies reported both variables. In the studies with wetland rice, only Fabaceae were used as cover crops, so the 
yield and $\mathrm{P}$ uptake of this main crop were calculated separately.

\section{Results of the meta-analysis}

Cover crop biomass and P content

From the analysis of the aggregated data from the studies included in the meta-analysis it can be seen that the selection of cover crop was a relevant factor. Cover crop type determined the biomass produced and the tissue $\mathrm{P}$ concentration (Fig. 3, Table S3.1: Models 1.1-1.3). Biomass and $\mathrm{P}$ concentration were not correlated, resulting in differing C:P ratios: Poaceae cover crops produced the most biomass, but had the lowest $\mathrm{P}$ concentration; Polygonaceae had the lowest biomass and Fabaceae and Brassicaceae had rather high $\mathrm{P}$ concentrations.

\section{Crop rotation}

The integration of cover crops into crop rotations generally increased main crop yields (Fig. 4; Table S3.2: Models 2.1 and 2.2). Main crop yield benefit was determined by main crop species, cover crop type, and their interaction. Maize was most responsive to cover cropping. Other main crops (i.e. Glycine max (soybean) and cereals) tended to respond positively, but the increases were not significant. Wetland rice yields were significantly enhanced by Fabaceae cover crops (Table S3.2: Model 2.3). Brassicaceae, vegetables, and cotton (aggregated as other main crops) were tested in few studies with little response to cover cropping. The interaction cover crop type $\mathrm{x}$ main crop type improved the model significantly, although the F-test was not significant. Main crop P uptake was closely related to yields (Fig. S5).

The effect of cover cropping varied also at the species level, as shown for Fabaceae (Fig. 5; Table S3.3: Model 3 ), with the tropical legumes Lablab purpureus and Mucuna pruriens resulting in the greatest yield increases. Lupinus sp. performed intermediately among the Fabaceae, but the yield increases were not significant.

Soil biological variables

To understand the mechanisms by which cover crops might stimulate $\mathrm{P}$ cycling and yield of the main crop, we
Fig. 3 Cover crop dry matter biomass $\left[\mathrm{t} \mathrm{ha}^{-1}\right]$, shoot phosphorus (P) content $\left[\mathrm{kg} \mathrm{ha}^{-1}\right]$ and concentration of $\mathrm{P}$ in biomass $\left[\mathrm{g} \mathrm{kg}^{-1}\right]$. The points represent the modeled median $(+/-95 \% \mathrm{CI})$ of the different cover crop treatments. On the left are displayed the number of observations. The letters indicate significant differences among cover crop types with a Tukey post-hoc test $(p<0.05)$. The corresponding models can be found in Table S3.1

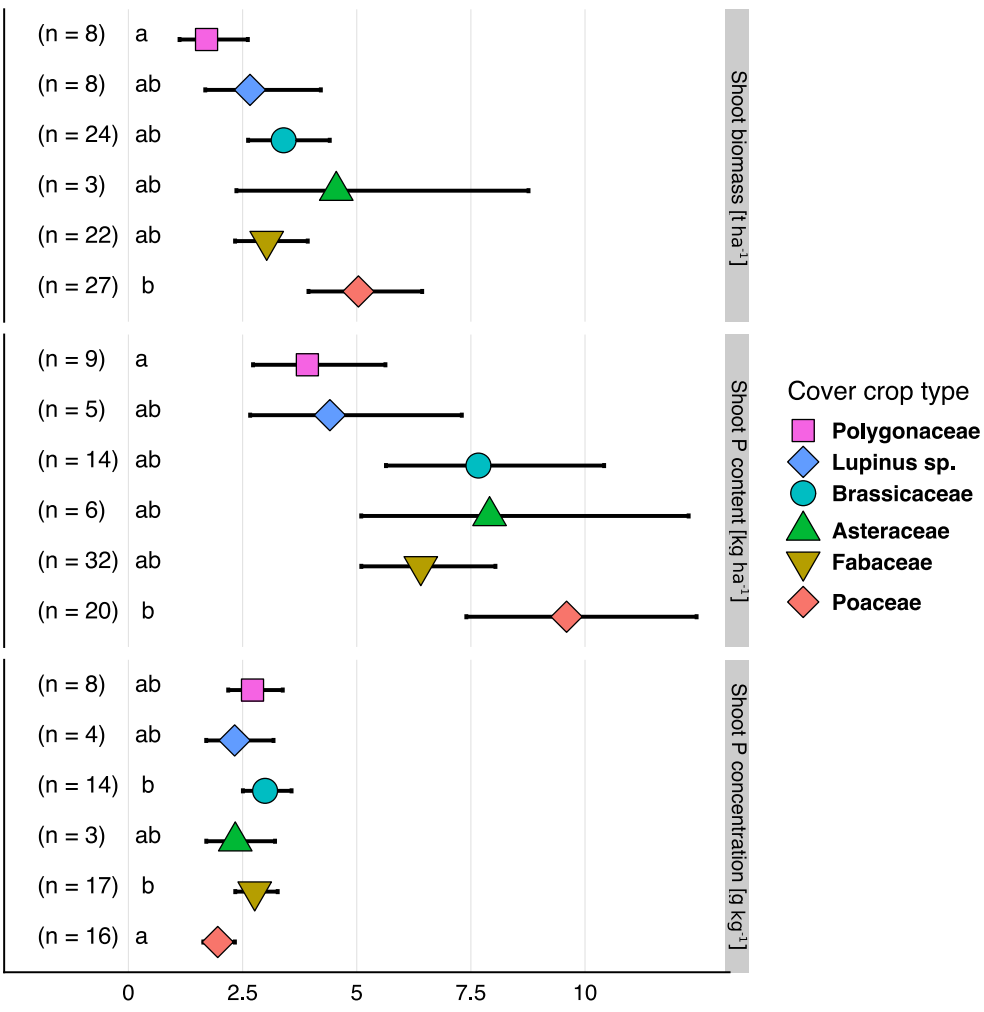




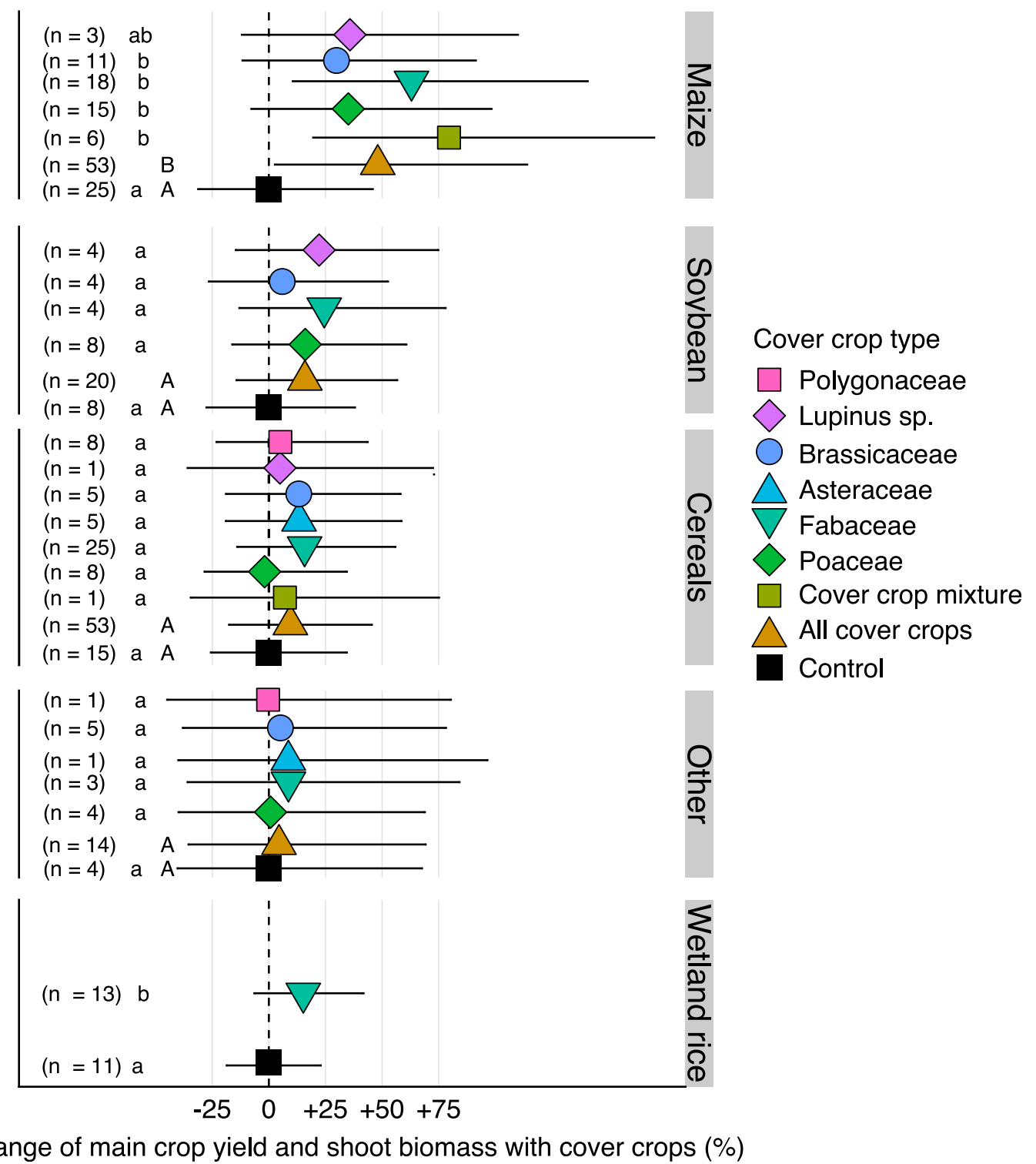

Fig. 4 Change in main crop yield and shoot biomass following cover crops from different families. The points represent the modeled median $(+/-95 \% \mathrm{CI})$, relative to the respective controls. On the left are displayed the number of observations. The lowercase letters indicate, for a single main crop type with a Tukey post-

explored the soil microbial community after application of different cover crop types. The effects on abundances of AMF, $\mathrm{P}_{\text {mic }}$, and on extracellular P-cycling enzymes (phosphatases) were tested (Fig. 6, Table S3.5: Models 5.1-5.8). Datasets for the soil biological variables included data from seven studies with 60 observations for mycorrhizal abundance, four studies with 53 observations for phosphatase activity, and two studies with 30 observations for $\mathrm{P}_{\text {mic }}$. Abundance of AMF spores and hoc test $(p<0.05)$, significant differences among cover crop types (including the control) and the upper-case letters between cover cropping in general and the controls. The corresponding models can be found in Table S3.2

root colonization increased after mycorrhizal cover crops (cover crop mixtures, Fabaceae and Poaceae), but did not change or increased only slightly after non-mycorrhizal cover crops (Brassicaceae and Lupinus sp.). Tillage did not significantly decrease mycorrhizal abundance in the present dataset. Cover cropping generally increased $\mathrm{P}_{\text {mic }}$ significantly; with Poaceae, Fabaceae, and Lupinus sp. resulting in the greatest increases, around $25 \%$, but only the effect 
Fig. 5 Change in main crop yield and shoot biomass after different Fabaceae cover crop genera and species. The points represent the percentage change of the modeled median $(+/-95 \% \mathrm{CI})$, relative to the respective controls. On the left are displayed the number of observations. The letters indicate significant differences among cover crop species with a Tukey post-hoc test $(p<0.05)$. Species with only one or two observations were aggregated as "other Fabaceae": Anthyllis vulneraria, Tephrosia purpurea, Stylosanthes guianensis, Pueraria phaseoloides, Psophocarpus tetragonolobus, Mucuna cochinchinensis, Dolichos lablab, Cassia tora, Canavalia ensiformis, Cajanus cajan, Trifolium sp., Arachis hypogaea. The corresponding model can be found in Table S3.3

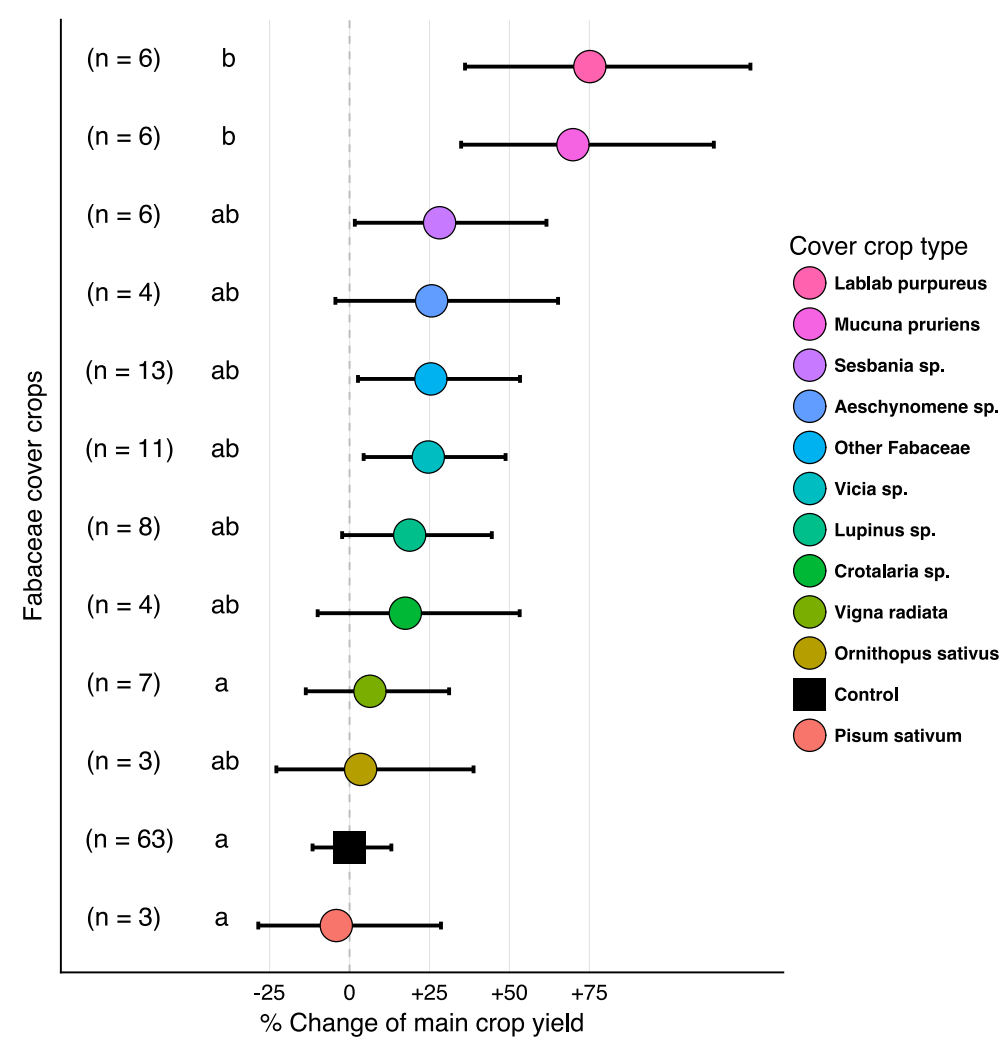

of Poaceae was significant. Microbial biomass $\mathrm{P}$ showed no relationship with main crop yield or $\mathrm{P}$ uptake (data not shown). Extracellular phosphatase activity increased around 20\% after cover cropping, with Brassicaceae treatments tending to result in the smallest increases over the control, and with Fabaceae, lupins, and Poaceae having the largest effect. Phosphatase activity did not affect main crop growth performance (data not shown).

Standard soil P testing (i.e. Olsen P or similar) was conducted in many studies after cover cropping in order to predict $\mathrm{P}$ availability to the main crop. Overall, cover crops had minor effects on the pools measured with these methods, with the exception of Lupinus sp., which increased $\mathrm{P}_{\mathrm{a}}$ markedly. There was no evident relationship between $\mathrm{P}_{\mathrm{a}}$ after cover cropping and main crop yield or P uptake.

Cover crop effects under different soil P conditions

We intended to explore the effect of cover cropping on soils differing in soil $\mathrm{P}$ status by classifying soil $\mathrm{P}_{\mathrm{a}}$ into low and high. The majority of studies were conducted in soils with a low $\mathrm{P}_{\mathrm{a}}$. Cover crops had more pronounced effects on main crop performance in these soils compared with systems with abundant labile P (Fig. 7; Table S3.6: Models 6.1 and 6.2). Additionally, under conditions of low $\mathrm{P}_{\mathrm{a}}$, the cover crop benefit was greatest. Cover crop effects on soil microbial parameters were also influenced by soil $\mathrm{P}$ status, reflected in a much stronger increase in AMF abundance in soils low in $\mathrm{P}_{\mathrm{a}}$ compared with high$\mathrm{P}_{\mathrm{a}}$ soils (Fig. 8; Table S3.7: Model 7).

\section{Discussion}

We performed a meta-analysis to explore the importance of different plant $\mathrm{P}$-acquisition strategies and to explain the benefit of cover crops on yield of main crops based on modified plant-microbe interactions during $\mathrm{P}$ cycling.

Main crops differ in their response to cover cropping

Our meta-analysis showed that cover crops have the potential to enhance both yield and $\mathrm{P}$ uptake of main crops in a variety of agroecosystems and under different management regimes, although the variance is very high. Main crops differ in their ability to profit from the P-benefit of 


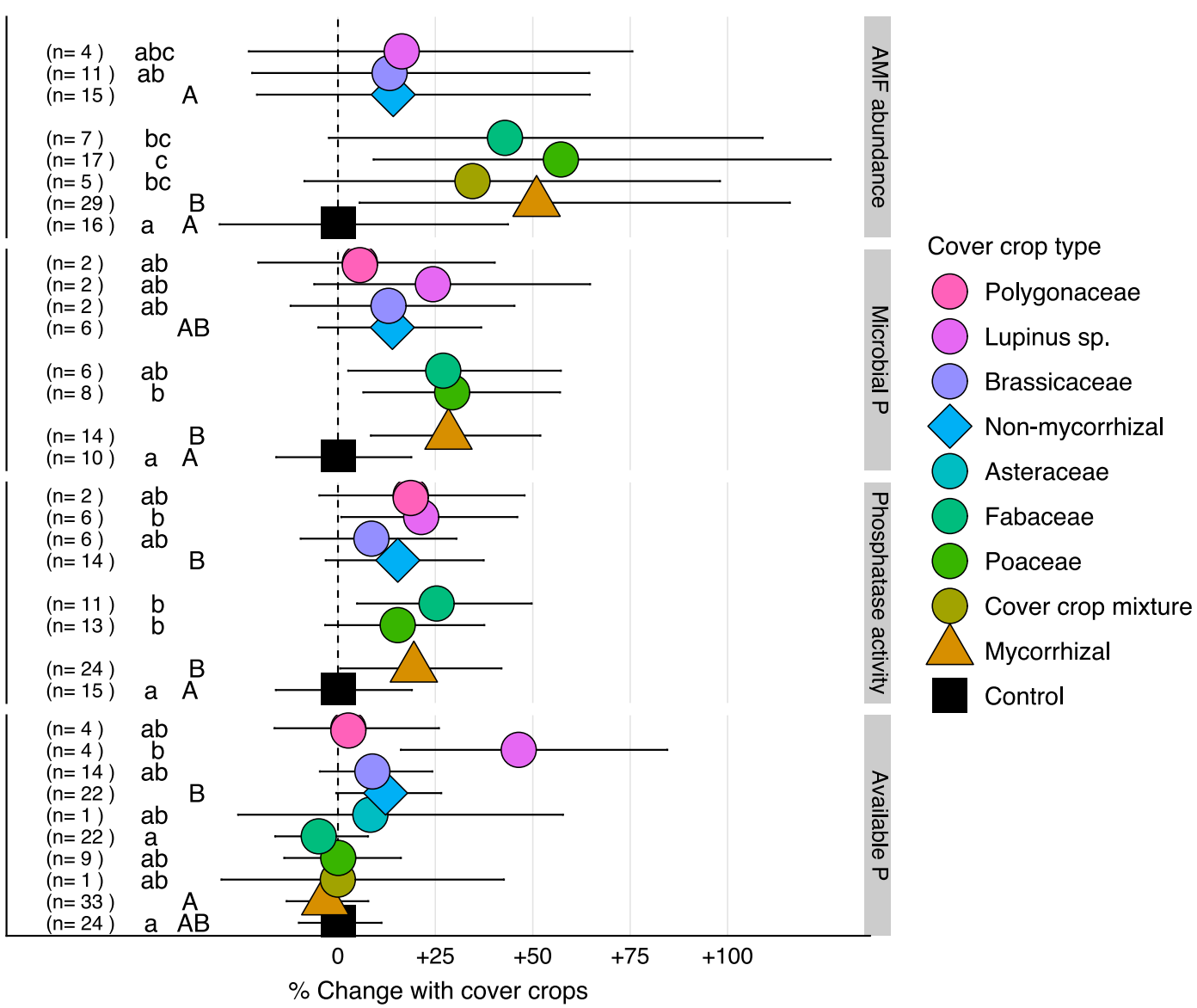

Fig. 6 Soil biological parameters: change in percent abundance of arbuscular mycorrhizal fungi (AMF), microbial biomass phosphorus $(\mathrm{P})$ content, and phosphatase activity as well as available $\mathrm{P}$ after different cover crops, relative to the respective controls. On the left are displayed the number of observations. The lower-case

cover crops, and this is related to their P-acquisition strategies. Maize and wetland rice yields increased more than soybean, cereals or vegetables/cotton/Brassicaceae. The response of maize to other cover crop benefits, especially Fabaceae, has also been seen in other meta-analyses (Alvarez et al. 2017), but the modelled high response in the present dataset may be explained by the inclusion of several studies conducted in low-input agroecosystems. The yield response of wetland rice is not directly comparable with that of other main crops due to the practice of flooding and the fact that all studies were conducted with Fabaceae cover crops. The limited benefit of cover crops to some main crops, i.e. canola, vegetables, and cotton, can be attributed in part to the reduced number of trials and possibly to greater management challenges (i.e. cover crop residues interfering with seedbed preparation) compared with other, more robust, arable crops. letters indicate, for a single main crop type with a Tukey post-hoc test $(p<0.05)$, significant differences among cover crop types (including the control), and the upper-case letters between mycorrhizal cover crops, nonmycorrhizal cover crops and the controls. The corresponding models can be found in Table S3.5

Mechanisms underpinning the $\mathrm{P}$ benefit of cover-crop families

The main crop response was related to both the cover crop species used and the varying mechanisms of plant-microbial interactions. Fabaceae was overall the most effective cover crop family across all conditions and systems (Figs. 4 and 6). This family combines several of the mechanisms of $\mathrm{P}$ benefit: $\mathrm{P}$ uptake and carry-over in an abundant biomass with a high $\mathrm{P}$ concentration that facilitates release in synchrony with the main crop (Fig. 3), and a lasting effect on the soil microbial community (especially for mycorrhizal abundance and phosphatase activity) (Fig. 6). The $\mathrm{N}$ provided by symbiotic fixation provides an additional advantage through the acceleration of residue mineralization. 
Fig. 7 Main crop yield and phosphorus $(\mathrm{P})$ uptake as affected by cover cropping in soils with low and high available $\mathrm{P}\left(\mathrm{P}_{\mathrm{a}}\right)$. The points represent the percentage change of the modeled median (+/- $95 \% \mathrm{CI})$ of the cover crop treatments relative to the controls without cover crops. On the left are displayed the number of observations. The letters indicate significant differences among groups with a Tukey post-hoc test $(p<0.05)$. The corresponding models are presented in Table S3.6

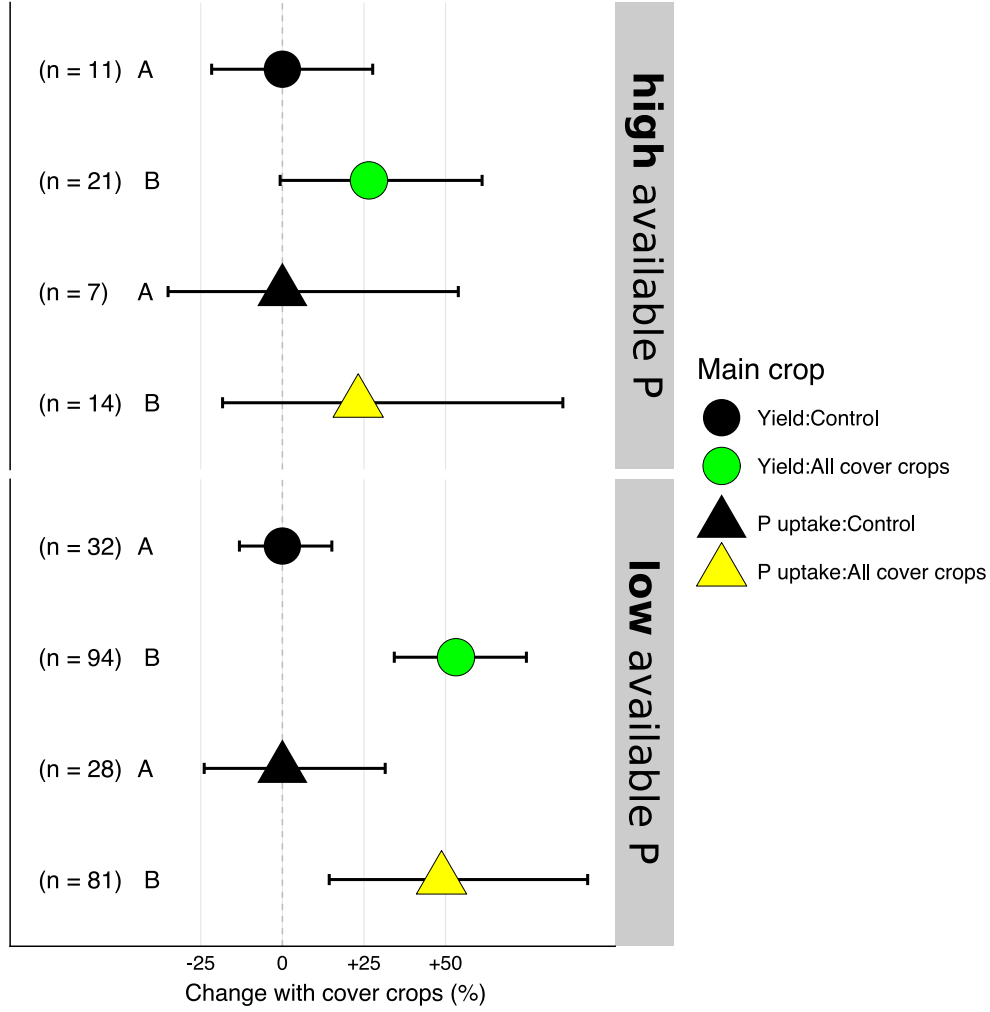

The separation of Lupinus sp. into a group distinct from other Fabaceae is justified: while $\mathrm{P}_{\text {mic }}$ and phosphatase activity were similar, the other (mycorrhizal) Fabaceae were clearly more favorable to mycorrhizal fungi than Lupinus sp. The most striking difference, however, was the effect on the pool of $\mathrm{P}_{\mathrm{a}}$ (Fig. 6). The biochemical modification of the rhizosphere of Lupinus sp. increased the abundance of labile P under the main crop also, but its low biomass and low to intermediate $\mathrm{P}$ concentration probably limited its benefit to the main crops.

The absence of increases in main crop yield or at least $\mathrm{P}_{\mathrm{a}}$ with pure stands of Polygonaceae, mainly Fagopyrum esculentum (buckwheat), was not expected in our meta-analysis, as buckwheat is used as a Pmobilizing species (Boglaienko et al. 2014). Whether or not buckwheat's potential could be improved with other main crops, in a mixture with other cover crop species, or if its beneficial effects were limited by the low biomass observed in the studies included in the meta-analysis, warrants further investigation.

Asteraceae had intermediate positive effects on the main crops, but were tested exclusively as a cover crop for cereals. The species used in the experiments are all potentially mycorrhizal (Wang and Qiu 2006), but we lack detailed data on the soil biological parameters. The high biomass produced by these species is favorable as long as $\mathrm{P}$ concentrations are not too low.

Pure stands of Brassicaceae did not improve P nutrition of the main crop as much as most other families. This was possibly connected to a rather low interaction with the soil microbial community: neither mycorrhizal abundance, nor $\mathrm{P}_{\text {mic }}$ or phosphatase activity were increased significantly under the main crop. For species with high biomass production, such as Brassicaceae and Poaceae, P-cycling via the residue pathway is more important than for other cover crops.

Despite large amounts of $\mathrm{P}$ cycled through the biomass of Poaceae cover crops (Fig. 3), yield benefits for the main crops were limited (Fig. 4). Poaceae were most successful in increasing mycorrhizal abundance and microbial $\mathrm{P}$, and they also enhanced phosphatase activity; negative effects on P-related soil biological parameters could therefore be ruled out. Poaceae produced the greatest quantities of biomass, but had the lowest mean $\mathrm{P}$ concentration of the cover crops, averaging $2 \mathrm{~g} \mathrm{P} \mathrm{kg}^{-1}$. 


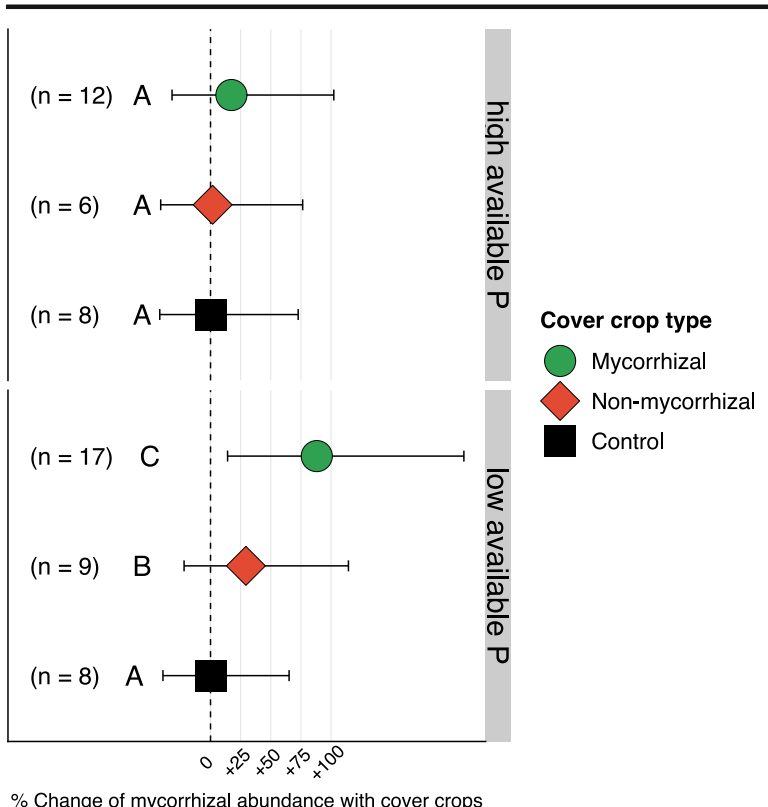

Fig. 8 Effect of cover crops on arbuscular mycorrhizal fungi (AMF) in soils with different $\mathrm{P}$ availability. The points represent the percentage change of the modeled median $(+/-95 \% \mathrm{CI})$ of the cover crop treatments relative to the controls without cover crops. On the left are displayed the number of observations. The letters indicate significant differences among groups with a Tukey posthoc test $(p<0.05)$. The corresponding models are presented in Table S3.7

\section{Decomposition of cover crop residues}

In spite of their high biomass production and positive effects on soil microbial properties, pure stands of Poaceae were among the least successful cover crop families regarding $\mathrm{P}$ benefits for the main crops. This was possibly connected to $\mathrm{P}$ immobilization (EichlerLöbermann et al. 2008), but may have involved other mechanisms as well, as, e.g., incomplete termination or problems with seedbed preparation.

Cover crop biomass and $\mathrm{P}$ concentration determine the amount of $\mathrm{P}$ cycled through the biomass, which can range between 1 and $30 \mathrm{~kg} \mathrm{P} \mathrm{ha}^{-1}$, although 3 to $10 \mathrm{~kg} \mathrm{P}$ $\mathrm{ha}^{-1}$ is more typical, depending on cover crop species and P-availability (Fig. 3). The root:shoot partitioning of $\mathrm{P}$ in cover crops is variable, with 16 to $65 \%$ of the total plant $P$ in the roots (Franchini et al. 2004). The threshold concentration of $\mathrm{P}$ in residues that determines immobilization/mineralization is $2-3 \mathrm{~g} \mathrm{P} \mathrm{kg}^{-1}$. The $\mathrm{P}$ contained in plant residues can be divided into available $\mathrm{P}_{\mathrm{i}}$ and a recalcitrant $\mathrm{P}_{\text {org }}$ pool. The chemical composition of the plant parts changes with the developmental stage of the plant and with $\mathrm{P}$ availability. Cover crop residues are different from harvest residues, as cover crop plants do not reach maturity and $\mathrm{P}_{\mathrm{i}}$ is the major pool in the cells ( $70 \%)$ (Damon et al. 2014).

With tillage, $70-80 \%$ of the $\mathrm{P}$ in legume cover crop residues is released after 6 months, with roots being slightly more recalcitrant (Talgre et al. 2012). The processes responsible for the decomposition of cover crop residues are related to the mineralization of other pools of $\mathrm{P}_{\text {org }}$ in the soil. Cover crops increase phosphatase activity in the soil under a main crop. Although Poaceae, Fabaceae, and lupins tended to increase enzymatic activity more than Brassicaceae did, the plant type seems less important than the practice of cover cropping itself (Fig. 6).

In soils with sufficient $\mathrm{P}$ availability, microbial $\mathrm{P}$ mineralization is not driven by microbial $\mathrm{P}$ requirements, but rather by release of plant-available $\mathrm{P}$ as a by-product of carbon mineralization (Spohn and Kuzyakov 2013b). Current modeling approaches assume that microbial biomass releases $\mathrm{P}$ upon death, and is connected to the decay of the residue biomass through the availability of $\mathrm{C}$ substrates. A single pool for $\mathrm{P}_{\text {mic }}$ and residue $\mathrm{P}_{\text {org }}$ is used, assuming the same decay coefficients (Damon et al. 2014; Varela et al. 2017). Some authors argue that many studies on the decomposition of cover crop residues have used unrealistically large quantities of finely-ground residues and have not taken into account modification of the rhizosphere by the cover crops (Cavigelli and Thien 2003). Additionally, high concentrations of decomposing legume residues transiently increase the $\mathrm{pH}$ in soils with low $\mathrm{pH}$ and SOM, potentially leading to increased $\mathrm{P}$ availability (Vanzolini et al. 2017). Further field studies on residue decomposition dynamics with tight sampling frequencies are necessary. Different experimental setups can shed light on the relative importance of the transfer of $\mathrm{P}$ via the (shoot) cover crop biomass, e.g., removing the cover crop shoots, or by applying cover crop residues to previously unplanted soil (Rutunga et al. 2008; White and Weil 2010; Buyer et al. 2010).

The mechanisms by which the soil microbial community determines $\mathrm{P}$ dynamics during crop residue decomposition are not fully understood (MaltaisLandry and Frossard 2015), nor are the interactions between the microbial community and particular cover crops with their subsequent decomposition dynamics. The decomposer community adjusts to the cover crop species, as decomposable plant residues are produced over the entire growing period by senesced leaves or dead root hairs. Together with root exudates, 
this constant input of substrates constitutes a driver for shifts in microbial community structure, increasing the numbers of fast-growing copiotrophic microbes. Due to the strong impact of nutrient availability, phylogenetic diversity decreases in the vicinity of plant roots (Marilley and Aragno 1999); nevertheless, overall species richness in the field is expected to increase due to increased spatial heterogeneity. In a litterbag study in Brazil, mixtures containing Raphanus sativus with Secale cereale or Avena sativa showed peculiar dynamics, with a delayed increase of $\mathrm{P}_{\text {mic }}$ associated with RNA that could not be explained by the chemical characteristics of the residues alone (de Oliveira et al. 2017). The soil microbial community also influences suppression of weed germination by cover crop residues through selective decomposition of phytotoxic compounds (Moonen and Bàrberi 2006). The positive effects of cover crops on soil fauna (Blanchart et al. 2006) increase decomposition rates and nutrient cycling, probably persisting into the main crop phase. Although we focused on the soil microbial community, the importance of soil fauna (i.e. earthworms) for the shifts in $\mathrm{P}$ dynamics after cover crops should not be underestimated (Roarty et al. 2017).

The relationship between nutrient stoichiometry of the soil, microbial biomass, and plant residues determines microbial colonization and mineralization patterns. Fungi and other microorganisms capable of filamentous growth, unlike unicellular life forms, are capable of translocating nutrients between different compartments (i.e. soil-litter) to compensate for nutrient limitations. This has been demonstrated for $\mathrm{C}$ and $\mathrm{N}$ (Frey et al. 2003), and seems also plausible for $\mathrm{P}$. Therefore, and bearing in mind the reduced damage to hyphae by reduced soil disturbance, fungal-driven decomposition probably dominates in no-till systems, where residues have less direct contact with the soil. Although no-till significantly increases fungal abundance, the interaction between the factors tillage and cover crop had no significant effect on the ratio of saprotrophic fungi:total bacteria in a long-term experiment under continuous cotton in Tennessee, USA (Mbuthia et al. 2015).

Nutrients other than $\mathrm{P}$ also need to be taken into account (Weerakoon et al. 1992), as residue mineralization dynamics and $\mathrm{P}$ release can be driven by $\mathrm{N}$ availability. An increased supply of $\mathrm{N}$ from a leguminous cover crop may permit the main crop to exploit its $\mathrm{P}$-acquisition potential, resulting in increased $\mathrm{P}$ uptake.
In field experiments, this effect is difficult to control, especially when a significant proportion of nutrients is contained in the cover crop root biomass. Cover crops can cycle substantial amounts of nutrients (potassium $(\mathrm{K})$, magnesium $(\mathrm{Mg})$, and calcium $(\mathrm{Ca}))$ in their biomass (Wendling et al. 2016), and increase the availability of K (Cardoso et al. 2013). Descriptions of negative effects on plant nutrition are scarce and remain hypothetical. In some situations, the biomass pathway described in this paper could increase availability of potentially toxic elements, e.g., Mn, and lead to growth depression (Horst et al. 2001). Other researchers have considered the possibility that high levels of $\mathrm{NaHCO}_{3}$ $\mathrm{P}_{\mathrm{i}}$ near the surface could induce copper $(\mathrm{Cu})$ and zinc (Zn) deficiencies in conservation agriculture systems (Dube et al. 2014).

Arbuscular mycorrhizal fungi: early colonization assists crop P uptake by soil exploration

The strong increase, around 50\%, in AMF abundance after mycorrhizal cover crops (Fig. 6), is important for the mechanisms of $\mathrm{P}$ benefit to the main crop. Most crops, with some notable exceptions, i.e. Brassicaceae, Polygonaceae, and Lupinus sp., can form symbioses with AMF with multiple benefits (Koide and Mosse 2004). AMF hyphae provide some of the functions of root hairs, especially in plant species with thick roots and very few or short root hairs, leading to exploration by plants of an increased volume of soil (Smith et al. 2011). Some functions and mechanisms of AMF symbioses are well known, although several fundamental issues remain unanswered. In AMF-colonized plants, the fungi are usually involved in $\mathrm{P}$ uptake with inhibition of a direct pathway via roots, and there may not always be positive growth responses (Smith et al. 2015; Ryan and Graham 2018).

There is no conclusive evidence that AMF-colonized plants are able to take $\mathrm{P}$ from soil sources that cannot be accessed by the roots themselves; rather they increase the soil volume from which the same $\mathrm{P}$ pools can be acquired (Smith et al. 2015). Direct release of phosphatases by AMF with a significant contribution to plant $P$ uptake is under discussion (Joner et al. 2000). However, the substantial C input from plants through mycorrhizal hyphae extends our concept of a modified rhizosphere to a much greater soil volume, and the microflora of the 
mycorrhizosphere may play a critical role in $\mathrm{P}$ acquisition (Bending et al. 2006).

Mycorrhizal cover crops tended to increase main crop yield and $\mathrm{P}$ uptake more than non-mycorrhizal plant species did (Fig. 4), and AMF abundance is positively related to main crop yield and P uptake (S3.9 Models 9.1 and 9.2). With phosphatase activity, this direct relationship was not found. However, methodological deficiencies and the small number of studies may have resulted in a high variance. Due to sorption and stabilization onto soil particles, the enzymatic activity of a soil also reflects the recent history of a soil. This must be taken into account when interpreting the results of the meta-analysis. Samples were taken after termination of the cover crop or under the main crop. Therefore, the enhanced activity relative to that of the fallow control treatments corresponded either to residual phosphatases released by the cover crop roots, to changes in abundance or structure of the soil microbial community, or to an overall substrate-driven increase in phosphatase activity due to P-rich cover crop residues in the soil. Increases in phosphatase activity mirrored the effect of cover crops on microbial biomass $\mathrm{P}$, indicating a potential microbial origin of the enzymes.

A mycorrhizal cover crop can transfer its ability to access $\mathrm{P}$ in the soil to the main crop in the form of mycorrhizal inoculum (hyphae or spores in the soil). Although the AMF-plant symbiosis is unspecific and larger plants may be simultaneously colonized by different mycorrhizal fungal species, there are some plantAMF genotype combinations that are more efficient than others (Jansa et al. 2011). Molecular techniques make it possible to describe AMF diversity associated with specific cover crops (Sharrock et al. 2004), and increases in richness in the main crop have been reported (Ramos-Zapata et al. 2012). However, current knowledge gaps regarding the connection between AMF community assemblage and species function constrains the effective translation of this information into specific cover crop species recommendations.

The build-up of AMF inoculation potential benefits only AMF-competent main crops, and the ability of the main crop to take advantage of earlier increased mycorrhization by previous cover crops determines the P benefit (Bittman et al. 2006). For maize, a positive relationship between mycorrhizal colonization and plant biomass or P content was found in both our aggregated dataset and several single studies (White and Weil 2010; Njeru et al. 2014). Cavigelli and Thien (2003) reported Lupinus albus unexpectedly decreased sorghum $\mathrm{P}$ uptake in a pot experiment, although $\mathrm{P}$ uptake and biomass was the highest of the tested winter cover crop species; a possible explanation was that lupin was the only non-mycorrhizal crop in the study. However, the lower potential for AMF inoculation cannot have been the only reason, as non-mycorrhizal Brassicaceae performed better, whereas mycorrhizal Poaceae combined poorly.

It is important to bear in mind that non-mycorrhizal crops have evolved special strategies for $\mathrm{P}$ acquisition. Non-mycorrhizal families can be broadly classified into Brassicaceae and Proteaceae groups, which evolved in P-rich and severely P-impoverished environments, respectively (Lambers and Teste 2013). Raphanus sativus var. oleiferus (oilseed radish) exudes large amounts of acid phosphatase and other rhizodeposits into the rhizosphere (Kunze et al. 2011); the exceptional P-mining strategies of Lupinus sp. have been described above. The impact of these P-acquisition strategies must be considered when designing site-specific crop rotations that include cover crops.

The meta-analysis also showed an unexpected slight tendency toward increased mycorrhizal abundances, after non-mycorrhizal cover crops. However, species of plant families labeled as "non-mycorrhizal" can be infected at low levels by AMF (Lambers and Teste 2013). Another possibility is that higher herbicide usage in the control treatments decreased AMF abundance because of direct toxic effects (Trappe et al. 1984; Giovannetti et al. 2006) or by fewer weeds acting as mycorrhizal hosts (Oehl et al. 2003).

The use of cover crops to build up the inoculum potential of beneficial microorganisms, including AMF, has the capacity to considerably improve soil fertility (Galvez et al. 1995; Boswell et al. 1998; Bagayoko et al. 2000; Kabir and Koide 2002; Lehman et al. 2012), although apparently not in all agroecosystems (Sorensen et al. 2005; Higo et al. 2014). In a study in USA, 31 years of Vicia villosa cover cropping decreased mycorrhizal abundance relative to wheat or no cover crop, with some responses associated with high $\mathrm{N}$ rates (Mbuthia et al. 2015). Also, in fields with a history of mycorrhiza-enhancing cropping techniques (i.e. rotation dominated by mycorrhizal crops, no-till), cover crops may not increase the mycorrhization of the main crop further (Turmel et al. 2011). In agricultural soils very low in mycorrhizal abundance, cover crops may fail to increase the inoculum potential above a minimum threshold necessary to 
benefit plant growth (Douds et al. 2011). On the other hand, cover crop mixtures and a strategic AMF-build-up may be especially important in this context (Lehman et al. 2012).

Weeds growing during the off-season may also result in benefits for the main crop; e.g., Taraxacum officinale (dandelion) is a good host for overwintering mycorrhizal fungi (Kabir and Koide 2000). However, some weeds induce negative changes in the microbial community (i.e. a decrease in AMF) and enhance their own competitive advantage over the crops (Wortman et al. 2013). Costs of seeds and labor for cover crop establishment have to be included in evaluating their potential to outperform weeds, and, above all, their easy termination (Wang et al. 2008). Also, management and application form of cover crops determines their effect on $\mathrm{AMF}$, as fresh red clover residues, directly incorporated or used as a mulch layer, result in greater abundance of AMF compared with processed residues (biogas slurry, compost) (Elfstrand et al. 2007). The discovery of significant advantages to seedlings conferred by early establishment of symbioses with mycorrhizal fungi or Psolubilizing bacteria has prompted the development of commercial and on-farm produced inocula for plant growth promotion (Douds et al. 2010). Also, combining cover crops with a simultaneous inoculation of microorganisms has been investigated (Cui et al. 2015).

It is experimentally challenging to separate the direct benefits of improved $\mathrm{P}$ availability from other plantmicrobial interactions and indirect plant growthpromoting effects. Microbes have multiple effects on plant health via plant pathogen suppression as well as on nutrient cycling and plant nutrition (Bagayoko et al. 2000; Bashan et al. 2013). Cover crop species differ substantially in their root-associated fungal communities (Benitez et al. 2016), suggesting opportunities for management of beneficial and pathogenic fungi, although contradictory evidence has been reported (Turrini et al. 2016). Nutrient uptake and crop yield are often limited by biotic stress. Increased aboveground biodiversity (i.e. by cover cropping) can suppress soil pathogens, thus promoting plant growth. Some cover crop species can be used for specific pest management, whereas others may serve as hosts for pests (Ratnadass et al. 2012). In view of the multiple ecosystem functions of soil microbes, Fester and Sawers (2011) advocated a holistic approach of increasing biodiversity through agronomic management as opposed to a reductionist approach focusing on single species.
Microbial P as a significant pool

Increases in microbial $\mathrm{P}$ of around $25 \%$ with Poaceae and Fabaceae cover crops (Fig. 6) are worth further discussion, because $\mathrm{P}_{\text {mic }}$ constitutes an important pool in soil due to its relatively fast turnover and subsequent availability for plants. However, due to the small number of studies, we did not detect a significant effect of $\mathrm{P}_{\text {mic }}$ on main crop yield and $\mathrm{P}$ uptake. Interestingly, the mycorrhizal cover crop types tended to enhance $\mathrm{P}_{\text {mic }}$ more than the non-mycorrhizal species. The pool of $\mathrm{P}_{\text {mic }}$ in agricultural soils typically constitutes $5-70 \mathrm{~kg} \mathrm{P} \mathrm{ha}^{-1}$, with turnover times of a few months, depending on management and C inputs (Oehl et al. 2001).

Phosphorus in microbial cells is present mostly in the form of nucleic acids, but also as small P-containing esters, free $\mathrm{P}_{\mathrm{i}}$, and phospholipids of cell membranes. The nucleotide content can vary greatly, depending on the growth rate of the cell; surplus $\mathrm{P}$ can be stored as polyphosphates (Harold 1966; Stewart and Tiessen 1987). When comparing the nutrient stoichiometry of soils, microbial biomass, $\mathrm{P}_{\text {mic }}$ appears to be closely linked to overall microbial biomass (Cleveland and Liptzin 2007). However, in agricultural soils, the microbial C:P stoichiometry may, in response to soil fertility and management, exhibit some plasticity and be affected by the availability of $\mathrm{P}$ for the main crop.

Cover-cropping frequency was a greater driver of increases in microbial biomass than compost application, increasing the abundances of Pseudomonas and Agromyces species, including species that are important biological control agents and plant growth-promoting rhizobacteria (Brennan and Acosta-Martinez 2017). In a study in semi-arid Kenya, microbial C, N, and P were strongly increased by different Brachiaria species (Gichangi et al. 2016). In another study, cover cropping was far more important than the measured environmental variables (moisture, temperature, $\mathrm{pH}$ ) in controlling soil microbial community structure (Buyer et al. 2010). Relative abundance of Gram-positive bacteria was decreased by cover cropping, probably connected to their lower ability to use labile $\mathrm{C}$-inputs compared with other microbial groups. In a field experiment in Sweden, direct incorporation of a red clover crop enhanced and sustained microbial biomass and soil enzyme activities more than did processed forms of green manure applied as biogas slurry or compost (Elfstrand et al. 2007).

The application of isotopic dilution methods has revealed that microbial immobilization and remineralization, 
rather than mineralization of non-living organic $\mathrm{P}$, represents most of the gross organic $\mathrm{P}$ mineralization flux (Bünemann 2015). Sorption/desorption processes dominate in agricultural soils low in microbial biomass. Immobilization/mineralization dynamics are closely linked to overall microbial growth, but trophic interactions should not be overlooked, as amoebae and other bacteria-grazing microfauna are responsible for the remineralization of $\mathrm{P}_{\text {mic }}$ (Cole et al. 1977). Cover crops increase the abundance and diversity of microfauna (Blanchart et al. 2006) which restricts long-term microbial immobilization during the decomposition of plant litter. Given the close relationship between Phaseolus vulgaris yield and $\mathrm{P}_{\text {mic }}$, microbial biomass $\mathrm{P}$ was proposed as an indicator of soil $\mathrm{P}$ availability on P-sorbing Andosols in Japan, instead of the widely used Truog-P (Sugito et al. 2010).

Mobilized and mineralized $\mathrm{P}$ is often intercepted by microorganisms before plant roots can take it up (Joner et al. 2000). Although in managed agroecosystems crop yield is the primary objective, some interactions between crops and other organisms, seen as competitive and undesirable in the short term, may have, in principle, longerterm favorable properties (i.e. SOM build-up, pathogen resistance). Competition for available nutrients determines the outcome of the plant-microbe relationship at all levels, from the more opportunistic microbes in the rhizosphere to the mutualists, as even AMF-symbioses can range from being highly beneficial for both partners to 'parasitic' (Johnson et al. 1997). In addition to mycorrhizal fungi, there are many other plant-associated organisms that affect $\mathrm{P}$ uptake. One example of the very complex interactions between microorganisms and plants are mycorrhiza-helper bacteria, which facilitate the establishment of the symbiosis (Frey-Klett et al. 2007).

Cover crops under different soil-management strategies

The effects of cover crops vary greatly, and some studies report no or even negative effects (Kuo et al. 2005; Takeda et al. 2009b; Rick et al. 2011). This has been due, in some cases, to intrinsic agronomic conditions related to low cover crop biomass or absence of a significant $\mathrm{P}$ limitation on experimental plots. Rick et al. (2011) did not find effects of cover crops on labile soil $\mathrm{P}$ fractions, wheat biomass, or $\mathrm{P}$ concentration, despite differing biomass and $\mathrm{P}$ concentrations of the cover crops. However, as neither cover crops nor rock phosphate fertilization resulted in substantial yield responses, it is possible that the lack of positive results was due to a combination of moderately high soil $\mathrm{P}$ levels, $\mathrm{N}$ limitation, and low precipitation. Also, studies in Brazil on strongly P-sorbing acidic soils, where cover crops often increase labile and moderately labile $\mathrm{P}$ pools while decreasing residual $\mathrm{P}$, did not always show the expected increases in terms of $\mathrm{P}$ uptake (Almeida and Rosolem 2016). After 3 years in a Brazilian Hapludox under no-till, Avena strigosa (black oat), Vicia sativa (common vetch), and Raphanus sativus (fodder radish) as cover crops cycled $\mathrm{P}$ from the non-labile and moderately labile $\mathrm{P}$ pools through their biomass without reducing labile P fractions; maize yields were also not affected (Pavinato et al. 2017). Increased $P$ availability was also not consistently translated into improved main crop performance (Pavinato et al. 2017). In other studies, however, although labile $P$ fractions were not affected, yields were increased (Murungu et al. 2011b; Dube et al. 2014), or traditional soil $P$ tests failed to detect the shift in P dynamics by cover crops (Takeda et al. 2009a, 2009b). Reasons for this variability in response are manifold, and reflect both methodological limitations when assessing $\mathrm{P}$ dynamics and the diversity of the studies' designs, as well as abiotic and biotic factors. This points to practical problems in agricultural management that often hamper the successful exploitation of cover crop benefits. Recurrent calls for geneticallyengineered crops for improved $\mathrm{P}$ efficiency, e.g., in Hunter et al. (2014) overestimate our understanding of the complex rhizosphere processes involved, while existing agricultural management options are underrated.

The importance of site conditions and agricultural management in controlling both growth of cover crops and main crops and the complex mechanisms of their interactions with $\mathrm{P}$ explains some of the variation in results of the studies included in the metaanalysis. However, knowledge of the impact of soil $\mathrm{P}$ status and different management approaches will not only aid in the interpretation of field experiments, it will also provide many tools for adapting cover crop effects to the specific needs of local agroecosystems. Cover-cropping management can be used according to site conditions in many ways, e.g., by appropriate combinations of cover crop species/mixtures with the crop rotation (e.g., de Oliveira et al. 2017), and by fertilization and tillage (e.g., Mbuthia et al. 2015; Teles et al. 2017). Other management decisions, such as seeding rate (Brennan et al. 2009), seeding and termination date (Nascente et al. 2013), and 
termination technique (Dorn et al. 2013), extend the opportunities for fine-tuning cover crop performance and $\mathrm{P}$ effect. However, as cover crops provide multifunctional tools when enhancing performance for a given function, there can be trade-offs with other functions (Mirsky et al. 2012). For example, on soils with low $\mathrm{P}$ availability, a highly-efficient scavenging cover crop with an extensive rooting system that takes up P from the same pools as the main crop could lead to soil $\mathrm{P}$ immobilization when the easily-available $\mathrm{P}$ is depleted and immobilized in recalcitrant plant residues. Management options could include selection of a different cover crop species/mixture or a later sowing/earlier termination date to reduce the recalcitrance of cover crop residues.

\section{Soil $\mathrm{P}$ and fertilization}

Phosphorus dynamics, and the effect of cover crops on them, are strongly influenced by the soil, specifically by the size of easily- and sparingly-available $\mathrm{P}$ pools. The meta-analysis supports the hypothesis that cover crop $\mathrm{P}$ benefits are more evident in soils poor in $\mathrm{P}_{\mathrm{a}}$ than on sites with higher $\mathrm{P}_{\mathrm{a}}$ (Fig. 7). Also, interactions between cover crops and the soil microbial community are influenced by soil P status: the increase in AMF abundance after mycorrhizal cover crop use is much greater in soils low in $\mathrm{P}_{\mathrm{a}}$ (Fig. 8); phosphatase activity shows a similar pattern (data not shown). These results are promising, and the P-mobilizing properties of different cover crop species should be further investigated, specifically in soils high in $\mathrm{P}_{t}$, but low in $\mathrm{P}_{\mathrm{a}}$. However, soils very low in $\mathrm{P}_{\mathrm{a}}$ often also have other fertility problems. Soil quality affects the beneficial effects of cover crops in several ways. Although very fertile or well-managed soils are difficult to improve further with cover crops (Turmel et al. 2011), cover crops require adequate initial soil fertility to effectively improve $\mathrm{P}$ cycling and inputs may be necessary to obtain a functional cover crop (Jensen et al. 2005). Examples of useful soil quality parameters are available $\mathrm{P}$, microbial biomass $\mathrm{C}\left(\mathrm{C}_{\text {mic }}\right)$, and the $\mathrm{C}_{\text {mic }}: \mathrm{C}$ ratio (Koné et al. 2008). Depending on local economic circumstances, a good use of expensive inorganic $\mathrm{P}$ fertilizer might be to apply $\mathrm{P}$ sources to cover crop legumes; this would improve their ability to benefit from existing soil $\mathrm{N}$ as well as residually applied P (Carsky et al. 2001). There are substantial synergies between $\mathrm{P}$ application and $\mathrm{N}$ fixation by leguminous cover crops (Weerakoon et al. 1992).
Several studies that did not find a consistent effect of cover crops on soil $\mathrm{P}$ pools led some authors to argue that the P-mobilizing properties of legumes are more efficient for low-input agriculture on soils with low $\mathrm{P}$ availability than for systems where $\mathrm{P}$ availability is higher and $\mathrm{P}$ limitation weaker (Maltais-Landry et al. 2015). We agree with this line of reasoning and suggest consideration of $\mathrm{P}$ reserves to complement the labile $\mathrm{P}$ assessed in standard soil $\mathrm{P}$ testing when selecting and evaluating cover crops. The classification into high- and low-P soils is a simplification, which becomes clear when treating soils high in $\mathrm{P}_{\mathrm{t}}$ but very low in $\mathrm{P}_{\mathrm{a}}$, as in southern China or Andosols in Chile and Japan. On these soils, P-mobilizing cover crops would be of particular interest. Because cover crop P benefit reflects mainly biological processes, these may not be assessed properly with methods designed to predict the effects of inorganic $\mathrm{P}$ fertilization. In high-input systems with high $\mathrm{P}$ availability, tillage, and additional $\mathrm{P}$ fertilization, cover crops often do not increase yields significantly over the control (data not shown).

A positive interaction of cover crops with $\mathrm{P}$ fertilization is in part related to the fertilizer type used. Cover crops may increase the availability of the $\mathrm{P}$ contained in organic fertilizers or phosphate rock (Ca-P/apatite). In particular, proton- and organic anion-exuding plants such as Fagopyrum esculentum or legumes, but also green manure from Tithonia diversifolia, dissolve calcium (Ca)-P, which is important for organic farmers on calcareous soils (Arcand et al. 2010) and farmers relying on phosphate rock on acid soils (Somado et al. 2003; Ikerra et al. 2006; Oikeh et al. 2008; Opala et al. 2010). However, this effect has not always been found (Rick et al. 2011). Plant-microbial interactions likely play a role in fertilizer effects (Bah et al. 2006). Indications of an interaction between P-fertilizer type (soluble P vs rock phosphate) and cover cropping has also been shown in some studies (Almeida and Rosolem 2016), but was not considered in the present meta-analysis. Plant species respond differently to fertilizer types. Brassica oleracea showed a dramatic response to an otherwise unreactive, Fe-rich, igneous phosphate rock, but this source was ineffective for leguminous cover crops and maize; the following maize yield was not increased by cabbage (Weil 2000). Aluminium phosphate is naturally present in some rock phosphates and soils, but may be inadequate for plants that rely on proton exudation for P-acquisition, as pointed out by Pearse et al. (2006), comparing wheat and lupin in a pot 
experiment. The interactions between fertilizer type, cropping system and soil are complex (Romanyà and Rovira 2009), and require, therefore, site-specific recommendations.

Some studies have shown a more efficient use of $\mathrm{P}$ when added with organic amendments (EichlerLöbermann et al. 2008; Maltais-Landry et al. 2015), but not others (Takeda et al. 2009a). Under the condition of added $\mathrm{C}$ sources, effects of direct competition for $\mathrm{P}_{\mathrm{a}}$ by microbial immobilization are at variance with a rate increase in cycling of organic P. The properties of the amendment must be taken into account when selecting the cover crop. Fertilizers with high levels of $\mathrm{P}_{\mathrm{a}}$ should be combined with species such as Raphanus sativus oleiformis (oil radish) that maximize uptake and biomass production; species with mobilization traits, such as phacelia would be suitable for sites with lessavailable P sources (Bachmann and Eichler-Löbermann 2010).

Continuous developments in alternative and innovative cover-crop systems have the potential to increase sustainability of intensive systems such as high-input horticulture (Brennan 2017). In systems with substantial organic inputs (i.e. manure), P availability is usually not a concern, and other cover crop effects are desired (prevention of nutrient leaching, weed suppression, C input). An overlooked property of cover crops regarding $\mathrm{P}$ dynamics is connected to the inherent imbalance of the N:P ratio in animal manure: legume cover cropping permits lower rates of manure application by supplying $\mathrm{N}$ to subsequent crops (i.e. supporting P-based application rates), reducing the $\mathrm{P}$ excess of $\mathrm{N}$-based organic fertilization (Kleinman et al. 2001; Cherr et al. 2006). A special, but not uncommon, situation is the management of large quantities of manure from industrial animal farms by field application in combination with cover crops (Rowe et al. 2006).

Cover crops can be used in watershed management for the reduction of P-runoff (Villamil et al. 2006; Geleta et al. 2006). Legumes are generally appreciated for their ability to mobilize poorly-available $\mathrm{P}$, whereas grasses are more often used as "catch crops", scavenging the available nutrients and reducing losses (Maltais-Landry et al. 2015). The authors concluded that, in soils with low P-sorbing capacity, P transfer via the cover crop biomass of grasses is more effective than that of legumes, which more strongly modify their rhizosphere. Systems at risk of $\mathrm{P}$ losses usually also have problems with N losses (Sharpley and Smith 1991; Aronsson et al.
2016; Brennan 2017), making a focus on grasses instead of legumes meaningful.

\section{Cover crop mixtures}

Cover crop mixtures are, in terms of main crop performance, superior to monoculture cover crop species (Figs. 4, 5 and 6); however, most studies used maize as a main crop, which is highly responsive to cover cropping, and also the total number of trials was low. It is difficult, therefore, to draw general conclusions about cover crop mixtures due to the inherent differences in systems depending on the specific components. Mixtures frequently outperform single species in terms of biomass production and $\mathrm{P}$ uptake ( $\mathrm{Li}$ et al. 2007, 2014; Messiga et al. 2016), in addition to the positive influence plant biodiversity exerts on soil biology. Other plants growing in close association with P-mobilizing plants confer additional benefits through intercropping or undersowing, and may also increase access to sparingly-soluble $\mathrm{P}$ (Li et al. 2007). Cereal-legume mixtures are among the most widely used and studied (Tarui et al. 2013), due to both their ecological importance and to the availability of practical management expertise with these combinations, because of their use in fodder production. An important benefit of this association is increased $\mathrm{N}$-fixation by the legume driven by the $\mathrm{N}$ demand of the cereal (Høgh-Jensen and Schjørring 1997), N transfer (Brophy et al. 1987), and facilitative interactions via root exudates, as detected between Zea maize and Vicia faba (Li et al. 2016). In cereal-legume mixtures, the cereal component benefited more from the intercropping association than the legumes, reflected in the observed shift in composition towards a higher proportion of grasses over time (Maltais-Landry 2015). However, the legume productivity may also be enhanced by intercropping, because Zea maize improved Fe nutrition of Arachis hypogaea (peanut) in a calcareous soil (Zuo et al. 2000; Zuo and Zhang 2008). In mixtures, there are several trade-offs that have to be balanced; e.g., easily decomposable cover crop residues improve nutrient availability for the main crop, but result in lower weed suppression and less SOM production in comparison with more recalcitrant plant residues (Tarui et al. 2013).

Desirable mixtures of species with complementary functions have a huge potential to increase the benefit of cover cropping, as, e.g., Brassica napus (fodder rape) and Lupinus albus (Little et al. 2004). There is also the 
advantage of the biofumigant properties of Brassica species and its biomass, as well as the $\mathrm{P}$ mobilization of Lupinus sp. (although a mycorrhizal component could enrich the combination). The combined use of a mixture of rye and oat as winter-hardy and winter-killed species also yielded positive results in temperate climates (Kabir and Koide 2002). The transfer of nutrients from dying roots to living roots via $\mathrm{AMF}$, as suggested by Newman and Eason (1989), should also be taken into consideration.

In the meta-analysis, AMF abundance following mixtures containing non-mycorrhizal Brassicaceae tended to be only slightly less than that with pure Poaceae or Fabaceae stands. This suggests that one mycorrhizal partner in a mixture is capable of compensating for the lack of mycorrhizal association of the other. An experiment in mid-Atlantic USA showed that a pure stand of Raphanus sativus var. longipinnatus (forage radish) did not have a negative effect on AMFcolonization, but a pure stand of rye showed a higher rate of colonization than the mixture rye-forage radish. Further research is necessary to determine whether or not Brassicaceae inhibit the extent to which Poaceae are colonized by AMF (White and Weil 2010). As for potentially adverse effects resulting from nonmycorrhizal and mycorrhizal plant species, there are indications that members of the Proteaceae type exhibit fewer competitive interactions than Brassicaceae types (Gardner and Boundy 1983; Lambers and Teste 2013; Lambers et al. 2018).

The plethora of possible combinations and proportions in cover crop mixtures is difficult to handle experimentally. Even studies with more than four species are scarce, although a systematic and simultaneous screening would be important for the selection of appropriate mixture candidates (Horst et al. 2001; Oikeh et al. 2008; Wendling et al. 2016). The selection and testing of innovative cover crop species requires more largescale projects, such as OSCAR (Crossland et al. 2015), or the 2017 started EU-project REMIX. There is substantial variation, even among genotypes, regarding Puptake efficiency and subsequent main crop growth (Jemo et al. 2006; Rose et al. 2010a; Pang et al. 2018b). Likewise, site conditions are important, because in an acidic soil, root growth determined P uptake, whereas in an alkaline soil malate exudation was probably the more important parameter (Rose et al. 2010a). With respect to soil biological properties, a truly novel and strategic experimental approach is necessary to assess the multiple combinations of cover crop mixtures.

The systematic use of plant traits that interact with $\mathrm{P}$ dynamics, as proposed by Wendling et al. (2016), is already used for other cover crop functions (Damour et al. 2014), and constitutes an important step toward increasing the comparability of trials.

Interactions of cover crops and tillage

Cover cropping tends to have greater positive effects on main crop performance in systems under reduced tillage/no-till than under conventional tillage (Fig. S6). Systems using reduced tillage benefit from the inclusion of cover crops due to weed control, nutrient release, and improved soil structure, together with synergies between both practices regarding soil biological activity. Tillage regime can vary in intensity (shallow/ non-inversion) and frequency (up to no-till), affecting, mainly in two ways, the processes by which cover crops influence soil $\mathrm{P}$ dynamics. First is litter distribution; tillage mixes plant residues into the soil, whereas no-till leaves the nutrient-rich residues on the top. Second, tillage regime changes the soil biota, because organisms differ in their sensitivity to soil perturbation.

Cover crops and no-till benefit soil fauna, which are important for residue decomposition, because their feeding activity fragments and buries litter, increasing the surface for microbial decay. Earthworms increase P availability and their interaction with cover crops deserves further attention (Vos et al. 2014). In tropical and arid areas, termites fulfill important functions in nutrient cycling (Rückamp 2011). On the other hand, under conventional tillage, the greater area of plant residue contact with soil increases the decomposition rate, but can lead to P sorption (Tiecher et al. 2012b). The choice of cover crop can have additional effects, e.g., with the release of isothiocyanates by tilled residues of Brassica juncea (Indian mustard) used as biofumigants, possibly increasing negative effects on mycorrhizal-inoculum potential (Njeru et al. 2014). Under no-till, a forage radish cover crop did not negatively affect mycorrhization of maize (White and Weil 2010).

Balota et al. (2014) found that several microbial parameters increased under cover crops, both under no-tillage and under conventional tillage in a Brazilian oxisol. There was a greater relative increase with cover cropping under conventional tillage, although total microbial abundance and activity remained 
higher under no-tillage when the entire profile was taken into account. The higher metabolic efficiency (lower $\mathrm{qCO}_{2}$-values) indicated that winter cover crops and zero tillage resulted in a more stable system. In the USA, no-till plots increased levels of Gram-positive bacteria, actinomycetes, AMF, and enzymatic activity, whereas tillage enhanced the abundance of saprotrophic fungi and provided a greater total microbial biomass. The cotton yield was greatest after Vicia villosa under no-till (Mbuthia et al. 2015).

One of the principal reasons for the inclusion of cover crops in temperate agroecosystems is the alleviation of soil compaction, which in turn expands the effective rooting zone, benefiting main crops possessing weaker root systems (Calonego and Rosolem 2010). In this context, the property of Raphanus sativus, the so called "tillage radish", deserves further attention, as it produces a strong taproot that decays during the winter and leaves distinct biopores in the surface soil, potentially leading to locally greater P-availability (White and Weil 2011).

Cover crop residues at the soil surface can delay soil warming in spring, and, therefore, the onset of microbial activity; this constrains the use of mulches in cold climates (Sarrantonio and Gallandt 2003). The increased soil water content under mulch layers can also constitute a problem in wet years (White and Weil 2010). Some studies suggest that cover crops have only limited potential to decrease P losses under the wet and cold climatic conditions of northern Europe, as dissolved organic $\mathrm{P}$ leaching over winter may outweigh reductions in erosion losses when plant residues experience several freeze-thaw cycles in the field (Bergström et al. 2015; Aronsson et al. 2016; Kirchmann and Wessling 2017). However, cover crops that were incorporated into the soil during winter did not increase $P$ leaching in a study in Belgium (Vanden Nest et al. 2014); similarly, at least in milder Nordic climates, winter-hardy cover crops could be an option.

The termination method

When cover crops do not die off via natural causes (e.g., frost or drought), a termination step is required. The most widespread method is a termination herbicide, usually glyphosate. However, this practice has been criticized because of undesirable side effects on the agroecosystem and the environment (Johal and Huber 2009; Yamada et al. 2009; Mamy et al. 2016). Glyphosate may also reduce main crop yields when applied too close to the main crop seeding date (Nascente et al. 2013) or it may interact with P-fertilizer application (Rose et al. 2018). Termination can also be mechanical, by tillage of varying degrees of intensity, mixing the plant residues with the soil, or by flailing, disking or rolling the shoot biomass, resulting in a mulch layer that covers the soil surface. The use of roll-choppers requires exact timing to be effective, but can be an adequate alternative to glyphosate (Creamer and Dabney 2002; Dorn et al. 2013). The termination step interacts with the temporal dynamics of the residue mineralization, important for synchronization of nutrient release with the requirements of the main crop (Zibilske and Makus 2009; Murungu et al. 2011a; Damon et al. 2014). The achievement of desirable $\mathrm{C}: \mathrm{N}: \mathrm{P}$ ratios with timely termination may be constrained by field accessibility related to soil water content (Odhiambo and Bomke 2007). The cover crop species should be adapted to variations in sowing and termination dates in order to achieve high biomass and nutrient content, which does not necessarily follow a linear pattern (Anugroho et al. 2009). Cover crops are usually terminated between one and a few weeks before planting the main crop in cases where they are not winter-killed. With chemical termination, a certain time for pesticide inactivation needs to be taken into account.

In some rotations, a cover crop (e.g., white clover before maize) may simply be clipped and permitted to regrow as living mulch, conferring high AMF inoculation potential and improving $\mathrm{P}$ nutrition (Deguchi et al. 2007). An interesting approach for integrated croplivestock systems consists of cover crop termination by grazing (Clark 2008), which can increase P efficiency under adequate management (Costa et al. 2014). Nutrient transfer by cut and carry use of green manure cover crops on improved fallow fields may lead to nutrient impoverishment in low-input systems. Shrub species with high litter and root production, such as Tithonia diversifolia, may be advantageous in these situations (Rutunga et al. 2008). Burning of bulky cover crop biomass, as practiced by some resource-limited smallholder farmers, reduces fertility benefits and increases nutrient losses (Oikeh et al. 2008). 
Cover cropping: long-term effects and adoption

Contrary to our expectations, the published studies found no strong evidence that cover crop effects on $\mathrm{P}$ nutrition of the main crop increase with time after introduction into the cropping system. The few long-term studies available (Kuo et al. 2005; Abdollahi and Munkholm 2014; Mbuthia et al. 2015; Mukumbareza et al. 2015) did not report substantially better results regarding $\mathrm{P}$ benefit than short-term experiments over 1 or 2 years. This indicates that cover crop management and selection of appropriate species could be more important than time since adoption of cover cropping, although more long-term trials are warranted. However, all the aforementioned studies and more (Balota et al. 2014) reported increases in microbial biomass and enzymatic activity. Regarding P pools, cover crops increased mainly the $\mathrm{P}_{\text {org }}$ and $\mathrm{P}_{\text {mic }}$ pools over time (Maltais-Landry et al. 2015; Mukumbareza et al. 2015) which may have been related to overall increases in SOM (Blanco-Canqui et al. 2015). Another study found no changes in soil $\mathrm{P}$ fractions after 9 years of cover cropping in a temperate system with high $\mathrm{P}$ availability (Kuo et al. 2005).

Cover cropping tends to provide better results in tropical than in temperate climates (data not shown). However, the numerous studies that show important main crop $\mathrm{P}$ benefits by cover cropping in temperate systems suggest that perhaps not only climate makes a difference, but also the prevailing agroecosystem. Studies in the tropics often involve low-P soils receiving fertilizer treatments, and are therefore more responsive to cover cropping compared to the northern countries whose mouldboardploughed fields are high in $\mathrm{P}_{\mathrm{a}}$. Additionally, given the management challenges of cover cropping, the greater experience with cover crops in the tropical regions may be an additional factor. However, except for regions with the limiting factors of water scarcity (as, e.g., in Mediterranean climates or with further climate change) and the short vegetation periods of cold areas, which strongly influence both plant growth and decomposition dynamics, cover cropping has the potential to be a successful management option in most climates.

Cover cropping is one of many agricultural tools and must be integrated and adapted adequately into the management strategy of an agroecosystem. Evaluation of both the multiple benefits and site-specific management needs of cover crops requires multi-faceted and whole-system approaches in research and extension
(Cherr et al. 2006). Cover crop species relevant for the local farming system for other reasons than $\mathrm{P}$ nutrition should also be tested. Economic benefits may be indirect, e.g., from the possibility of reduced planting densities after cover crops (Wang et al. 2008). An interdisciplinary or multidisciplinary approach involving farmers and other practitioners at early stages of experimental design may increase the efficiency and practical relevance of scientific studies (Weil and Kremen 2007; Reed 2008; Scopel et al. 2013; Smith et al. 2014).

Despite its many benefits, the use of cover cropping by farmers is often less utilized than is desirable. Barriers to adoption include the following: benefits are siteand soil-specific, establishment and management problems exist, and climatic variability can lead to uncertainty in outcome (Ro et al. 2016). Water use by the cover crop may be a problem under drought stress, resulting in lower yields and $\mathrm{P}$ uptake (Turmel et al. 2011). Economic considerations are necessary for adoption of a farming practice: in warmer climates there may be no off-season which means that cover crops compete directly with cash crops for the same space. To compensate for the income loss, the benefit over a continuous cropping system needs to be very high. Easilymanageable multi-purpose cover crops (edible seeds, fodder, wood) would be required to increase adoption by smallholder farmers in developing countries. Also, external factors, such as changes in land markets or novel pests, determine the adoption or abandonment of sustainable practices (Neill and Lee 2001). Reasons for low adoption of cover crops in temperate high-input systems are discussed by Brennan (2017).

The yield and $\mathrm{P}$ effects of cover crops hold across both organic and conventional cropping systems, as the results from five studies with 45 observations using organic fertilizers and no chemical weed control were not significantly different from the nine studies with 103 observations using conventional management practices (data not shown). In order to achieve widespread adoption of cover cropping, it is essential to overcome constraints to its adoption (e.g., insufficient experience for specific site conditions, unavailability of machinery, missing management alternatives in case of cover crop failure, and general pressure by markets to externalize costs). Improved management, increased knowledge, and development of instruments to relieve farmers of socially and environmentally unsustainable short-term market pressures, as for example community supported agriculture (CSA), are important (Lass et al. 2003). With rising fertilizer prices 


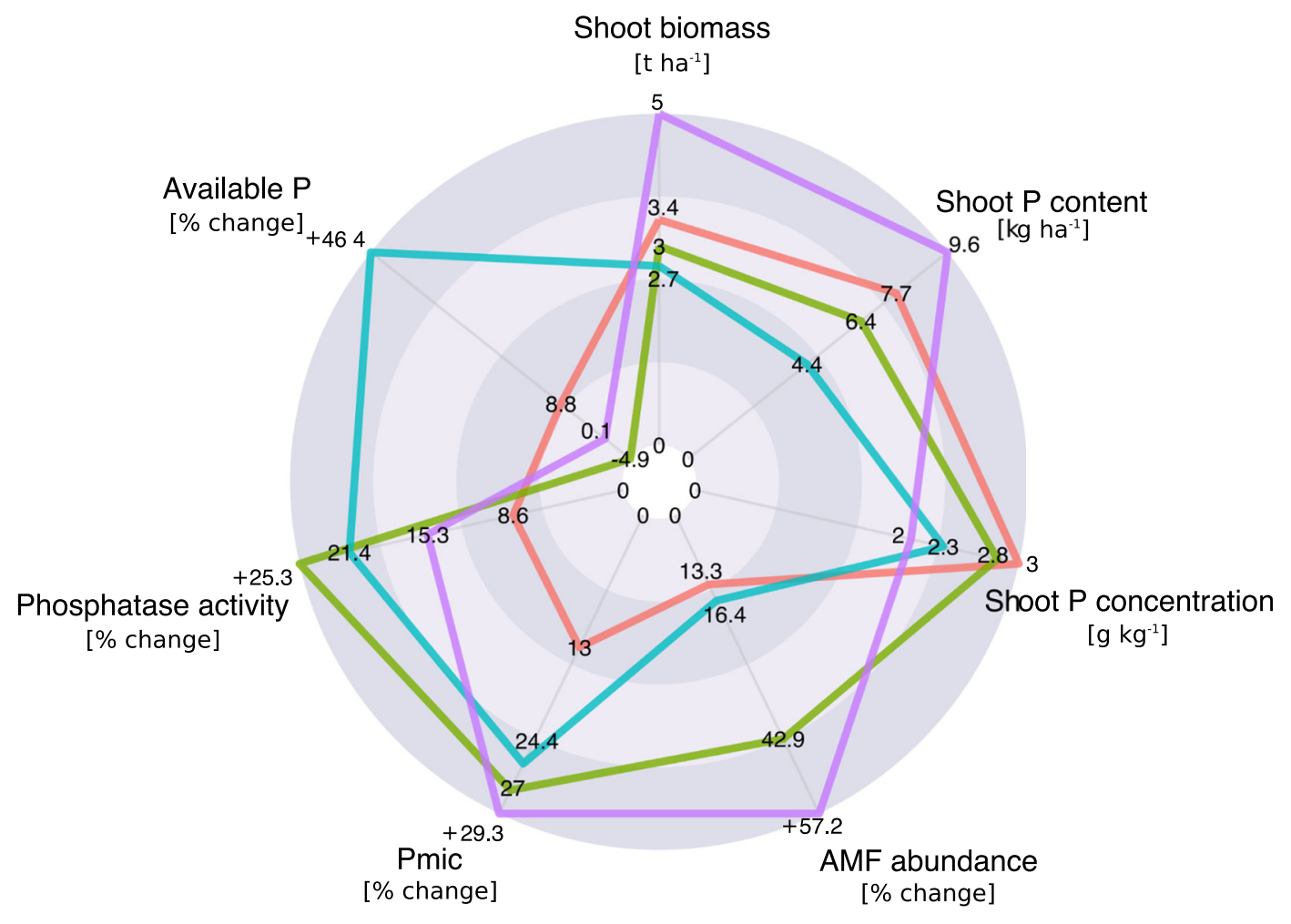

\section{- Brassicaceae - Fabaceae - Lupinus sp. - Poaceae}

Fig. 9 Radar chart summarizing the properties of the cover crop families and their effects on soil. The lines correspond to the calculated quantile moment of each data point ( $\mathrm{R}$ code provided

and pressure to reduce environmental impacts, cover crops constitute a promising, multifunctional tool for sustainable intensification of agriculture, on the conditions that species selection and management match the agricultural goals (Blanco-Canqui et al. 2015).

\section{Conclusions}

Cover crops can be successfully used to stimulate main crop yield and P uptake. However, site conditions and agronomic management lead to varying results. Plants have different $\mathrm{P}$-acquisition strategies, and main crops show varying abilities to take advantage of the cover crop legacy. Cover crops benefit the $\mathrm{P}$ nutrition of main crops by different, simultaneous processes: soil $\mathrm{P}$ (sometimes from sparingly-available pools) accumulates in the cover crop biomass, and the mineralization of P-rich litter provides available $\mathrm{P}$ for the main crop (plant-storage pathway). This pathway is most relevant for cover crops with high biomass such as Poaceae, in S4). Grid lines correspond to the $0,25,50,75$, and 100-quantiles of each variable. Asteraceae and Polygonaceae had missing data points and could not be displayed here.

Brassicaceae, and Fabaceae (Fig. 9). The P concentration of the cover crop biomass determines mineralization dynamics, which may partly explain the limited efficacy of Poaceae cover crops. Cover cropping enhances soil microbial community abundance $\left(\mathrm{P}_{\text {mic }}\right)$ and activity (extracellular phosphatase activity), and maize, in particular, benefits from increases in AMF abundance in soils with low available $\mathrm{P}$ (soil microbe pathway). Poaceae and Fabaceae have the greatest impact on soil microorganisms. Other cover crop species (e.g., Lupinus sp.) are capable of mining P pools, improving soil $\mathrm{P}$ availability even during the main crop phase (biochemical rhizosphere modification pathway).

Consideration of the abovementioned P-acquisition mechanisms, the interactions with the crop rotation, and the use of plant traits for the characterization of cover crop species would facilitate the generalization of the results of different studies. Further research is needed to elucidate the relative contributions of the different Pacquisition mechanisms, both to $\mathrm{P}$ uptake of the cover crop and their effects on the main crop, in order to 
optimize combinations. Soil $\mathrm{P}$ availability affects the $\mathrm{P}$ dynamics of the system and the mechanisms of cover crop benefit: generally, cover crops enhance main crop yield and $\mathrm{P}$ uptake in systems low in $\mathrm{P}_{\mathrm{a}}$ more than in systems with abundant $\mathrm{P}_{\mathrm{a}}$, and have a greater effect on abundance of AMF.

Cover crop benefits are greater with reduced tillage or no-till. Management determines the success of cover cropping in general, and it is possible to fine-tune $\mathrm{P}$ dynamics with appropriate techniques. Cover crops are used on a global scale under varying circumstances with successful examples in many regions and agroecosystems. However, cover crops may not be the optimal solution for $\mathrm{P}$ management in all situations. Factors that limit the use of cover crops, i.e. adverse climatic conditions (water scarcity, short growing seasons, freeze-thaw cycles), insufficient soil fertility, or problems with pests can be overcome by cover crop selection and management. However, for conventional high-input systems, though there is little likelihood of yield improvement, there is potential for environmental benefits.

Finally, in many areas of the world, the principal reason to include cover crops into the rotation is erosion control, which is probably the most important global issue regarding P management and soil in general. We need to avoid perpetuating systems in which single characteristics are overemphasized, resulting in significant trade-offs in overall performance and sustainability of agroecosystems. The isolated effect of a management practice (cover crop) on a single nutrient (P), may make sense in situations with one dominating limiting nutrient. Yet a more comprehensive evaluation of the ecosystem is required in most situations (Schipanski et al. 2014). This is especially the case for complex systems that replace technological inputs with ecosystem services of biological components. We need to find a balance that takes advantage of the numerous contributions of cover crops to agroecosystem health.

The effects of cover crops on $\mathrm{P}$ uptake of the main crop depend on many factors, offering opportunities for site-specific adoption and optimization of the system, but also restraining general agronomic recommendations. However, we can draw some broad conclusions about the potential for P management by cover-crop management and directions for future investigation:
- The different mechanisms of cover crop P benefit we have discussed, i.e. $\mathrm{P}$ transfer via cover crop residues, organic anion exudates, root-exuded enzymes, and microbial interactions, may happen simultaneously and warrant further investigation.

- Cover crop biomass determines in many cases the magnitude of its effect, because, in addition to the transfer of $\mathrm{P}$ in plant residues to the next crop, it affects the potential for rhizosphere modifications and microbial interactions. Appropriate management of the cover crop is required, acknowledging its importance to the overall return of the rotation. To determine suitable cover crop mixtures and management, more interdisciplinary projects are required.

- In order to advance our understanding of covercrop-related effects, we suggest for future research that comparability among studies through the inclusion of appropriate controls and additional data be improved, i.e. biomass and $\mathrm{P}$ content of cover crops and main crops, as well as soil biological parameters and soil $\mathrm{P}$ pools.

Bearing these suggestions in mind, scientists will be able to join farmers in moving towards soil improving cropping systems, through relevant research on the benefits of cover cropping.

Acknowledgements Hans-Peter Piepho and Fillippo Cappezzone from the Department of Biostatistics of the University of Hohenheim provided advice on the model structure. Sven Marhan and Christian Poll gave valuable comments on an earlier version of the manuscript. Aran Berihuete Hallama kindly produced the drawings. Moritz Hallama received funding from the European Union's Horizon 2020 research and innovation program under grant agreement No 677407 (SoilCare project).

Open Access This article is distributed under the terms of the Creative Commons Attribution 4.0 International License (http:// creativecommons.org/licenses/by/4.0/), which permits unrestricted use, distribution, and reproduction in any medium, provided you give appropriate credit to the original author(s) and the source, provide a link to the Creative Commons license, and indicate if changes were made.

\section{References}

Abdollahi L, Munkholm LJ (2014) Tillage system and cover crop effects on soil quality: I. chemical, mechanical, and biological properties. Soil Sci Soc Am J 78:262-270. https://doi. org/10.2136/sssaj2013.07.0301 
Almeida DS, Rosolem CA (2016) Ruzigrass grown in rotation with soybean increases soil labile phosphorus. Agron J 108: 2444-2452. https://doi.org/10.2134/agronj2015.0478

Altieri MA (2002) Agroecology: the science of natural resource management for poor farmers in marginal environments. Agric Ecosyst Environ 93:1-24. https://doi.org/10.1016 /S0167-8809(02)00085-3

Alvarez R, Steinbach HS, De Paepe JL (2017) Cover crop effects on soils and subsequent crops in the pampas: A meta-analysis. Soil Tillage Res 170:53-65. https://doi.org/10.1016/j. still.2017.03.005

Anugroho F, Kitou M, Nagumo F et al (2009) Growth, nitrogen fixation, and nutrient uptake of hairy vetch as a cover crop in a subtropical region. Weed Biol Manag 9:63-71. https://doi. org/10.1111/j.1445-6664.2008.00319.x

Arcand MM, Lynch DH, Voroney RP, van Straaten P (2010) Residues from a buckwheat (Fagopyrum esculentum) green manure crop grown with phosphate rock influence bioavailability of soil phosphorus. Can J Soil Sci 90:257-266. https://doi.org/10.4141/CJSS09023

Aristarán M, Tigas M, Jeremy B, Merrill JD (2017) Tabula: Extract tables from pdfs. https://tabula.technology/. Accessed 23 April 2018

Aronsson H, Hansen EM, Thomsen IK et al (2016) The ability of cover crops to reduce nitrogen and phosphorus losses from arable land in southern Scandinavia and Finland. J Soil Water Conserv 71:41-55. https://doi.org/10.2489/jswc.71.1.41

Azeem M, Riaz A, Chaudhary AN et al (2015) Microbial phytase activity and their role in organic P mineralization. Arch Agron Soil Sci 61:751-766. https://doi.org/10.1080 /03650340.2014.963796

Bachmann S, Eichler-Löbermann B (2010) Soil phosphorus pools as affected by application of poultry litter ash in combination with catch crop cultivation. Commun Soil Sci Plant Anal 41: 1098-1111. https://doi.org/10.1080/00103621003687182

Bagayoko M, Buerkert A, Lung G et al (2000) Cereal/legume rotation effects on cereal growth in Sudano-Sahelian West Africa: soil mineral nitrogen, mycorrhizae and nematodes. Plant Soil 218: 103-116. https://doi.org/10.1023/A:1014957605852

Bah AR, Zaharah AR, Hussin A (2006) Phosphorus uptake from green manures and phosphate fertilizers applied in an acid tropical soil. Commun Soil Sci Plant Anal 37:2077-2093. https://doi.org/10.1080/00103620600770433

Balota EL, Calegari A, Nakatani AS, Coyne MS (2014) Benefits of winter cover crops and no-tillage for microbial parameters in a Brazilian Oxisol: A long-term study. Agric Ecosyst Environ 197:31-40. https://doi.org/10.1016/j.agee.2014.07.010

Barber SA (1995) Soil nutrient bioavailability: A mechanistic approach. John Wiley \& Sons, New York

Barrett-Lennard EG, Dracup M, Greenway H (1993) Role of extracellular phosphatases in the phosphorus-nutrition of clover. J Exp Bot 44:1595-1600. https://doi.org/10.1093 /jxb/44.10.1595

Bashan Y, Kamnev AA, de-Bashan LE (2013) Tricalcium phosphate is inappropriate as a universal selection factor for isolating and testing phosphate-solubilizing bacteria that enhance plant growth: a proposal for an alternative procedure. Biol Fertil Soils 49:465-479. https://doi.org/10.1007 /s00374-012-0737-7
Bates D, Mächler M, Bolker B, Walker S (2015) Fitting linear mixed-effects models using lme4. J Stat Softw 67:1-48. https://doi.org/10.18637/jss.v067.i01

Bending GD, Aspray TJ, Whipps JM (2006) Significance of microbial interactions in the mycorrhizosphere. Adv Appl Microbiol 60:97-132. https://doi.org/10.1016/S0065-2164 (06)60004-X

Benitez M-S, Taheri WI, Lehman RM (2016) Selection of fungi by candidate cover crops. Appl Soil Ecol 103:72-82. https://doi. org/10.1016/j.apsoil.2016.03.016

Bergström L, Kirchmann H, Djodjic F et al (2015) Turnover and Losses of Phosphorus in Swedish Agricultural Soils: LongTerm Changes, Leaching Trends, and Mitigation Measures. J Environ Qual 44:512-523. https://doi.org/10.2134 /jeq2014.04.0165

Bernoux M, Cerri CC, Cerri CEP et al (2006) Cropping systems, carbon sequestration and erosion in Brazil, a review. Agron Sustain Dev 26:1-8. https://doi.org/10.1051/agro:2005055

Bittman S, Kowalenko CG, Hunt DE et al (2006) Starter phosphorus and broadcast nutrients on corn with contrasting colonization by Mycorrhizae. Agron J 98:394-401. https://doi.org/10.2134/agronj2005.0093

Blanchart E, Villenave C, Viallatoux A et al (2006) Long-term effect of a legume cover crop (Mucuna pruriens var. utilis) on the communities of soil macrofauna and nematofauna, under maize cultivation, in southern Benin. Eur J Soil Biol 42: S136-S144. https://doi.org/10.1016/j.ejsobi.2006.07.018

Blanco-Canqui H, Shaver TM, Lindquist JL et al (2015) Cover crops and ecosystem services: insights from studies in temperate soils. Agron J 107:2449-2474. https://doi.org/10.2134 /agronj15.0086

Boglaienko D, Soti P, Shetty KG, Jayachandran K (2014) Buckwheat as a cover crop in Florida: Mycorrhizal status and soil analysis. Agroecol Sustain Food Syst 38:1033-1046. https://doi.org/10.1080/21683565.2014.906016

Bommarco R, Kleijn D, Potts SG (2013) Ecological intensification: harnessing ecosystem services for food security. Trends Ecol Evol 28:230-238. https://doi.org/10.1016/j. tree.2012.10.012

Borie F, Zunino H (1983) Organic matter-phosphorus associations as a sink in P-fixation processes in allophanic soils of Chile. Soil Biol Biochem 15:599-603

Boswell EP, Koide RT, Shumway DL, Addy HD (1998) Winter wheat cover cropping, VA mycorrhizal fungi and maize growth and yield. Agric Ecosyst Environ 67:55-65. https://doi.org/10.1016/S0167-8809(97)00094-7

Bray RH, Kurtz LT (1945) Determination of total, organic, and available forms of phosphorus in soils. Soil Sci 59:39-46

Brennan EB (2017) Can we grow organic or conventional vegetables sustainably without cover crops? HortTechnology 27: 151-161. https://doi.org/10.21273/HORTTECH03358-16

Brennan EB, Acosta-Martinez V (2017) Cover cropping frequency is the main driver of soil microbial changes during six years of organic vegetable production. Soil Biol Biochem 109:188-204. https://doi.org/10.1016/j.soilbio.2017.01.014

Brennan EB, Boyd NS, Smith RF, Foster P (2009) Seeding rate and planting arrangement effects on growth and weed suppression of a legume-oat cover crop for organic vegetable systems. Agron J 101:979-988. https://doi.org/10.2134 /agronj2008.0194x 
Brophy LS, Heichel GH, Russelle MP (1987) Nitrogen transfer from forage legumes to grass in a systematic planting design. Crop Sci 27:753-758

Bünemann EK (2015) Assessment of gross and net mineralization rates of soil organic phosphorus-A review. Soil Biol Biochem 89:82-98

Bünemann EK, Bossio DA, Smithson PC et al (2004) Microbial community composition and substrate use in a highly weathered soil as affected by crop rotation and $\mathrm{P}$ fertilization. Soil Biol Biochem 36:889-901. https://doi.org/10.1016/j. soilbio.2004.02.002

Bünemann E, Oberson A, Frossard E (eds) (2011) Phosphorus in action: Biological processes in soil phosphorus cycling. Springer Berlin, Heidelberg

Buyer JS, Teasdale JR, Roberts DP et al (2010) Factors affecting soil microbial community structure in tomato cropping systems. Soil Biol Biochem 42:831-841. https://doi. org/10.1016/j.soilbio.2010.01.020

Calegari A, Tiecher T, Hargrove WL et al (2013) Long-term effect of different soil management systems and winter crops on soil acidity and vertical distribution of nutrients in a Brazilian Oxisol. Soil Tillage Res 133:32-39. https://doi.org/10.1016 /j.still.2013.05.009

Calonego JC, Rosolem CA (2010) Soybean root growth and yield in rotation with cover crops under chiseling and no-till. Eur $\mathrm{J}$ Agron 33:242-249. https://doi.org/10.1016/j. eja.2010.06.002

Cardoso DP, Silva MLN, De C et al (2013) Potential of cover plant species in reconditioning of physical and chemical properties of soil. Rev Bras Cienc Agrar 8:375-382. https://doi. org/10.5039/agraria.v8i3a2421

Carsky RJ, Oyewole B, Tian G (2001) Effect of phosphorus application in legume cover crop rotation on subsequent maize in the savanna zone of West Africa. Nutr Cycl Agroecosyst 59:151-159

Castillo-Caamal JB, Caamal-Maldonado JA (2011) Efecto de la fecha de siembra del frijol terciopelo (Mucuna sp.) como cultivo de cobertera en el rendimiento de maíz. Trop Subtrop Agroecosystems 14:101-108

Cavigelli MA, Thien SJ (2003) Phosphorus bioavailability following incorporation of green manure crops. Soil Sci Soc Am J 67:1186-1194

Cherr CM, Scholberg JMS, McSorley R (2006) Green manure approaches to crop production. Agron J 98:302-319. https://doi.org/10.2134/agronj2005.0035

Chien SH, Prochnow LI, Tu S, Snyder CS (2011) Agronomic and environmental aspects of phosphate fertilizers varying in source and solubility: an update review. Nutr Cycl Agroecosyst 89:229-255. https://doi.org/10.1007/s10705010-9390-4

Clark A (2008) Managing cover crops profitably, 3rd edn. DIANE Publishing, Darby

Clarkson DT (1985) Factors affecting mineral nutrient acquisition by plants. Annu Rev Plant Physiol 36:77-115

Cleveland CC, Liptzin D (2007) C:N:P stoichiometry in soil: is there a "Redfield ratio" for the microbial biomass? Biogeochemistry 85:235-252. https://doi.org/10.1007 /s10533-007-9132-0

Cole CV, Elliott ET, Hunt HW, Coleman DC (1977) Trophic interactions in soils as they affect energy and nutrient dynamics. V. Phosphorus transformations. Microb Ecol 4:381-387
Colwell JD (1963) The estimation of the phosphorus fertilizer requirements of wheat in southern New South Wales by soil analysis. Aust J Exp Agric 3:190-197. https://doi. org/10.1071/ea9630190

Condron LM, Frossard E, Tiessen H et al (1990) Chemical nature of organic phosphorus in cultivated and uncultivated soils under different environmental conditions. J Soil Sci 41:4150. https://doi.org/10.1111/j.1365-2389.1990.tb00043.x

Condron LM, Turner BL, Cade-Menun BJ (2005) Chemistry and dynamics of soil organic phosphorus. In: Sims JT, Sharpley AN (eds) Phosphorus: agriculture and the environment. American Society of Agronomy, Crop Science Society of America, Soil Science Society of America, Madison

Cordell D, White S (2014) Life's bottleneck: Sustaining the world's phosphorus for a food secure future. Annu Rev Environ Resour 39:161-188. https://doi.org/10.1146 /annurev-environ-010213-113300

Costa SEVGA, Souza ED, Anghinoni I et al (2014) Impact of an integrated no-till crop-livestock system on phosphorus distribution, availability and stock. Agric Ecosyst Environ 190: 43-51. https://doi.org/10.1016/j.agee.2013.12.001

Creamer NG, Dabney SM (2002) Killing cover crops mechanically: Review of recent literature and assessment of new research results. Am J Altern Agric 17:32-40

Cross AF, Schlesinger WH (1995) A literature review and evaluation of the Hedley fractionation: Applications to the biogeochemical cycle of soil phosphorus in natural ecosystems. Geoderma 64:197-214. https://doi.org/10.1016/0016-7061 (94)00023-4

Crossland M, Fradgley N, Creissen H et al (2015) An online toolbox for cover crops and living mulches. In: Aspects of Applied Biology. Association of Applied Biologists, Warwick, pp 1-6

$\mathrm{Cu}$ STT, Hutson J, Schuller KA (2005) Mixed culture of wheat (Triticum aestivum L.) with white lupin (Lupinus albus L.) improves the growth and phosphorus nutrition of the wheat. Plant Soil 272:143-151. https://doi.org/10.1007/s11104-0044336-8

Cui H, Zhou Y, Gu Z et al (2015) The combined effects of cover crops and symbiotic microbes on phosphatase gene and organic phosphorus hydrolysis in subtropical orchard soils. Soil Biol Biochem 82:119-126. https://doi.org/10.1016/j. soilbio.2015.01.003

Dabney SM, Delgado JA, Reeves DW (2001) Using winter cover crops to improve soil and water quality. Commun Soil Sci Plant Anal 32:1221-1250. https://doi.org/10.1081/CSS100104110

Dahlin AS, Stenberg M (2009) Cutting regime affects the amount and allocation of symbiotically fixed $\mathrm{N}$ in green manure leys. Plant Soil 331:401-412. https://doi.org/10.1007/s11104-0090261-1

Damon PM, Bowden B, Rose T, Rengel Z (2014) Crop residue contributions to phosphorus pools in agricultural soils: A review. Soil Biol Biochem 74:127-137. https://doi. org/10.1016/j.soilbio.2014.03.003

Damour G, Dorel M, Quoc HT et al (2014) A trait-based characterization of cover plants to assess their potential to provide a set of ecological services in banana cropping systems. Eur J Agron 52:218-228. https://doi.org/10.1016/j. eja.2013.09.004 
Dao TH, Schomberg HH, Cavigelli MA (2015) Tillage and rotational effects on exchangeable and enzyme-labile phosphorus forms in conventional and organic cropping systems. Nutr Cycl Agroecosyst 101:153-165. https://doi.org/10.1007 /s10705-014-9665-2

de Oliveira RA, Comin JJ, Tiecher T et al (2017) Release of phosphorus forms from cover crop residues in agroecological no-till onion production. Rev Bras Ciênc Solo 41:1-16. https://doi.org/10.1590/18069657rbcs20160272

Deguchi S, Shimazaki Y, Uozumi S et al (2007) White clover living mulch increases the yield of silage corn via arbuscular mycorrhizal fungus colonization. Plant Soil 291:291-299. https://doi.org/10.1007/s11104-007-9194-8

Deubel A, Gransee A, Merbach W (2000) Transformation of organic rhizodepositions by rhizosphere bacteria and its influence on the availability of tertiary calcium phosphate. J Plant Nutr Soil Sci 163:387-392. https://doi.org/10.1002/15222624(200008)163:4<387::AID-JPLN387>3.0.CO;2-K

Devi M, King S, Nivas D, Chandru S (2013) Enhancement of soil fertility through agro inputs on response to cover crop of crotalaria juncea L. In: Velu RK (ed) Microbiological Research in Agroecosystem Management. Springer, New Delhi, pp 175-186

Dinesh R, Suryanarayana MA, Ghoshal Chaudhuri S, Sheeja TE (2004) Long-term influence of leguminous cover crops on the biochemical properties of a sandy clay loam Fluventic Sulfaquent in a humid tropical region of India. Soil Tillage Res 77:69-77. https://doi.org/10.1016/j.still.2003.11.001

Dinkelaker B, Römheld V, Marschner H (1989) Citric acid excretion and precipitation of calcium citrate in the rhizosphere of white lupin (Lupinus albus L.). Plant Cell Environ 12:285-292

Ditterich F, Poll C, Pronk GJ et al (2016) Succession of soil microbial communities and enzyme activities in artificial soils. Pedobiologia 59:93-104. https://doi.org/10.1016/j. pedobi.2016.03.002

Dorado J, Zancada M-C, Almendros G, López-Fando C (2003) Changes in soil properties and humic substances after longterm amendments with manure and crop residues in dryland farming systems. J Plant Nutr Soil Sci 166:31-38. https://doi. org/10.1002/jpln.200390009

Dorn B, Stadler M, van der Heijden M, Streit B (2013) Regulation of cover crops and weeds using a roll-chopper for herbicide reduction in no-tillage winter wheat. Soil Tillage Res 134: 121-132. https://doi.org/10.1016/j.still.2013.07.014

Douds DD, Nagahashi G, Hepperly PR (2010) On-farm production of inoculum of indigenous arbuscular mycorrhizal fungi and assessment of diluents of compost for inoculum productions. Bioresour Technol 101:2326-2330. https://doi. org/10.1016/j.biortech.2009.11.071

Douds DD, Nagahashi G, Wilson DO, Moyer J (2011) Monitoring the decline in AM fungus populations and efficacy during a long term bare fallow. Plant Soil 342:319-326. https://doi. org/10.1007/s11104-010-0697-3

Dreymann S, Loges R, Taube F (2005) Schnittgutabfuhr oder Gründüngung? Auswirkung der Kleegras-Nutzung auf Nitrat im Sickerwasser und Folgefrüchte. In: Ende der Nische, Beiträge zur 8. Wissenschaftstagung Ökologischer Landbau

Dube E, Chiduza C, Muchaonyerwa P (2014) High biomass yielding winter cover crops can improve phosphorus availability in soil. South Afr J Sci 110:01-04. https://doi. org/10.1590/sajs.2014/20130135

Durán Zuazo VH, Rodríguez Pleguezuelo CR (2008) Soil-erosion and runoff prevention by plant covers. A review. Agron Sustain Dev 28:65-86. https://doi.org/10.1051/agro:2007062

Eichler-Löbermann B, Köhne S, Kowalski B, Schnug E (2008) Effect of catch cropping on phosphorus bioavailability in comparison to organic and inorganic fertilization. J Plant Nutr 31:659-676. https://doi.org/10.1080 /01904160801926517

Elfstrand S, Båth B, Mårtensson A (2007) Influence of various forms of green manure amendment on soil microbial community composition, enzyme activity and nutrient levels in leek. Appl Soil Ecol 36:70-82. https://doi.org/10.1016/j. apsoil.2006.11.001

Fageria NK, Gheyi HR, Carvalho MCS, Moreira A (2016) Root growth, nutrient uptake and use efficiency by roots of tropical legume cover crops as influenced by phosphorus fertilization. J Plant Nutr 39:781-792. https://doi.org/10.1080 /01904167.2015.1088020

Faucon M-P, Houben D, Reynoird J-P et al (2015) Advances and perspectives to improve the phosphorus availability in cropping systems for agroecological phosphorus management. In: Sparks DL (ed) Advances in Agronomy. Elsevier, New York, pp 51-79

Faucon M-P, Houben D, Lambers H (2017) Plant functional traits: Soil and ecosystem services. Trends Plant Sci 22:385-394. https://doi.org/10.1016/j.tplants.2017.01.005

Fester T, Sawers R (2011) Progress and challenges in agricultural applications of arbuscular mycorrhizal fungi. Crit Rev Plant Sci 30:459-470. https://doi.org/10.1080 /07352689.2011.605741

Franchini JC, Pavan MA, Miyazawa M (2004) Redistribution of phosphorus in soil through cover crop roots. Braz Arch Biol Technol 47:381-386. https://doi.org/10.1590/S151689132004000300007

Frey SD, Six J, Elliott ET (2003) Reciprocal transfer of carbon and nitrogen by decomposer fungi at the soil-litter interface. Soil Biol Biochem 35:1001-1004. https://doi.org/10.1016 /S0038-0717(03)00155-X

Frey-Klett P, Garbaye J, Tarkka M (2007) The mycorrhiza helper bacteria revisited. New Phytol 176:22-36. https://doi. org/10.1111/j.1469-8137.2007.02191.x

Furutani H, Marumaya H, Wasaki J, et al (2017) White lupin rootsecreted phosphatase and organic acids have a synergistic effect to mobilize unavailable phosphorus in soil. In: Proceedings of XVIII International Plant Nutrition Colloquium. University of Copenhagen, Copenhagen, pp 707-708

Gaind S, Nain L (2015) Soil-phosphorus mobilization potential of phytate mineralizing fungi. J Plant Nutr 38:2159-2175. https://doi.org/10.1080/01904167.2015.1014561

Galvez L, Douds DD, Wagoner P et al (1995) An overwintering cover crop increases inoculum of VAM fungi in agricultural soil. Am J Altern Agric 10:152-156. https://doi.org/10.1017 /S0889189300006391

Gardner WK, Boundy KA (1983) The acquisition of phosphorus by Lupinus albus L. IV. The effect of interplanting wheat and white lupin on the growth and mineral composition of the two species. Plant Soil 70:391-402 
Gardner WK, Barber DA, Parbery DG (1983) The acquisition of phosphorus by Lupinus albus L. Plant Soil 70:107-124. https://doi.org/10.1007/BF02374754

Garibay SV, Stamp P, Ammon HU, Feil B (1997) Yield and quality components of silage maize in killed and live cover crop sods. Eur J Agron 6:179-190. https://doi.org/10.1016 /S1161-0301(96)02043-6

Geleta SB, Briand CH, Womack HE et al (2006) Is phosphorus fertilization necessary for watermelon production on high phosphorus soils? Can J Plant Sci 86:205-211. https://doi. org/10.4141/P04-093

George TS, Giles CD, Menezes-Blackburn D et al (2018) Organic phosphorus in the terrestrial environment: a perspective on the state of the art and future priorities. Plant Soil 427:191208. https://doi.org/10.1007/s11104-017-3391-x

Gerke J, Meyer U (1995) Phosphate aquisition by red clover and black mustard on a humic Podzol. J Plant Nutr 18:24092429. https://doi.org/10.1080/01904169509365074

Giaveno C, Celi L, Richardson AE et al (2010) Interaction of phytases with minerals and availability of substrate affect the hydrolysis of inositol phosphates. Soil Biol Biochem 42:491-498. https://doi.org/10.1016/j.soilbio.2009.12.002

Gichangi EM, Njarui DMG, Gatheru MJ et al (2016) Effects of brachiaria grasses on soil microbial biomass carbon, nitrogen and phosphorus in soils of the semi arid tropics of Kenia. Trop Subtrop Agroecosystems 19:193-203

Giles CD, George TS, Brown LK et al (2017) Linking the depletion of rhizosphere phosphorus to the heterologous expression of a fungal phytase in Nicotiana tabacum as revealed by enzyme-labile $\mathrm{P}$ and solution 31P NMR spectroscopy. Rhizosphere 3:82-91. https://doi.org/10.1016/j. rhisph.2016.11.004

Giovannetti M, Turrini A, Strani P et al (2006) Mycorrhizal fungi in ecotoxicological studies: soil impact of fungicides, insecticides and herbicides. Prev Today 2:47-62

Groffman PM, Hendrix PF, Crossley DA (1987) Effects of a winter legume on phosphorus, potassium, calcium and magnesium cycling in a humid subtropical agroecosystem. Agric Ecosyst Environ 18:281-289. https://doi.org/10.1016/01678809(87)90095-8

Guo F, Yost RS, Hue NV et al (2000) Changes in phosphorus fractions in soils under intensive plant growth. Soil Sci Soc Am J 64:1681-1689

Guppy CN, Menzies NW, Moody PW, Blamey FPC (2005) Competitive sorption reactions between phosphorus and organic matter in soil: a review. Soil Res 43:189-202. https://doi.org/10.1071/SR04049

Haramoto ER, Gallandt ER (2004) Brassica cover cropping for weed management: A review. Renewable Agric Food Syst 19:187-198 https://doi.org/10.1079/RAFS200490

Harold FM (1966) Inorganic polyphosphates in biology: structure, metabolism, and function. Bacteriol Rev 30:772-794

Harrison AF (1987) Soil organic phosphorus: a review of world literature. $\mathrm{CAB}$ International, Wallingford

Hayat R, Ali S, Amara U et al (2010) Soil beneficial bacteria and their role in plant growth promotion: a review. Ann Microbiol 60:579-598. https://doi.org/10.1007/s13213-010-0117-1

Hedley MJ, Stewart JWB, Chauhan BS (1982) Changes in inorganic and organic soil phosphorus fractions induced by cultivation practices and by laboratory incubations. Soil Sci Soc Am J 46:970-976
Higo M, Isobe K, Drijber RA et al (2014) Impact of a 5-year winter cover crop rotational system on the molecular diversity of arbuscular mycorrhizal fungi colonizing roots of subsequent soybean. Biol Fertil Soils 50:913-926. https://doi. org/10.1007/s00374-014-0912-0

Hinsinger P (2001) Bioavailability of soil inorganic P in the rhizosphere as affected by root-induced chemical changes: a review. Plant Soil 237:173-195. https://doi.org/10.1023 /A:1013351617532

Hinsinger P, Bengough AG, Vetterlein D, Young IM (2009) Rhizosphere: biophysics, biogeochemistry and ecological relevance. Plant Soil 321:117-152. https://doi.org/10.1007 /s11104-008-9885-9

Hinsinger P, Brauman A, Devau N et al (2011) Acquisition of phosphorus and other poorly mobile nutrients by roots. Where do plant nutrition models fail? Plant Soil 348:29-61. https://doi.org/10.1007/s11104-011-0903-y

Hinsinger P, Herrmann L, Lesueur D et al (2015) Impact of roots, microorganisms and microfauna on the fate of soil phosphorus in the rhizosphere. In: Plaxton W, Lambers H (eds) Phosphorus Metabolism of Plants. John Wiley \& Sons, New York, pp 377-407

Hobbs PR, Sayre K, Gupta R (2008) The role of conservation agriculture in sustainable agriculture. Philos Trans R Soc B Biol Sci 363:543-555. https://doi.org/10.1098 /rstb.2007.2169

Hoffland E, Van Den Boogaard R, Nelemans J, Findenegg G (1992) Biosynthesis and root exudation of citric and malic acids in phosphate-starved rape plants. New Phytol 122:675680. https://doi.org/10.1111/j.1469-8137.1992.tb00096.x

Høgh-Jensen H, Schjørring JK (1997) Interactions between white clover and ryegrass under contrasting nitrogen availability: $\mathrm{N} 2$ fixation, $\mathrm{N}$ fertilizer recovery, $\mathrm{N}$ transfer and water use efficiency. Plant Soil 197:187-199

Horst WJ, Waschkies C (1987) Phosphatversorgung von Sommerweizen (Triticum aestivum L.) in Mischkultur mit Weißer Lupine (Lupinus albus L.). Z Für Pflanzenernähr Bodenkd 150:1-8. https://doi.org/10.1002/jpln.19871500102

Horst WJ, Kamh M, Jibrin JM, Chude VO (2001) Agronomic measures for increasing $\mathrm{P}$ availability to crops. Plant Soil 237:211-223

Hunter PJ, Teakle GR, Bending GD (2014) Root traits and microbial community interactions in relation to phosphorus availability and acquisition, with particular reference to Brassica. Front Plant Sci 5:1-18. https://doi.org/10.3389/fpls.2014.00027

Ikerra ST, Semu E, Mrema JP (2006) Combining Tithonia diversifolia and minjingu phosphate rock for improvement of $\mathrm{P}$ availability and maize grain yields on a chromic acrisol in Morogoro, Tanzania. Nutr Cycl Agroecosyst 76:249-260. https://doi.org/10.1007/s10705-006-9007-0

Janegitz MC, Inoue BS, Rosolem CA (2013) Soil phosphorus pools as affected by brachiaria and white lupin. Cienc Rural 43:1381-1386. https://doi.org/10.1590/S010384782013000800007

Jansa J, Finlay R, Wallander H et al (2011) Role of mycorrhizal symbioses in phosphorus cycling. In: Bünemann E, Oberson A, Frossard E (eds) Phosphorus in Action. Springer Berlin, Heidelberg, pp 137-168

Jemo M, Abaidoo RC, Nolte C et al (2006) Phosphorus benefits from grain-legume crops to subsequent maize grown on acid 
soils of southern Cameroon. Plant Soil 284:385-397. https://doi.org/10.1007/s11104-006-0052-x

Jensen LS, Pedersen A, Magid J, Nielsen NE (2005) Catch crops have little effect on $\mathrm{P}$ and $\mathrm{K}$ availability of depleted soils. DARCOF E-News 2:1-7

Johal GS, Huber DM (2009) Glyphosate effects on diseases of plants. Eur J Agron 31:144-152. https://doi.org/10.1016/j. eja.2009.04.004

Johnson NC, Graham JH, Smith FA (1997) Functioning of mycorrhizal associations along the mutualism-parasitism continuum. New Phytol 135:575-585

Joner EJ, Aarle IM van, Vosatka M (2000) Phosphatase activity of extra-radical arbuscular mycorrhizal hyphae: A review. Plant Soil 226:199-210

Jones DL (1998) Organic acids in the rhizosphere - a critical review. Plant Soil 205:25-44. https://doi.org/10.1023 /A: 1004356007312

Jones DL, Edwards AC (1998) Influence of sorption on the biological utilization of two simple carbon substrates. Soil Biol Biochem 30:1895-1902. https://doi.org/10.1016 /S0038-0717(98)00060-1

Jones DL, Oburger E (2011) Solubilization of phosphorus by soil microorganisms. In: Bünemann E, Oberson A, Frossard E (eds) Phosphorus in Action. Springer Berlin, Heidelberg, pp 169-198

Jorquera MA, Hernández MT, Rengel Z et al (2008) Isolation of culturable phosphobacteria with both phytate-mineralization and phosphate-solubilization activity from the rhizosphere of plants grown in a volcanic soil. Biol Fertil Soils 44:10251034. https://doi.org/10.1007/s00374-008-0288-0

Kabir Z, Koide RT (2000) The effect of dandelion or a cover crop on mycorrhiza inoculum potential, soil aggregation and yield of maize. Agric Ecosyst Environ 78:167-174. https://doi. org/10.1016/S0167-8809(99)00121-8

Kabir Z, Koide RT (2002) Effect of autumn and winter mycorrhizal cover crops on soil properties, nutrient uptake and yield of sweet corn in Pennsylvania, USA. Plant Soil 238:205-215

Kamh M, Horst WJ, Chude VO (1998) Mobilization of soil and fertilizer phosphate by cover crops. In: Merbach PDW (ed) Pflanzenernährung, Wurzelleistung und Exsudation. Vieweg+Teubner Verlag, Leipzig, pp 167-177

Kamh M, Abdou M, Chude V et al (2002) Mobilization of phosphorus contributes to positive rotational effects of leguminous cover crops on maize grown on soils from northern Nigeria. J Plant Nutr Soil Sci 165:566-572. https://doi. org/10.1002/1522-2624(200210)165:5<566::AID-JPLN566 $>3.0 . \mathrm{CO} ; 2-\mathrm{O}$

Karasawa T, Takahashi S (2015) Introduction of various cover crop species to improve soil biological $\mathrm{P}$ parameters and $\mathrm{P}$ uptake of the following crops. Nutr Cycl Agroecosyst 103: 15-28. https://doi.org/10.1007/s10705-015-9715-4

Karasawa T, Takebe M (2012) Temporal or spatial arrangements of cover crops to promote arbuscular mycorrhizal colonization and $\mathrm{P}$ uptake of upland crops grown after nonmycorrhizal crops. Plant Soil 353:355-366. https://doi. org/10.1007/s11104-011-1036-Z

Kelly JB, Midgley AR (1943) Phosphate fixation -An exchange of phosphate and hydroxyl ions. Soil Sci 55:167-176

Kirchmann H, Wessling J (2017) Kinetics of inorganic and organic $P$ release from red clover (Trifolium pratense L.) and ryegrass ( Lolium multiflorum L.) upon frost or drying. Acta
Agric Scand Sect B - Soil Plant Sci 67:693-696. https://doi. org/10.1080/09064710.2017.1339823

Kleinman PJ, Salon P, Sharpley AN (2001) Evaluating alternative cover crops for the control of runoff phosphorus losses. In: 2001 Annual meetings abstracts. ASA, CSSA, and SSSA, Madison

Koide RT, Mosse B (2004) A history of research on arbuscular mycorrhiza. Mycorrhiza 14:145-163. https://doi.org/10.1007 /s00572-004-0307-4

Koné AW, Tondoh JE, Angui PKT et al (2008) Is soil quality improvement by legume cover crops a function of the initial soil chemical characteristics? Nutr Cycl Agroecosyst 82:89 105. https://doi.org/10.1007/s10705-008-9172-4

Kunze A, Costa MD, Epping J et al (2011) Phosphatase activity in sandy soil influenced by mycorrhizal and non-mycorrhizal cover crops. Rev Bras Ciênc Solo 35:705-711. https://doi. org/10.1590/S0100-06832011000300005

Kuo S, Huang B, Bembenek R (2005) Effects of long-term phosphorus fertilization and winter cover cropping on soil phosphorus transformations in less weathered soil. Biol Fertil Soils 41:116-123. https://doi.org/10.1007/s00374-004-0807-6

Kuznetsova A, Brockhoff P, Christensen R (2017) lmerTest Package: Tests in Linear Mixed Effects Models. J Stat Softw Articles 82:1-26. https://doi.org/10.18637/jss.v082. i13

Lal R, Wilson GF, Okigbo BN (1978) No-till farming after various grasses and leguminous cover crops in tropical Alfisol. I. Crop performance. Field Crop Res 1:71-84

Lambers H, Teste FP (2013) Interactions between arbuscular mycorrhizal and non-mycorrhizal plants: do nonmycorrhizal species at both extremes of nutrient availability play the same game? Plant Cell Environ 36:1911-1915. https://doi.org/10.1111/pce.12117

Lambers H, Shane MW, Cramer MD et al (2006) Root structure and functioning for efficient acquisition of phosphorus: matching morphological and physiological traits. Ann Bot 98:693-713. https://doi.org/10.1093/aob/mcl114

Lambers H, Clements JC, Nelson MN (2013) How a phosphorusacquisition strategy based on carboxylate exudation powers the success and agronomic potential of lupines (Lupinus, Fabaceae). Am J Bot 100:263-288. https://doi.org/10.3732 lajb.1200474

Lambers H, Clode PL, Hawkins H-J et al (2015a) Metabolic adaptations of the non-mycotrophic Proteaceae to soils with low phosphorus availability. In: Plaxton WC, Lambers $\mathrm{H}$ (eds) Phosphorus Metabolism in Plants. John Wiley \& Sons, Inc., Hoboken, pp 289-335

Lambers H, Hayes PE, Laliberté E et al (2015b) Leaf manganese accumulation and phosphorus-acquisition efficiency. Trends Plant Sci 20:83-90. https://doi.org/10.1016/j. tplants.2014.10.007

Lambers H, Albornoz F, Kotula L et al (2018) How belowground interactions contribute to the coexistence of mycorrhizal and non-mycorrhizal species in severely phosphorusimpoverished hyperdiverse ecosystems. Plant Soil 424:1133. https://doi.org/10.1007/s11104-017-3427-2

Lang F, Krüger J, Amelung W et al (2017) Soil phosphorus supply controls P nutrition strategies of beech forest ecosystems in Central Europe. Biogeochemistry 136:5-29. https://doi. org/10.1007/s10533-017-0375-0 
Lass D, Bevis A, Stevenson GW et al (2003) Community supported agriculture entering the 21st century: Results from the 2001 national survey. University of Massachusetts, Amherst

Lehman RM, Taheri WI, Osborne SL et al (2012) Fall cover cropping can increase arbuscular mycorrhizae in soils supporting intensive agricultural production. Appl Soil Ecol 61:300-304. https://doi.org/10.1016/j.apsoil.2011.11.008

LeMare P, Pereira J, Goedert W (1987) Effects of green manure on isotopically exchangeable phosphate in a dark-red latosol in Brazil. J Soil Sci 38:199-209

Lenth R (2018) emmeans: Estimated marginal means, aka leastsquares means, R package Version 1.1, https://CRAN.Rproject.org/package=emmeans. Accessed 21 Jan 2018

Li L, Li S-M, Sun J-H et al (2007) Diversity enhances agricultural productivity via rhizosphere phosphorus facilitation on phosphorus-deficient soils. Proc Natl Acad Sci 104:1119211196. https://doi.org/10.1073/pnas.0704591104

Li L, Tilman D, Lambers H, Zhang F-S (2014) Plant diversity and overyielding: insights from belowground facilitation of intercropping in agriculture. New Phytol 203:63-69. https://doi.org/10.1111/nph.12778

Li B, Li Y-Y, Wu H-M et al (2016) Root exudates drive interspecific facilitation by enhancing nodulation and N2 fixation. Proc Natl Acad Sci 113:6496-6501. https://doi.org/10.1073 /pnas. 1523580113

Little SA, Hocking PJ, Greene RSB (2004) A preliminary study of the role of cover crops in improving soil fertility and yield for potato production. Commun Soil Sci Plant Anal 35:471-494. https://doi.org/10.1081/CSS-120029726

Liu J, Bergkvist G, Ulén B (2015) Biomass production and phosphorus retention by catch crops on clayey soils in southern and central Sweden. Field Crop Res 171:130-137. https://doi.org/10.1016/j.fcr.2014.11.013

Lüdecke D (2018) sjPlot: Data Visualization for Statistics in Social Science, R package version 2.6.0.9000. https://CRAN.Rproject.org/package=sjPlot. Accessed 21 Jan 2018

Ma X-F, Wright E, Ge Y et al (2009) Improving phosphorus acquisition of white clover (Trifolium repens L.) by transgenic expression of plant-derived phytase and acid phosphatase genes. Plant Sci 176:479-488. https://doi.org/10.1016/j. plantsci.2009.01.001

Maltais-Landry G (2015) Legumes have a greater effect on rhizosphere properties ( $\mathrm{pH}$, organic acids and enzyme activity) but a smaller impact on soil $\mathrm{P}$ compared to other cover crops. Plant Soil 394:139-154. https://doi.org/10.1007/s11104-0152518-1

Maltais-Landry G, Frossard E (2015) Similar phosphorus transfer from cover crop residues and water-soluble mineral fertilizer to soils and a subsequent crop. Plant Soil 393:193-205. https://doi.org/10.1007/s11104-015-2477-6

Maltais-Landry G, Scow K, Brennan E, Vitousek P (2015) Longterm effects of compost and cover crops on soil phosphorus in two California agroecosystems. Soil Sci Soc Am J 79:688697. https://doi.org/10.2136/sssaj2014.09.0369

Mamy L, Barriuso E, Gabrielle B (2016) Glyphosate fate in soils when arriving in plant residues. Chemosphere 154:425-433. https://doi.org/10.1016/j.chemosphere.2016.03.104

Marilley L, Aragno M (1999) Phylogenetic diversity of bacterial communities differing in degree of proximity of Lolium perenne and Trifolium repens roots. Appl Soil Ecol 13:127136. https://doi.org/10.1016/S0929-1393(99)00028-1
Marschner P, Yang C-H, Lieberei R, Crowley DE (2001) Soil and plant specific effects on bacterial community composition in the rhizosphere. Soil Biol Biochem 33:1437-1445. https://doi.org/10.1016/S0038-0717(01)00052-9

Mason SD, McLaughlin MJ, Johnston C, McNeill A (2013) Soil test measures of available P (Colwell, resin and DGT) compared with plant $\mathrm{P}$ uptake using isotope dilution. Plant Soil 373:711-722. https://doi.org/10.1007/s11104-013-1833-7

Mat Hassan H, Hasbullah H, Marschner P (2013) Growth and rhizosphere $\mathrm{P}$ pools of legume-wheat rotations at low $\mathrm{P}$ supply. Biol Fertil Soils 49:41-49. https://doi.org/10.1007 /s00374-012-0695-0

Mbuthia LW, Acosta-Martínez V, DeBruyn J et al (2015) Long term tillage, cover crop, and fertilization effects on microbial community structure, activity: Implications for soil quality. Soil Biol Biochem 89:24-34. https://doi.org/10.1016/j. soilbio.2015.06.016

McLaren TI, Smernik RJ, McLaughlin MJ et al (2015) Complex forms of soil organic phosphorus-A major component of soil phosphorus. Environ Sci Technol 49:13238-13245. https://doi.org/10.1021/acs.est.5b02948

McLaughlin MJ, McBeath TM, Smernik R et al (2011) The chemical nature of $\mathrm{P}$ accumulation in agricultural soilsimplications for fertiliser management and design: an Australian perspective. Plant Soil 349:69-87. https://doi. org/10.1007/s11104-011-0907-7

Medhi DN, Datta SKD (1996) Phosphorus availability to irrigated lowland rice as affected by sources, application level and green manure. Nutr Cycl Agroecosyst 46:195-203. https://doi.org/10.1007/BF00420554

Mehlich A (1984) Mehlich 3 soil test extractant: A modification of Mehlich 2 extractant. Commun Soil Sci Plant Anal 15:14091416. https://doi.org/10.1080/00103628409367568

Menezes-Blackburn D, Jorquera MA, Greiner R et al (2012) Phytases and phytase-labile organic phosphorus in manures and soils. Crit Rev Environ Sci Technol 43:916-954. https://oi.org/10.1080/10643389.2011.627019

Menezes-Blackburn D, Giles C, Darch T et al (2018) Opportunities for mobilizing recalcitrant phosphorus from agricultural soils: a review. Plant Soil 427:5-16. https://doi. org/10.1007/s11104-017-3362-2

Messiga AJ, Sharifi M, Munroe S (2016) Combinations of cover crop mixtures and bio-waste composts enhance biomass production and nutrients accumulation: a greenhouse study. Renew Agric Food Syst 31:507-515. https://doi.org/10.1017 /S1742170515000423

Miguez FE, Bollero GA (2005) Review of corn yield response under winter cover cropping systems using meta-analytic methods. Crop Sci 45:2318-2329. https://doi.org/10.2135 /cropsci2005.0014

Mirsky SB, Ryan MR, Curran WS et al (2012) Conservation tillage issues: Cover crop-based organic rotational no-till grain production in the mid-Atlantic region, USA. Renew Agric Food Syst 27:31-40. https://doi.org/10.1017 /S1742170511000457

Moonen AC, Bàrberi P (2006) An ecological approach to study the physical and chemical effects of rye cover crop residues on Amaranthus retroflexus, Echinochloa crus-galli and maize. Ann Appl Biol 148:73-89. https://doi.org/10.1111 j.1744-7348.2006.00038.x 
Mukumbareza C, Muchaonyerwa P, Chiduza C (2015) Effects of oats and grazing vetch cover crops and fertilisation on microbial biomass and activity after five years of rotation with maize. South Afr J Plant Soil 32:189-197. https://doi. org/10.1080/02571862.2015.1025446

Murphy J, Riley JP (1962) A modified single solution method for the determination of phosphate in natural waters. Anal Chim Acta $27: 31-36$

Murungu FS, Chiduza C, Muchaonyerwa P, Mnkeni PNS (2011a) Decomposition, nitrogen and phosphorus mineralization from winter-grown cover crop residues and suitability for a smallholder farming system in South Africa. Nutr Cycl Agroecosyst 89:115-123. https://doi.org/10.1007/s10705010-9381-5

Murungu FS, Chiduza C, Muchaonyerwa P, Mnkeni PNS (2011b) Mulch effects on soil moisture and nitrogen, weed growth and irrigated maize productivity in a warm-temperate climate of South Africa. Soil Tillage Res 112:58-65. https://doi. org/10.1016/j.still.2010.11.005

Muzangwa L, Chiduza C, Muchaonyerwa P (2012) Biomass production, weed suppression, nitrogen and phosphorus uptake in white oat (Avena sativa L.) and grazing vetch (Vicia dasycarpa L.) cover crop bicultures under an irrigated no-till system. S Afr J Plant Soil 29:135-141. https://doi. org/10.1080/02571862.2012.741719

Nannipieri P, Ascher J, Ceccherini MT et al (2008) Effects of root exudates in microbial diversity and activity in rhizosphere soils. In: Nautiyal PDCS, Dion PDP (eds) Molecular mechanisms of plant and microbe coexistence. Springer Berlin, Heidelberg, pp 339-365

Nannipieri P, Giagnoni L, Landi L, Renella G (2011) Role of phosphatase enzymes in soil. In: Bünemann E, Oberson A, Frossard E (eds) Phosphorus in Action. Springer Berlin, Heidelberg, pp 215-243

Nascente AS, Crusciol CAC, Cobucci T, Velini ED (2013) Cover crop termination timing on rice crop production in a no-till system. Crop Sci 53:2659-2669. https://doi.org/10.2135 /cropsci2013.01.0047

Negassa W, Leinweber P (2009) How does the Hedley sequential phosphorus fractionation reflect impacts of land use and management on soil phosphorus: A review. J Plant Nutr Soil Sci 172:305-325. https://doi.org/10.1002 /jpln.200800223

Neill SP, Lee DR (2001) Explaining the adoption and disadoption of sustainable agriculture: the case of cover crops in northern Honduras. Econ Dev Cult Chang 49:793-820

Newman EI, Eason WR (1989) Cycling of nutrients from dying roots to living plants, including the role of mycorrhizas. Plant Soil 115:211-215

Njeru EM, Avio L, Sbrana C et al (2014) First evidence for a major cover crop effect on arbuscular mycorrhizal fungi and organic maize growth. Agron Sustain Dev 34:841-848. https://doi. org/10.1007/s13593-013-0197-y

Nuruzzaman M, Lambers H, Bolland MD, Veneklaas EJ (2005a) Phosphorus uptake by grain legumes and subsequently grown wheat at different levels of residual phosphorus fertiliser. Crop Pasture Sci 56:1041-1047

Nuruzzaman M, Lambers H, Bolland MD, Veneklaas EJ (2005b) Phosphorus benefits of different legume crops to subsequent wheat grown in different soils of Western Australia. Plant Soil 271:175-187. https://doi.org/10.1007/s11104-004-2386-6
Nuruzzaman M, Lambers H, Bolland MDA, Veneklaas EJ (2006) Distribution of carboxylates and acid phosphatase and depletion of different phosphorus fractions in the rhizosphere of a cereal and three grain legumes. Plant Soil 281:109-120. https://doi.org/10.1007/s11104-005-3936-2

Oberson A, Bünemann E, Friesen DK et al (2006) Improving Phosphorus Fertility in Tropical Soils through Biological Interventions. In: Uphoff N (ed) Biological Approaches to Sustainable Soil Systems. CRC Press, Boca Raton, pp 531546

Oburger E, Jones DL, Wenzel WW (2011) Phosphorus saturation and $\mathrm{pH}$ differentially regulate the efficiency of organic acid anion-mediated P solubilization mechanisms in soil. Plant Soil 341:363-382. https://doi.org/10.1007/s11104-0100650-5

Odhiambo JJO, Bomke AA (2007) Cover crop effects on spring soil water content and the implications for cover crop management in south coastal British Columbia. Agric Water Manag 88:92-98. https://doi.org/10.1016/j. agwat.2006.09.001

Oehl F, Oberson A, Probst M et al (2001) Kinetics of microbial phosphorus uptake in cultivated soils. Biol Fertil Soils 34: 31-41. https://doi.org/10.1007/s003740100362

Oehl F, Sieverding E, Ineichen K et al (2003) Impact of Land Use Intensity on the Species Diversity of Arbuscular Mycorrhizal Fungi in Agroecosystems of Central Europe. Appl Environ Microbiol 69:2816-2824. https://doi.org/10.1128 /AEM.69.5.2816-2824.2003

Ohno T, Crannell BS (1996) Green and animal manure-derived dissolved organic matter effects on phosphorus sorption. J Environ Qual 25:1137-1143. https://doi.org/10.2134 /jeq1996.00472425002500050029x

Oikeh SO, Somado EA, Sahrawat KL et al (2008) Rice yields enhanced through integrated management of cover crops and phosphate rock in phosphorus-deficient Ultisols in West Africa. Commun Soil Sci Plant Anal 39:2894-2919. https://doi.org/10.1080/00103620802432816

Olsen SR, Cole CV, Watanabe FS, Dean LA (1954) Estimation of available phosphorus in soils by extraction with sodium bicarbonate. Circ U S Dep Agric 939:1-18

Opala PA, Okalebo JR, Othieno CO, Kisinyo P (2010) Effect of organic and inorganic phosphorus sources on maize yields in an acid soil in western Kenya. Nutr Cycl Agroecosyst 86: 317-329. https://doi.org/10.1007/s10705-009-9294-3

Pang J, Ruchi B, Zhao H et al (2018a) The carboxylate-releasing phosphorus-mobilising strategy can be proxied by foliar manganese concentration in a large set of chickpea germplasm under low phosphorus supply. New Phytol 219:518-529

Pang J, Zhao H, Bansal R, et al (2018b) Leaf transpiration plays a role in phosphorus acquisition among a large set of chickpea genotypes. Plant Cell Environ 1-11. https://doi.org/10.1111 /pce.13139

Parihar CM, Jat SL, Singh AK et al (2016) Conservation agriculture in irrigated intensive maize-based systems of northwestern India: Effects on crop yields, water productivity and economic profitability. Field Crop Res 193:104-116. https://doi.org/10.1016/j.fcr.2016.03.013

Parray JA, Jan S, Kamili AN et al (2016) Current perspectives on plant growth-promoting rhizobacteria. J Plant Growth Regul 35:877-902. https://doi.org/10.1007/s00344-016-9583-4 
Pavinato PS, Rodrigues M, Soltangheisi A et al (2017) Effects of cover crops and phosphorus sources on maize yield, phosphorus uptake, and phosphorus use efficiency. Agron J 109: 1-9. https://doi.org/10.2134/agronj2016.06.0323

Pearse SJ, Veneklaas EJ, Cawthray G et al (2006) Triticum aestivum shows a greater biomass response to a supply of aluminium phosphate than Lupinus albus, despite releasing fewer carboxylates into the rhizosphere. New Phytol 169: 515-524. https://doi.org/10.1111/j.1469-8137.2005.01614.x

Philippot L, Bru D, Saby NPA et al (2009) Spatial patterns of bacterial taxa in nature reflect ecological traits of deep branches of the 16S rRNA bacterial tree. Environ Microbiol 11:3096-3104. https://doi.org/10.1111/j.14622920.2009.02014.x

Pierre W, Parker F (1927) Soil phosphorus studies: II. The concentration of organic and inorganic phosphorus in the soil solution and soil extracts and the availability of organic phosphorus of plants. Soil Sci 24:119-128

Plenchette C, Clermont-Dauphin C, Meynard JM, Fortin JA (2005) Managing arbuscular mycorrhizal fungi in cropping systems. Can J Plant Sci 85:31-40

Poeplau C, Don A (2015) Carbon sequestration in agricultural soils via cultivation of cover crops - A meta-analysis. Agric Ecosyst Environ 200:33-41. https://doi.org/10.1016/j. agee.2014.10.024

Possinger AR, Byrne LB, Breen NE (2013) Effect of buckwheat (Fagopyrum esculentum) on soil-phosphorus availability and organic acids. J Plant Nutr Soil Sci 176:16-18. https://doi. org/10.1002/jpln.201200337

Pypers P, Huybrighs M, Diels J et al (2007) Does the enhanced P acquisition by maize following legumes in a rotation result from improved soil P availability? Soil Biol Biochem 39: 2555-2566. https://doi.org/10.1016/j.soilbio.2007.04.026

Ramos-Zapata JA, Marrufo-Zapata D, Guadarrama P et al (2012) Impact of weed control on arbuscular mycorrhizal fungi in a tropical agroecosystem: a long-term experiment. Mycorrhiza 22:653-661. https://doi.org/10.1007/s00572-012-0443-1

Randhawa PS, Condron LM, Di HJ et al (2005) Effect of green manure addition on soil organic phosphorus mineralisation. Nutr Cycl Agroecosyst 73:181-189. https://doi.org/10.1007 /s10705-005-0593-Z

Rao MA, Violante A, Gianfreda L (2000) Interaction of acid phosphatase with clays, organic molecules and organomineral complexes: kinetics and stability. Soil Biol Biochem 32:1007-1014. https://doi.org/10.1016/S00380717(00)00010-9

Ratnadass A, Fernandes P, Avelino J, Habib R (2012) Plant species diversity for sustainable management of crop pests and diseases in agroecosystems: A review. Agron Sustain Dev 32: 273-303. https://doi.org/10.1007/s13593-011-0022-4

R-Core Team (2013) R: A language and environment for statistical computing. R Foundation for Statistical Computing, Vienna

Reed MS (2008) Stakeholder participation for environmental management: A literature review. Biol Conserv 141:2417-2431. https://doi.org/10.1016/j.biocon.2008.07.014

Rengel Z (2008) Bioavailability of phosphorus and micronutrients in the soil-plant-microbe continuum. Rev Cienc Suelo Nutr Veg 8:84-91. https://doi.org/10.4067/S071827912008000400013

Richardson AE, Simpson RJ (2011) Soil microorganisms mediating phosphorus availability update on microbial phosphorus.
Plant Physiol 156:989-996. https://doi.org/10.1104 /pp. 111.175448

Richardson AE, Lynch JP, Ryan PR et al (2011) Plant and microbial strategies to improve the phosphorus efficiency of agriculture. Plant Soil 349:121-156. https://doi.org/10.1007 /s11104-011-0950-4

Rick TL, Jones CA, Engel RE, Miller PR (2011) Green manure and phosphate rock effects on phosphorus availability in a northern Great Plains dryland organic cropping system. Org Agric 1:81-90. https://doi.org/10.1007/s13165-011-0007-2

Ro S, Becker M, Manske G (2016) Effect of phosphorus management in rice-mungbean rotations on sandy soils of Cambodia. J Plant Nutr Soil Sci 179:481-487. https://doi. org/10.1002/jpln.201600043

Roarty S, Hackett RA, Schmidt O (2017) Earthworm populations in twelve cover crop and weed management combinations. Appl Soil Ecol 114:142-151. https://doi.org/10.1016/j. apsoil.2017.02.001

Roelofs RFR, Rengel Z, Cawthray GR et al (2008) Exudation of carboxylates in Australian Proteaceae: chemical composition. Plant Cell Environ 24:891-904. https://doi. org/10.1046/j.1365-3040.2001.00741.x

Romanyà J, Rovira P (2009) Organic and inorganic P reserves in rain-fed and irrigated calcareous soils under long-term organic and conventional agriculture. Geoderma 151:378-386. https://doi.org/10.1016/j.geoderma.2009.05.009

Romanyà J, Blanco-Moreno JM, Sans FX (2017) Phosphorus mobilization in low-P arable soils may involve soil organic C depletion. Soil Biol Biochem 113:250-259. https://doi. org/10.1016/j.soilbio.2017.06.015

Rose TJ, Damon P, Rengel Z (2010a) Phosphorus-efficient faba bean (Vicia faba L.) genotypes enhance subsequent wheat crop growth in an acid and an alkaline soil. Crop Pasture Sci 61:1009-1016

Rose TJ, Hardiputra B, Rengel Z (2010b) Wheat, canola and grain legume access to soil phosphorus fractions differs in soils with contrasting phosphorus dynamics. Plant Soil 326:159170. https://doi.org/10.1007/s11104-009-9990-4

Rose TJ, van ZL, Claassens A et al (2018) Phytotoxicity of soilborne glyphosate residues is influenced by the method of phosphorus fertiliser application. Plant Soil 422:455-465. https://doi.org/10.1007/s11104-017-3482-8

Rowe DE, Fairbrother TE, Sistani KA (2006) Winter cover crop and management effects on summer and annual nutrient yields. Agron J 98:946-950. https://doi.org/10.2134 /agronj2005.0178

RStudio (2013) RStudio: integrated development for R. RStudio Inc., Boston. http://www.rstudio.com. Accessed 21 Jan 2018

Rückamp D (2011) Role of termites for the distribution patterns of carbon and phosphorus fractions and the genesis of tropical soils, Brazil. PhD-Thesis, University of Bonn

Rutunga V, Karanja NK, Gachene CK (2008) Six month-duration Tephrosia vogelii Hook. f. and Tithonia diversifolia (Hemsl.) A. Gray planted-fallows for improving maize production in Kenya. Biotechnol Agron Soc Environ 12:267-278

Ryan MH, Graham JH (2018) Little evidence that farmers should consider abundance or diversity of arbuscular mycorrhizal fungi when managing crops. New Phytol 1-13. https://doi. org/10.1111/nph.15308 
Sarrantonio M, Gallandt E (2003) The role of cover crops in North American cropping systems. J Crop Prod 8:53-74. https://doi.org/10.1300/J144v08n01_04

Schilling G, Gransee A, Deuhel A et al (1998) Phosphorus availability, root exudates, and microbial activity in the rhizosphere. Z Für Pflanzenernähr Bodenkd 161:465-478. https://doi.org/10.1002/jpln.1998.3581610413

Schipanski ME, Barbercheck M, Douglas MR et al (2014) A framework for evaluating ecosystem services provided by cover crops in agroecosystems. Agric Syst 125:12-22. https://doi.org/10.1016/j.agsy.2013.11.004

Schnug E, De Kok LJ (eds) (2016) Phosphorus in agriculture: $100 \%$ zero. Springer, Dordrecht

Schoumans OF, Chardon WJ, Bechmann ME et al (2014) Mitigation options to reduce phosphorus losses from the agricultural sector and improve surface water quality: A review. Sci Total Environ 468-469:1255-1266. https://doi. org/10.1016/j.scitotenv.2013.08.061

Schüller H (1969) Die CAL-Methode, eine neue Methode zur Bestimmung des pflanzenverfügbaren Phosphates in Böden. Z Für Pflanzenernähr Bodenkd 123:48-63. https://doi.org/10.1002/jpln.19691230106

Scopel E, Triomphe B, Affholder F et al (2013) Conservation agriculture cropping systems in temperate and tropical conditions, performances and impacts. A review. Agron Sustain Dev 33:113-130. https://doi.org/10.1007 /s13593-012-0106-9

Sharpley AN (1995) Soil phosphorus dynamics: agronomic and environmental impacts. Ecol Eng 5:261-279. https://doi. org/10.1016/0925-8574(95)00027-5

Sharpley AN, Smith JR (1991) Effects of cover crops on surface water quality. In: Hargrove WL (ed) West Tennessee Experiment Station April 9-11, 1991. Soil and Water Conservation Society, Jackson

Sharrock RA, Sinclair FL, Gliddon C et al (2004) A global assessment using PCR techniques of mycorrhizal fungal populations colonising Tithonia diversifolia. Mycorrhiza 14: 103-109. https://doi.org/10.1007/s00572-003-0243-8

Sileshi G, Akinnifesi FK, Ajayi OC, Place F (2008) Meta-analysis of maize yield response to woody and herbaceous legumes in sub-Saharan Africa. Plant Soil 307:1-19. https://doi. org/10.1007/s11104-008-9547-y

Simpson RJ, Oberson A, Culvenor RA et al (2011) Strategies and agronomic interventions to improve the phosphorus-use efficiency of farming systems. Plant Soil 349:89-120. https://doi.org/10.1007/s11104-011-0880-1

Smeck NE (1985) Phosphorus dynamics in soils and landscapes. Geoderma 36:185-199. https://doi.org/10.1016/0016-7061 (85)90001-1

Smith SE, Jakobsen I, Gronlund M, Smith FA (2011) Roles of arbuscular mycorrhizas in plant phosphorus nutrition: Interactions between pathways of phosphorus uptake in arbuscular mycorrhizal roots have important implications for understanding and manipulating plant phosphorus acquisition. Plant Physiol 156:1050-1057. https://doi.org/10.1104 /pp.111.174581

Smith A, Fressoli M, Thomas H (2014) Grassroots innovation movements: challenges and contributions. J Clean Prod 63: 114-124. https://doi.org/10.1016/j.jclepro.2012.12.025

Smith SE, Anderson IC, Smith F (2015) Mycorrhizal associations and phosphorus acquisition: From cells to ecosystems. Annu
Plant Rev Phosphorus Metab Plants 48:409-439. https://doi. org/10.1002/9781118958841.ch14

Somado EA, Becker M, Kuehne RF et al (2003) Combined effects of legumes with rock phosphorus on rice in West Africa. Agron J 95:1172-1178. https://doi.org/10.2134/agronj2003.1172

Sorensen JN, Larsen J, Jakobsen I (2005) Mycorrhiza formation and nutrient concentration in leeks (Allium porrum) in relation to previous crop and cover crop management on high $\mathrm{P}$ soils. Plant Soil 273:101-114. https://doi.org/10.1007 /s11104-004-6960-8

Spohn M, Kuzyakov Y (2013a) Distribution of microbial- and root-derived phosphatase activities in the rhizosphere depending on $\mathrm{P}$ availability and $\mathrm{C}$ allocation - Coupling soil zymography with 14C imaging. Soil Biol Biochem 67:106113. https://doi.org/10.1016/j.soilbio.2013.08.015

Spohn M, Kuzyakov Y (2013b) Phosphorus mineralization can be driven by microbial need for carbon. Soil Biol Biochem 61: 69-75. https://doi.org/10.1016/j.soilbio.2013.02.013

Steffens D, Leppin T, Luschin-Ebengreuth N et al (2010) Organic soil phosphorus considerably contributes to plant nutrition but is neglected by routine soil-testing methods. J Plant Nutr Soil Sci 173:765-771. https://doi.org/10.1002 /jpln.201000079

Stewart J, Tiessen H (1987) Dynamics of soil organic phosphorus. Biogeochemistry 4:41-60

Sugito T, Yoshida K, Takebe M et al (2010) Soil microbial biomass phosphorus as an indicator of phosphorus availability in a Gleyic Andosol. Soil Sci Plant Nutr 56:390-398. https://doi.org/10.1111/j.1747-0765.2010.00483.x

Takeda M, Nakamoto T, Miyazawa K et al (2009a) Phosphorus availability and soil biological activity in an Andosol under compost application and winter cover cropping. Appl Soil Ecol 42:86-95. https://doi.org/10.1016/j.apsoil.2009.02.003

Takeda M, Nakamoto T, Miyazawa K, Murayama T (2009b) Phosphorus transformation in a soybean-cropping system in Andosol: effects of winter cover cropping and compost application. Nutr Cycl Agroecosyst 85:287-297. https://doi. org/10.1007/s10705-009-9267-6

Talgre L, Lauringson E, Roostalu H et al (2012) Green manure as a nutrient source for succeeding crops. Plant Soil Environ 58: 275-281

Tanwar SPS, Rao SS, Regar PL et al (2014) Improving water and land use efficiency of fallow-wheat system in shallow Lithic Calciorthid soils of arid region: Introduction of bed planting and rainy season sorghum-legume intercropping. Soil Tillage Res 138:44-55. https://doi.org/10.1016/j.still.2013.12.005

Tarafdar JC, Jungk A (1987) Phosphatase activity in the rhizosphere and its relation to the depletion of soil organic phosphorus. Biol Fertil Soils 3:199-204

Tarawali G, Manyong VM, Carsky RJ et al (1999) Adoption of improved fallows in West Africa: Lessons from mucuna and stylo case studies. Agrofor Syst 47:93-122

Tarui A, Matsumura A, Asakura S et al (2013) Evaluation of mixed cropping of oat and hairy vetch as green manure for succeeding corn production. Plant Prod Sci 16:383-392. https://doi.org/10.1626/pps.16.383

Teboh JM, Franzen DW (2011) Buckwheat (Fagopyrum esculentum Moench) potential to contribute solubilized soil phosphorus to subsequent crops. Commun Soil Sci Plant Anal 42:1544-1550. https://doi.org/10.1080/00103624.2011.581724 
Teles APB, Rodrigues M, Bejarano Herrera WF et al (2017) Do cover crops change the lability of phosphorus in a clayey subtropical soil under different phosphate fertilizers? Soil Use Manag 33:34-44. https://doi.org/10.1111/sum.12327

Tiecher T, dos Santos DR, Calegari A (2012a) Soil organic phosphorus forms under different soil management systems and winter crops, in a long term experiment. Soil Tillage Res 124: 57-67. https://doi.org/10.1016/j.still.2012.05.001

Tiecher T, dos Santos DR, Kaminski J, Calegari A (2012b) Forms of inorganic phosphorus in soil under different long term soil tillage systems and winter crops. Rev Bras Ciênc Solo 36: 271-282. https://doi.org/10.1590/S0100-06832012000100028

Tonitto C, David MB, Drinkwater LE (2006) Replacing bare fallows with cover crops in fertilizer-intensive cropping systems: A meta-analysis of crop yield and $\mathrm{N}$ dynamics. Agric Ecosyst Environ 112:58-72. https://doi.org/10.1016/j. agee.2005.07.003

Trappe JM, Molina R, Castellano M (1984) Reactions of Mycorrhizal Fungi and Mycorrhiza Formation to Pesticides. Annu Rev Phytopathol 22:331-359

Tummers B (2006) DataThief III. https://www.datathief.org/. Accessed 13 July 2017

Turmel MS, Entz MH, Tenuta M et al (2011) The influence of a long-term black medic (Medicago lupulina cv. George) cover crop on arbuscular mycorrhizal fungal colonization and nutrient uptake in flax (Linum usitatissimum) under zero-tillage management. Can J Plant Sci 91:1071-1076. https://doi. org/10.4141/cjps 10115

Turner BL (2007) Inositol phosphates in soil: amounts, forms and significance of the phosphorylated inositol stereoisomers. In: Turner BL, Richardson AE, Mullaney EJ (eds) Inositol phosphates: Linking agriculture and the environment. CABI, Wallingtonford, pp 186-206

Turner BL, Haygarth PM (2005) Phosphatase activity in temperate pasture soils: Potential regulation of labile organic phosphorus turnover by phosphodiesterase activity. Sci Total Environ 344:27-36. https://doi.org/10.1016/j.scitotenv.2005.02.003

Turner BL, Papházy MJ, Haygarth PM, McKelvie ID (2002) Inositol phosphates in the environment. Philos Trans Biol Sci 357:449-469

Turner BL, Cade-Menun BJ, Condron LM, Newman S (2005) Extraction of soil organic phosphorus. Talanta 66:294-306. https://doi.org/10.1016/j.talanta.2004.11.012

Turner BL, Richardson AE, Mullaney EJ (eds) (2007) Inositol phosphates: linking agriculture and the environment. CABI, Wallingford

Turrini A, Sbrana C, Avio L et al (2016) Changes in the composition of native root arbuscular mycorrhizal fungal communities during a short-term cover crop-maize succession. Biol Fertil Soils 52:643-653. https://doi.org/10.1007/s00374-016-1106-8

van der Paauw F (1971) An effective water extraction method for the determination of plant-available soil phosphorus. Plant Soil 34:467-481. https://doi.org/10.1007/BF01372799

Vanden Nest T, Vandecasteele B, Ruysschaert G, Merckx R (2014) Incorporation of catch crop residues does not increase phosphorus leaching: a soil column experiment in unsaturated conditions. Soil Use Manag 30:351-360. https://doi. org/10.1111/sum.12131

Vanlauwe B, Diels J, Sanginga N et al (2000) Utilization of rock phosphate by crops on a representative toposequence in the Northern Guinea savanna zone of Nigeria: response by maize to previous herbaceous legume cropping and rock phosphate treatments. Soil Biol Biochem 32:2079-2090. https://doi. org/10.1016/S0038-0717(00)00150-4

Vanzolini J, Galantini JA, Martínez JM, Suñer L (2017) Changes in soil $\mathrm{pH}$ and phosphorus availability during decomposition of cover crop residues. Arch Agron Soil Sci 63:1864-1874. https://doi.org/10.1080/03650340.2017.1308493

Varela MF, Barraco M, Gili A et al (2017) Biomass decomposition and phosphorus release from residues of cover crops under no-tillage. Agron J 109:317-326. https://doi.org/10.2134 /agronj2016.03.0168

Veneklaas EJ, Stevens J, Cawthray GR et al (2003) Chickpea and white lupin rhizosphere carboxylates vary with soil properties and enhance phosphorus uptake. Plant Soil 248:187-197. https://doi.org/10.1023/A:1022367312851

Villamil MB, Bollero GA, Darmody RG et al (2006) No-till corn/ soybean systems including winter cover crops. Soil Sci Soc Am J 70:1936-1944. https://doi.org/10.2136/sssaj2005.0350

Vos HMJ, Ros MBH, Koopmans GF, van Groenigen JW (2014) Do earthworms affect phosphorus availability to grass? A pot experiment. Soil Biol Biochem 79:34-42. https://doi. org/10.1016/j.soilbio.2014.08.018

Wang B, Qiu Y-L (2006) Phylogenetic distribution and evolution of mycorrhizas in land plants. Mycorrhiza 16:299-363. https://doi.org/10.1007/s00572-005-0033-6

Wang G, Ngouajio M, Warncke DD (2008) Nutrient cycling, weed suppression, and onion yield following brassica and sorghum sudangrass cover crops. HortTechnology 18:68-74

Wang Y, Krogstad T, Clarke JL et al (2016) Rhizosphere organic anions play a minor role in improving crop species' ability to take up residual phosphorus $(\mathrm{P})$ in agricultural soils low in $\mathrm{p}$ availability. Front Plant Sci 7:1-14. https://doi.org/10.3389 /fpls.2016.01664

Weerakoon WL, Seneviratne G, Silva MAPD, Seneviratine AM (1992) Evaluation of Sesbania speciosa as a green manure for lowland rice in the dry zone, Sri Lanka. Plant Soil 145: 131-139. https://doi.org/10.1007/BF00009549

Weil RR (2000) Soil and plant influences on crop response to two African phosphate rocks. Agron J 92:1167-1175. https://doi. org/10.2134/agronj2000.9261167x

Weil R, Kremen A (2007) Thinking across and beyond disciplines to make cover crops pay. J Sci Food Agric 87:551-557. https://doi.org/10.1002/jsfa.2742

Weisskopf L, Abou-Mansour E, Fromin N et al (2006) White lupin has developed a complex strategy to limit microbial degradation of secreted citrate required for phosphate acquisition. Plant Cell Environ 29:919-927. https://doi.org/10.1111 /j.1365-3040.2005.01473.x

Wendling M, Büchi L, Amossé C et al (2016) Influence of root and leaf traits on the uptake of nutrients in cover crops. Plant Soil 409:419-434. https://doi.org/10.1007/s11104-016-2974-2

White CM, Weil RR (2010) Forage radish and cereal rye cover crop effects on mycorrhizal fungus colonization of maize roots. Plant Soil 328:507-521. https://doi.org/10.1007 /s11104-009-0131-x

White CM, Weil RR (2011) Forage radish cover crops increase soil test phosphorus surrounding radish taproot holes. Soil Sci Soc Am J 75:121-130. https://doi.org/10.2136/sssaj2010.0095

Wickham H (2009) ggplot2: elegant graphics for data analysis. Springer, New York 
Wickham H (2011) The split-apply-combine strategy for data analysis. J Stat Softw 40:1-29

Wilke CO (2017) cowplot: streamlined plot theme and plot annotations for "ggplot2", R package version 0.9.3. https:/github. com/wilkelab/cowplot. Accessed 21 Jan 2018

Wortman SE, Drijber RA, Francis CA, Lindquist JL (2013) Arable weeds, cover crops, and tillage drive soil microbial community composition in organic cropping systems. Appl Soil Ecol 72:232-241. https://doi.org/10.1016/j.apsoil.2013.07.014

Yamada T, Kremer RJ, de Camargo e Castro PR, Wood BW (2009) Glyphosate interactions with physiology, nutrition, and diseases of plants: Threat to agricultural sustainability? Eur J Agron 31: 111-113. https://doi.org/10.1016/j.eja.2009.07.004

Zhu Y, Yan F, Zörb C, Schubert S (2005) A link between citrate and proton release by proteoid roots of white lupin (Lupinus albus 1.) grown under phosphorus-deficient conditions? Plant Cell Physiol 46:892-901. https://doi.org/10.1093/pcp/pci094

Zibilske LM, Makus DJ (2009) Black oat cover crop management effects on soil temperature and biological properties on a Mollisol in Texas, USA. Geoderma 149:379-385. https://doi.org/10.1016/j.geoderma.2009.01.001

Zuo Y, Zhang F (2008) Effect of peanut mixed cropping with gramineous species on micronutrient concentrations and iron chlorosis of peanut plants grown in a calcareous soil. Plant Soil 306:23-36. https://doi.org/10.1007/s11104-007-9484-1

Zuo Y, Zhang F, Li X, Cao Y (2000) Studies on the improvement in iron nutrition of peanut by intercropping with maize on a calcareous soil. Plant Soil 220:13-25. https://doi.org/10.1023 /A:1004724219988 